\title{
PAINTINGS IN THE COLLECTION OF HENRY CLAY FRICK
}


Presented by Miss Helen C. Trick April 19al 





\section{Pictures in the Collection}

of Henry Clay Frick, at One East Seventieth Street, New York

New York-Privately Printed 
$N$

$$
\begin{aligned}
& 620 \\
& \text { F6 P5z }
\end{aligned}
$$




\section{Foreword}

HIS little handbook, containing brief descriptive notes of the more important pictures in Mr. Frick's New York residence, is intended merely as an introduction to the Collection, and is in no sense a catalogue. The material for a catalogue has been collected, but it is so comprehensive and voluminous that it cannot be put into a book of any convenient size.

The Frick Collection, as at present constituted, contains over one hundred and eighty paintings. About eighty are in the several rooms of the ground-floor of Mr. Frick's New York residence; and these form the subject of this handbook. Their positions are approximately indicated by letters at the righthand lower corner of the pages of text. Thus GS means Gallery, South; LN, north wall of the Library; DW, west end of the Dining-room; and CE refers to the east side of the Main Corridor.

As far as is permitted by occasional removals to make way for accessions, these illustrated notes follow the order of the paintings on the walls of the different rooms, beginning with the first picture to the left of the door as one enters, thence around the room in the direction followed by the hands of the clock.

The Supplemental List of Paintings, placed next to the illustrated notes, gives the names of the painters and titles of those canvases in other parts of the house which, owing to their location, are not usually shown to visitors. 



\section{Contents}

FOREWORD $\ldots \ldots \ldots \ldots \ldots \ldots \ldots \ldots \ldots \ldots \ldots \ldots \ldots \ldots \ldots$ iii

List of Paintings Described and Illugtrated....... vii-x

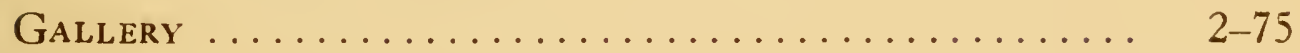

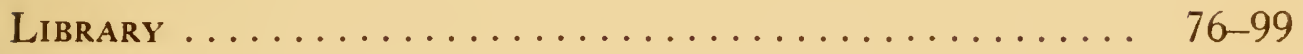

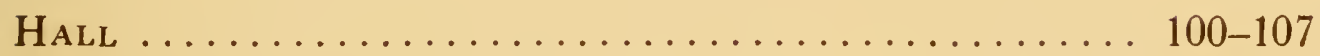

Fragonard Room...................... 108-115

Corridor ............................ 116-123

Dining Room........................ 124-137

Additional .............................. 138.

SUPPI.EMENTAL List . 



\section{List of Paintings Described}

Bellini, Giovanni

St. Francis of Assisi.

"Bronzino," Axgiolo Aliori

Francesco Medici.

Capelle, J. van de

View of Dort...................... 5

Constable, John

Salisbury Cathedral................... 81

Corot, Jean Baptiste

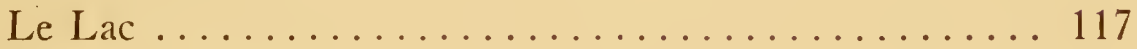

Cuyp, Aelbert

Herdsman and Cors.................. 53

River Scene ..................... 53

Sunrise on the Dort.................... 63

David, Gerard

Descent From the Cross..................... 139

Dyck, Sir Anthony van

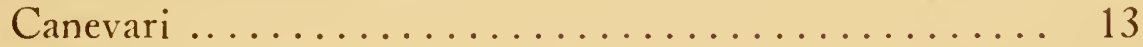

Paula Adorno............................ 17

Marchesa Giovanna Cattaneo................... 19

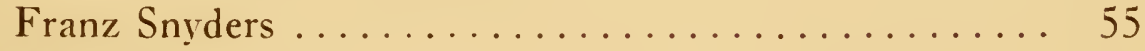

Mrs. Snyders . . . . . . . . . . . . . . 57

Earl and Countess of Derby and Child.......... 59

Fragonard, Jean Honoré

Romance of Love and Youth.............108 to 115

Gainsborough, Thomas

Mrs. Hatchett . . . . . . . . . . . . . . . . . 83

Lady Innes......................... 85

The Hon. Frances Duncombe. . . . . . . . . . . . 127

Goya, Francisco

The Forge....................... 71

Count Teba ....................... 141 
"Greco, El"

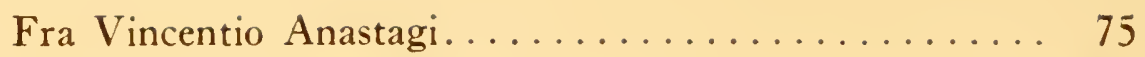

Portrait of a Cardinal................... 105

Purification of the Temple................. 143

Guardi, Francesco

Canal Scene, Venice.................. 39

Grand Canal, Venice.................. 39

Hals, Frans

Portrait of Hinself................... 3

Portrait of a Burgomaster................ 23

Portrait of a Woman.................. 27

Hobbema, Meindert

A Woody Country..................... 15

Landscape with Buildings................ 15

Hogarth, William

Miss Mary Edwards................. 79

Holbein, Hans

Sir Thomas More..................... 103

Sir Thomas Cromwell.................... 107

HOPPNER, JOHN

Miss Byng .......................... 91

The Misses Bligh..................... 125

Lawrence, Sir Thomas

Lady Peel.......................... 87

The Marquise du Blaisel................ 145

Maris, Jacob

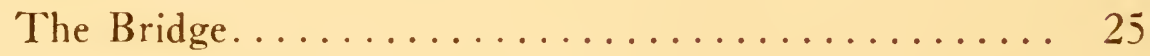

Messina, Antonello da

Deposition from the Cross................ 41

Millet, Jean François

La Femme à la Lampe..................... 121

Murillo, Bartoleme E.

Portrait of Himself.................. 147

Nattier, Jean Marc

Hon. Elizabeth Hamilton................. 149

Ostade, IsaAK van

Halt at the $\operatorname{Inn} \ldots \ldots \ldots \ldots \ldots \ldots \ldots \ldots \ldots \ldots$ 
RaEburn, Sir Henry

James Cruikshank. . . . . . . . . . . . . . . . 65

Mrs. Cruikshank.................... 67

REMBRANDT VAN RyN

Portrait of Himself.................. 45

Polish Rider........................ 47

A Young Painter..................... 49

ReyNolds, Sir JoshuA

Lady Margaret Beaumont.................. 95

Sir George H. Beaumont. . . . . . . . . . . . . . . . . 97

Lady Skipworth...................... 133

Lady Elizabeth Taylor.................. 137

Romney, George

Mary Finch Hatton................. 89

Frances Harford..................... 93

Lady Milnes........................... 129

Countess of Warwick and Children............ 131

Lady Hamilton .................... 151

Rubens, Peter Paul

Portrait of Ambrose de Spinola.............. +3

Ruisdael, Jacob Van

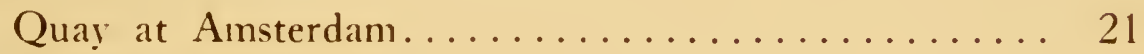

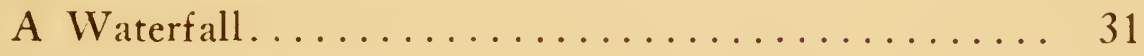

Terborch, Gerard

Portrait of a Lady...................... 9

Titian

Pietro Aretino...................... 7

Man with a Red Cap..................... 69

Turner, J. M. W.

Fishing-boats .................... 77

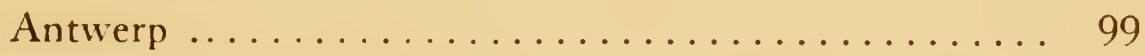

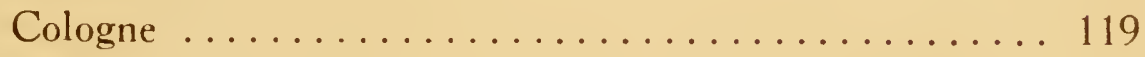

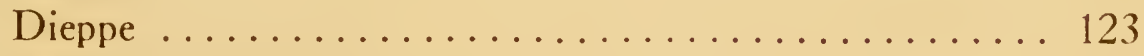

Mortlake Terrace...................... 135

Velaseuez, Diego R.

Philip IV ......................... 73 
VERMEER, JAN

The Music Lesson.................... 51

Soldier and Laughing Girl............... 61 VERONESE, PAUL

Allegory: Virtue and Vice............... 33

Allegory: Wisdom and Strength............. 35

Wouverman, Philip

The Cavalry Camp.................... 29 



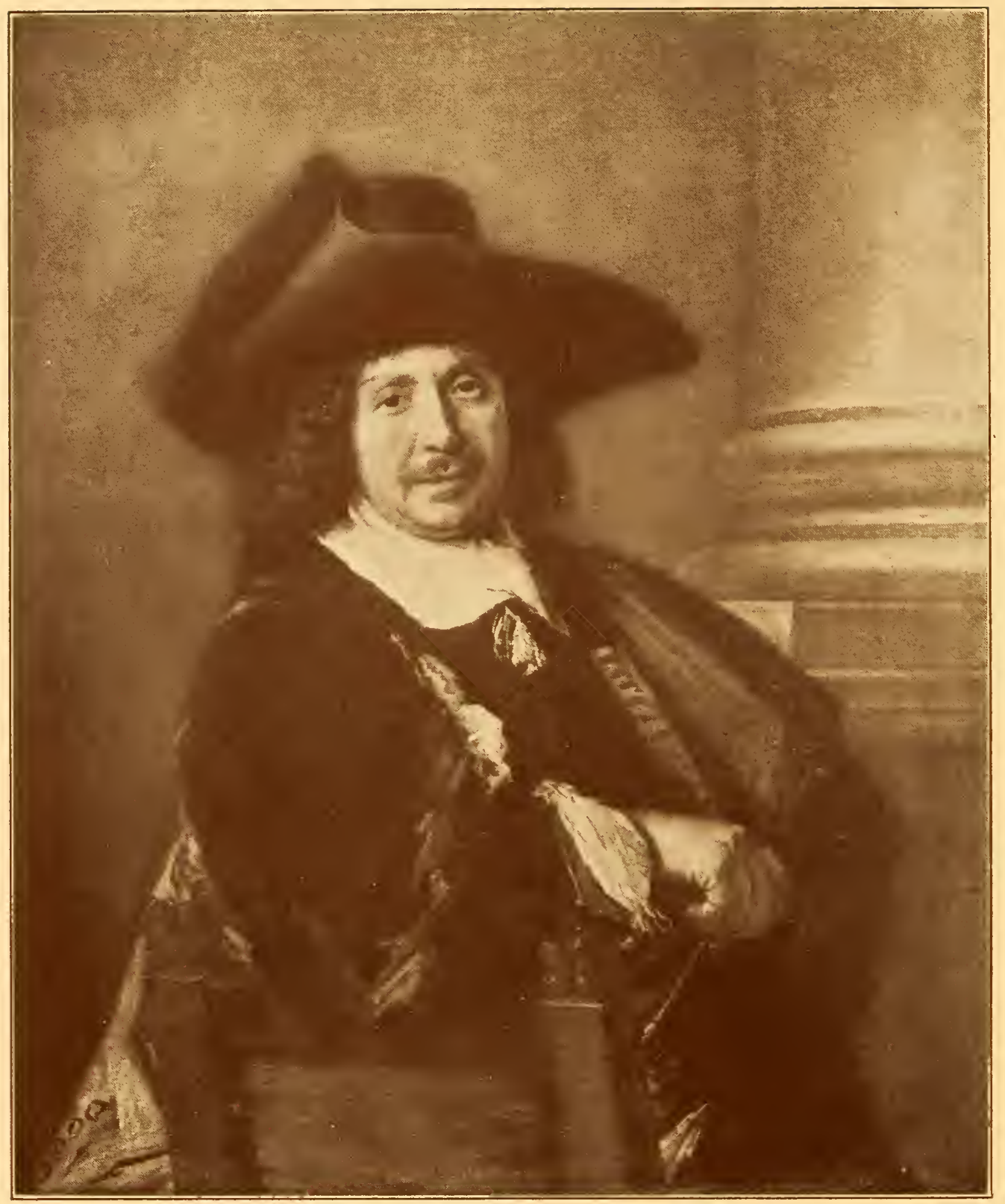




\section{FRANS HALS}

\section{( I 584-I666) \\ PORTRAIT OF HIMSELF}

Canvas, 321/2 inches by $39^{\mathrm{T}} / 2$ inches

7 9 (2) arm on back of chair with a paint brush in hand, 10 large black hat, black dress, wide collar. In Gerald S. Davie's book on Hals, p. I46, it is called a "portrait of the painter."

Signed at the right below the centre, "F. H., I635."

Exhibited at the Burlington House, i 882 , No. 87.

" " "Boston Museum of Fine Arts, I9 Io.

Collection of S. K. Mainwaring, Ottley, England.

Mentioned in "Old Masters' Catalogue," Davies, No. 87 , p. 146.

Mentioned in Moes' "Frans Hals," No. 37, where it is entered as "Portrait de lui-meme."

Comparison of this picture with what are known to be authentic portraits of Hals reveals many resemblances. The face here shows a refinement and a grace that contradict the stories of dissolute living always associated with the name of Hals. This is not the face of a drunkard, nor is the portrait the work of one. Davies, indeed, says that "in his power of setting down the momentary changes which pass across the human face, no man has yet equalled Hals. As a matter of brilliant brush-work and in the consummate power of his handling, he stands second, if second, to Velasquez alone." 


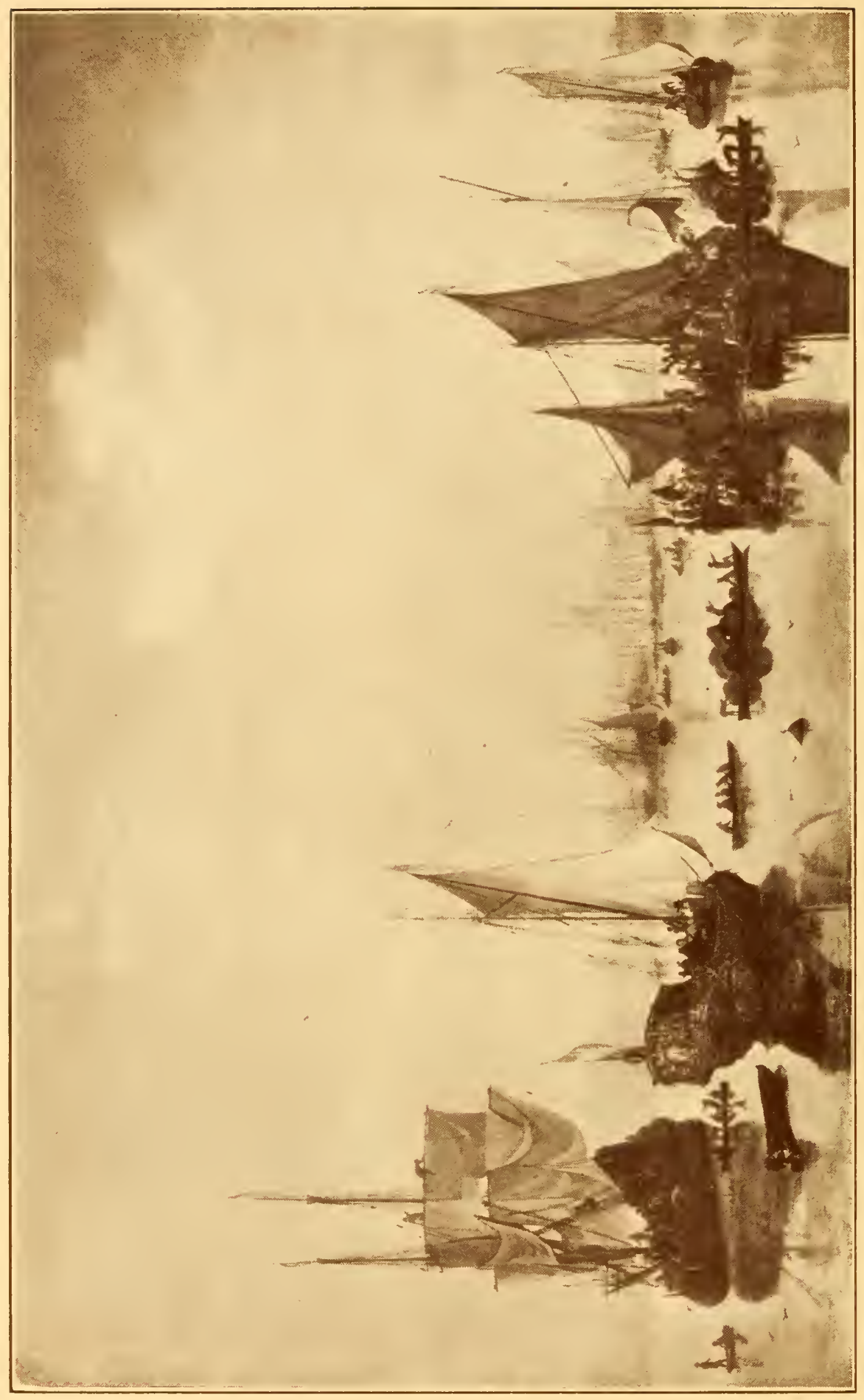




\section{( 1624-5-1679)}

\section{VIEW OF DOR'T}

Panel, 365/8 inches by 61 inches

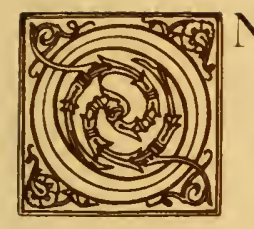

the left is a man-of-war with many figures; closer to spectator, but more to the right, is a State barge with a Dutch flag at the stern. On the right some sail-boats taking on cargo from the row-boats about. In the distance another large man-of-war and many sailingboats; beyond is the City of Amsterdam.

Mentioned in Bryan's Dictionary, Vol. V, p. 232.

Exhibited at Burlington House, I 884, No. 73 .

" " "Boston Museum of Fine Arts, I 9 I o.

" "Old Master Exhibition, M. Knoedler \& Co., I 9I 2 .

Previously owned by Hon. W. Massey Mainwaring, London.

Jan Van de Capelle, born in 1624 or I 625 , son of Francis, a dyer, and Anne Mariens. He married Anne, daughter of Jan van Serhuysen, before Sept. I 2, I 653, and died Sept. 22, I679, leaving four sons and three daughters, and a considerable fortune gained chiefly as a dyer. He had a collection of I 96 paintings and a very large number of drawings. He was himself one of the best seventeenth century painters of seapieces, and also executed several excellent winter landscapes. Examples of his work are to be found in Amsterdam, Berlin, London, Petrograd and Stockholm. 


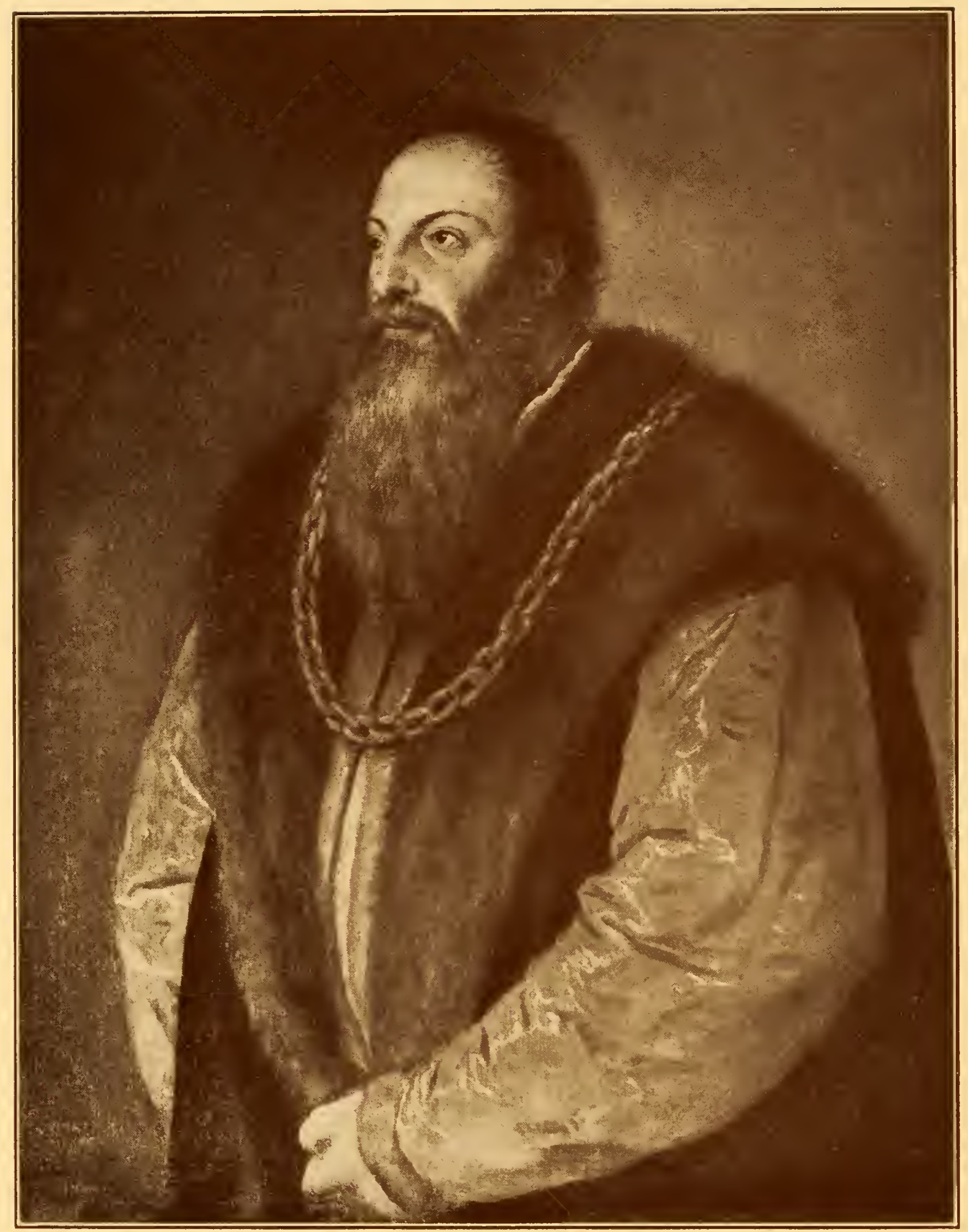




\section{TIZIANO VECELLIO (TITIAN)}

( I 489c.- - 576 )

PORTRAIT OF PIETRO ARETINO

Canvas, 331/2 inches by 39 inches

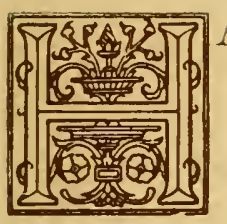

ALF-LENGTH, standing, facing to the right, face almost in profile. Wears a dark colored cloak with broad fur collar, covering a dress the sleeves of which are of a golden brown satin. Around his neck he wears a heavy chain of gold. His beard is long and streaked with gray.

Painted about I 548 .

This intensely interesting figure of the Italian Renaissance was born in Arezzo, in I 492. In his early years he made a living in Perugia as a bookbinder, and picked up an education by reading the books he handled. Later he went to Rome and became a servant in the house of Chigi, the great banker. From the house of Chigi, Aretino passed into the Court of that worldly, high-living, extravagant Pope Leo X., becoming after Leo's death the intimate friend of Giovanni de Medici. In 1527 Aretino was in Venice, the city he loved, and there he lived for twenty-nine years a life of honor, splendor and fame. Titian was one of his intimate table companions, and his great friendship for the artist, says Vasari, who knew them both, was of the greatest advantage, because he made him known far and wide where his pen reached, and especially to princes of importance. In Venice Aretino greatly increased his literary reputation, his work comprising such a wide range as poetry, tragedy, comedy, letters, pornographic and religious writings. He praised the virtues of princes who paid him not to denounce their vices, and it is suggested that when Charles V. paid Aretino more than he paid Titian, he knew what he was about in subsidising a rising power, the power of the press. Justly was he called the "Scourge of princes." Aretino died in 1556 , Titian surviving him twenty years. 


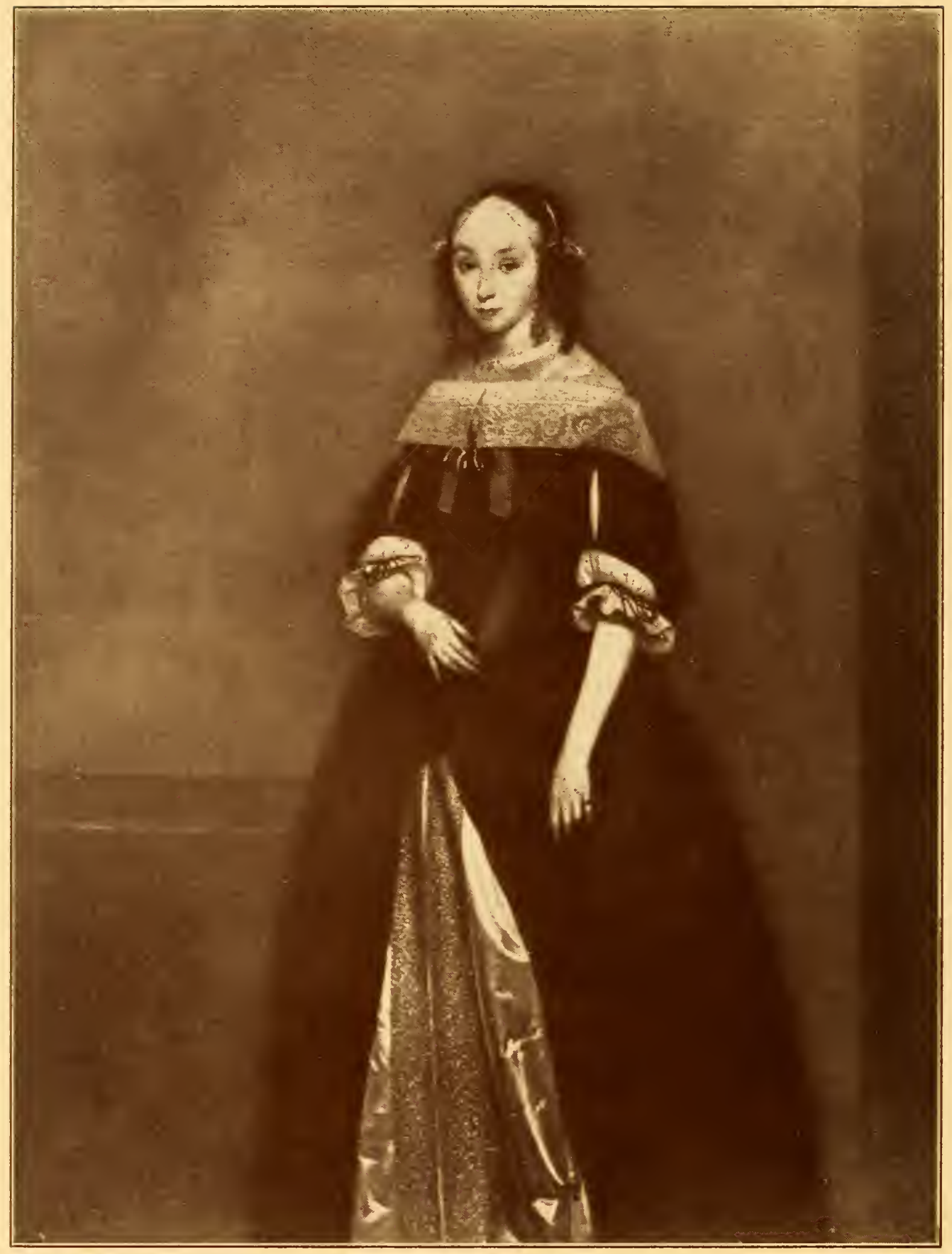




\section{GERARD TERBORCH \\ ( І6г7-г68і) \\ PORTRAIT OF A LADY \\ Canvas, $165 / 8$ inches by $21 \mathrm{~T} / 2$ inches}

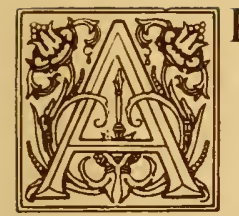

LMOST full length. Facing the spectator. The right hand is held across her person, the left hangs at her side. She wears a black silk dress, opening in front over a white satin skirt trimmed with gold lace. Pearls in her ears. Her hair is drawn tightly back and arranged in ringlets. At the left is a table with a blue cover. In the right background is a door.

Painted about I660-65.

Mentioned in Dr. C. Hofstedes de Groot's "A Catalogue raisonne of the works of the most eminent Dutch painters of the Seventeenth Century," London, I9I3, Vol. V., p. I22, No. 399.

Exhibited at the Hudson-Fulton Celebration, Metropolitan Museum, New York, r909, No. I3 I.

Formerly in the collection of A. Thiem, San Remo.

Terborch more than once painted this model, usually with white satin in her costume, as in the present example. There is a profile portrait of her in the Dresden Gallery, called "A Lady Washing Her Hands." It is possible that the model was his wife, as it is recorded that her jealousy debarred him from using any other female model. 


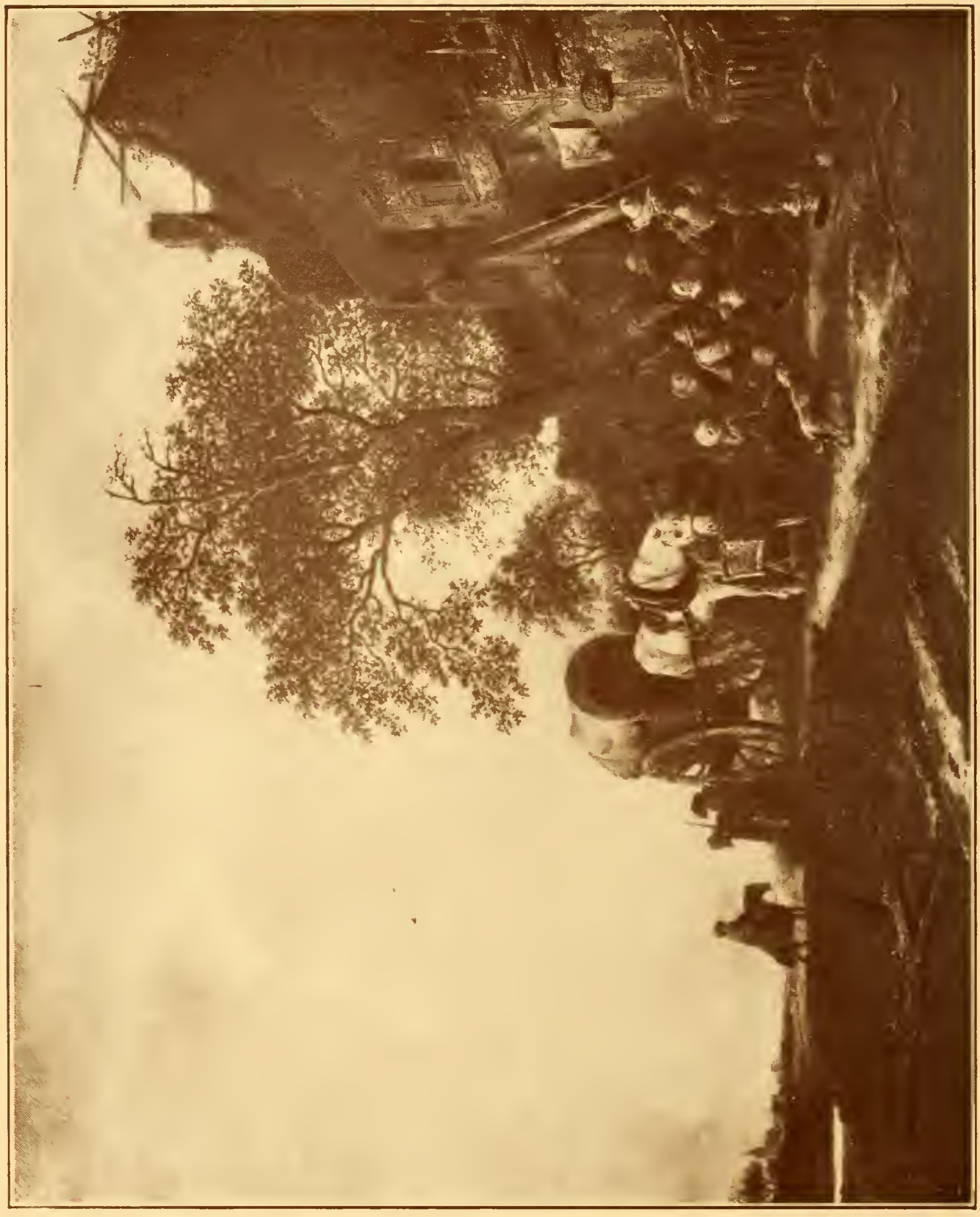




$$
\text { ( I62 I-I649) }
$$

\section{THE HALT AT THE INN}

Panel, 2+1/2 inches by $20 \mathrm{~T} / 4$ inches

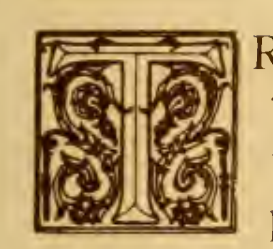
RAVELLERS Halting at an Inn.

"The $\ln$ is on the right. Steps lead up to a balcony. Here a woman stands looking down on a company of from the back and turned half-left, leans against the steps; a dog to left barks at him. To the left of the house is a large tree. To the left of the drinkers is a high two-wheeled tiltcart with a gray horse, which is feeding at a trough. On the left, near the cart, are two men; a rider approaches from the left, where is a view of the distance, with a windmill and a house with a tower. A good and well-preserved picture in a warm brown tone."-Quoted from De Groot.

Signed at the lower right, "Isaac Ostade."

Illustrated in the Burlington Magazine, October, I907, and mentioned in the accompanying article by C. J. Holmes.

Illustrated in the Leuchtenberg Catalogue, No. I 54.

Mentioned in C. Hofstede de Groot's Catalogue of Dutch Painters, Vol. III., p. 447, No. 25.

Previously owned by Duke George of Leuchtenberg, Petrograd.

Exhibited Old Master Exhibition, M. Knoedler \& Co., I 9 I 2. Etched by H. Adam in Muxel's "Leuchtenberg Gallery."

In the Leuchtenberg Gallery, Munich, I 837. I 52 .

In the Leuchtenberg Gallery, Petrograd.

De Groot suggests that this was possibly the canvas sold by Randon de Boisset in Paris, Feb. 3, I777, for 3,645 francs, and by Calonne, Paris, April 21, 1788, for 3,000 francs. 


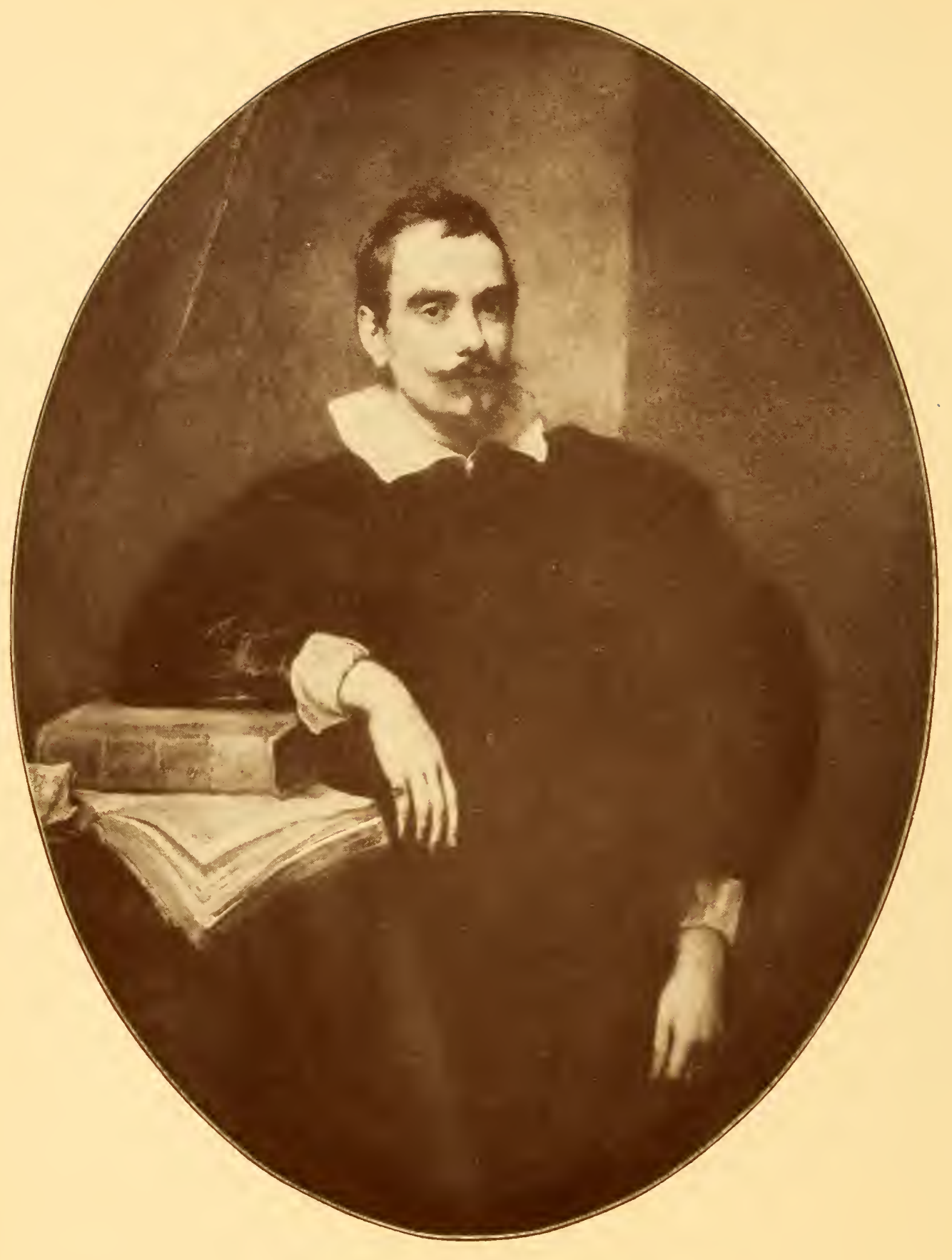




\section{( I 599-I64I) \\ CANEVARI \\ Canvas, 39 inches by 51 inches}

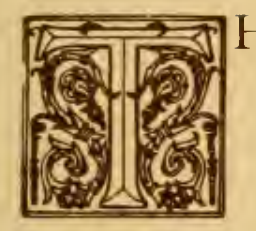

HREE-QUARTER length oval, nearly full face. Standing by the side of a pedestal on which rests a letter and an open book with a closed volume on top of it. Dressed in black with white collar and cuffs, his left arm hangs by his side, while his right rests on a closed volume, on back of which are written the words: "Hippocor Op." The directions on letter disclose the name of the sitter, "Canevari." To the left a red velvet curtain.

Dometrio Canevari, physician, was born at Genoa, in I 559 , and died in Rome, I625. Distinguished both as physician and writer, he published half a dozen scientific works in Latin. Although occupying the dignity of physician-in-ordinary to Pope Urbain VII., he was accused of a sordid avarice that restricted his expenditures to his collection of books, which became celebrated.

The portrait was painted for the Lomellini family and comes from the Cattaneo Palace, Genoa. It was exhibited at the Boston Museum of Fine Arts in I9 Io.

This is one of the famous paintings by Van Dyck which hung for generations in the Cattaneo Palace. The Italian Government sought to prevent their removal from Italy, but found that this collection was exempt from the operation of the law which forbade the exportation of works of art. 


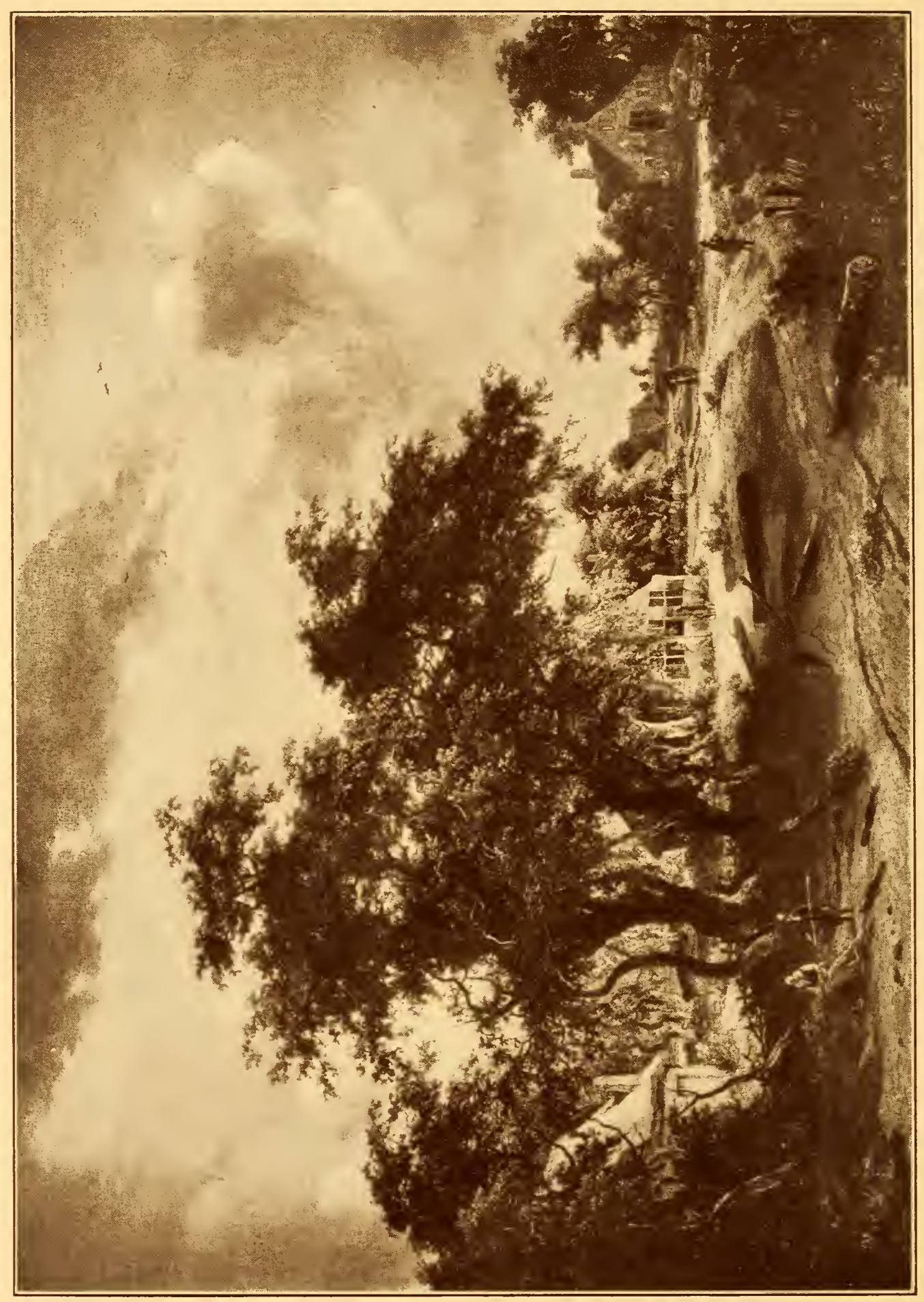




\section{MEINDERT HOBBEMA}

\section{(1638-1709)}

\section{LANDSCAPE WITH BUILDING AND FIGURES}

\section{Canvas, 51 I $/ 8$ inches by 37 inches}

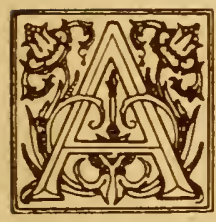

WATERMILL and cottages. This admirable picture exhibits a view of some rural hamlet in Holland. On the right are luxuriant clusters of umbrageous trees, between which may be discerned an overshot watermill; a cottage, of a picturesque appearance, embowered in trees, occupies the centre of the view, the inhabitant of which stands at the half-door, conversing with a villager. Within the shade of overhanging trees on the left is a second cottage with a thatched roof. A high road from the front divides the scene, and leads to the distant landscape. The picture is further identified by a man and a boy standing in conversation with a traveller seated by the roadside, and a man in a scarlet jacket near a pool of water on the right. The brilliancy of a summer's afternoon completes the charm of the scene."-Quoted from Smith's Catalogue Raisonné.

Formerly owned by the Earl of Burlington.

\section{A VIEW OF A WOODY COUNTRY}

Panel, $+3 \frac{\mathrm{T} / 2}{2}$ inches by 30 inches

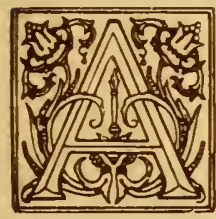

IVOODY country, interspersed with houses, forming apparently a straggling village. A large clump of trees is on the right and beyond it is a cottage, in front of which are a man and a boy, and still more remote are other cottages, some of which are partly concealed by trees. On the foreground of a road which intersects the whole scene, are two men and a woman; one of the former, wearing a red jacket, is seated, and the other carries a piece of timber; near the latter is a traveller sitting on a $\log$. Formerly in the Blathwayt Collection. 


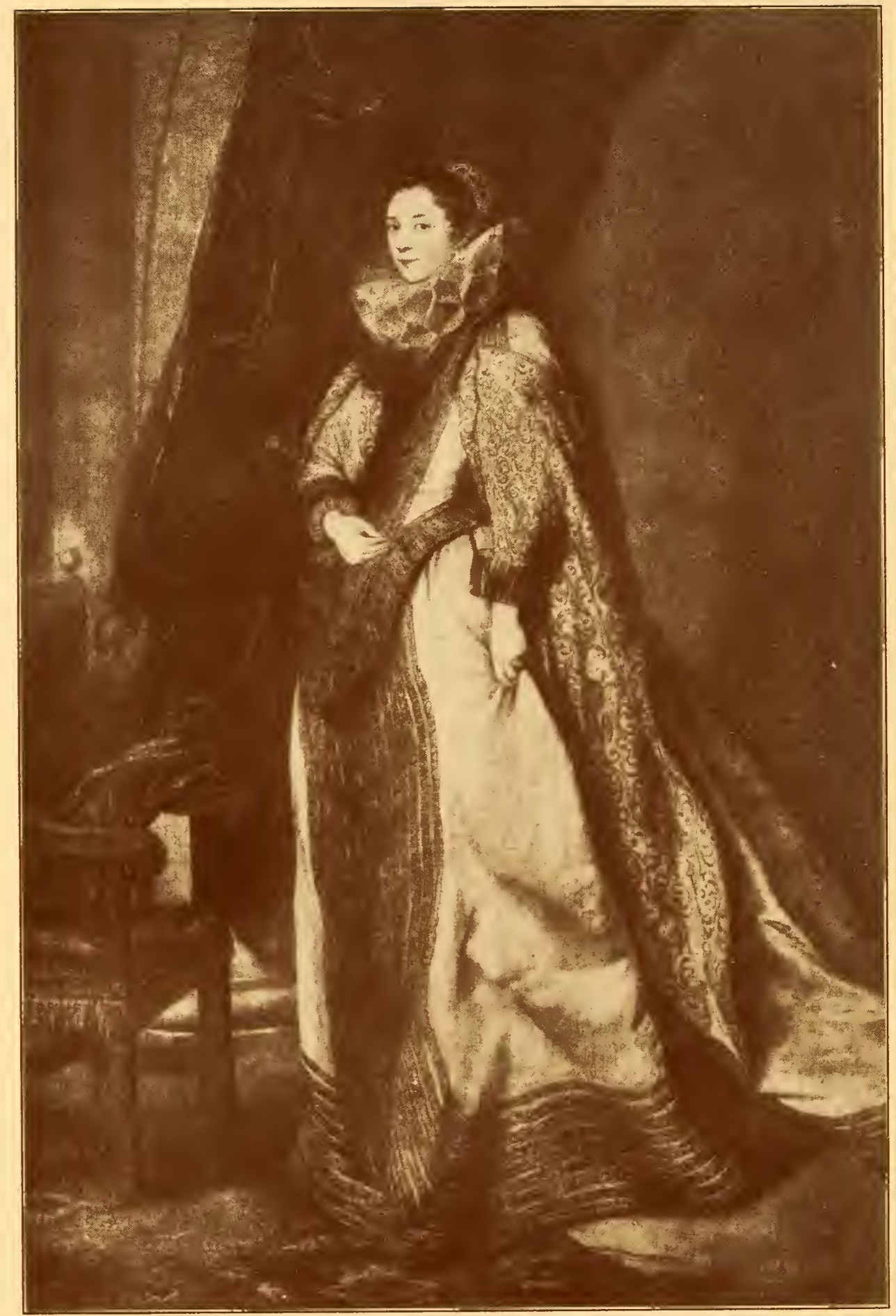




\section{SIR ANTHONY VAN DYCK}

( I 599-164I)

\section{PAOLA ADORNO, MARCHESA DI BRIGNOLA-SALA}

Canvas, 6o inches by 92 inches

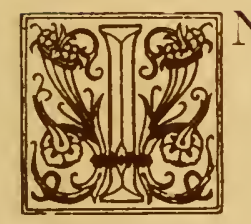

The midst of a richly furnished room, in soft, warm tones of grey, stands the Marquise Pauline, a small, slender woman with an exceptionally small head and short arms; her reddish hair is dressed in the then prevailing style, and she wears a network of pearls at the back of her head. The stiff white satin bodice adds somewhat to the length of her body, the skirt hanging down at the back in long, graceful folds. She looks sideways with widely opened eyes, somewhat severe, perhaps, but captivating. Her small, but imperious, mouth is closed, giving her a rather commanding air. One hand rests against her stomacher, while with the other she lightly grasps the folds of her robe. She rules in her house, she is a queen of beauty, and shows plainly that she is aware of it. . . . It is the apotheosis of a pretty woman, the red draperies, all blend together, making a symphonious whole. It is just possible that the varnish has added to the amber tint which predominates over the whole; but under whatever conditions of tint or color, the little Marquise is a vision of beauty and elegance.

By birth the Marquise was an Adorno, daughter of Giambattista Adorno and of his first wife, Paola di Giacomo Spinola. Her father was Governor of Genoa from i62 I till I632. She married Anton Guilio di Gianfrancesco Brignole, son of a Doge of Genoa and Ambassador to Philip IV. of Spain.

"Contemporary gossip, crystallized into tradition, suggests an undue influence exercised by the chivalrous young painter on the heart of the fair Marchesa. Happy lady, happy painter, even if the link between them were not one of love, that they should both be rendered immortal by the same magic touch of art!"-Lionel Cust, "Anthony Van Dyck," p. 40. 


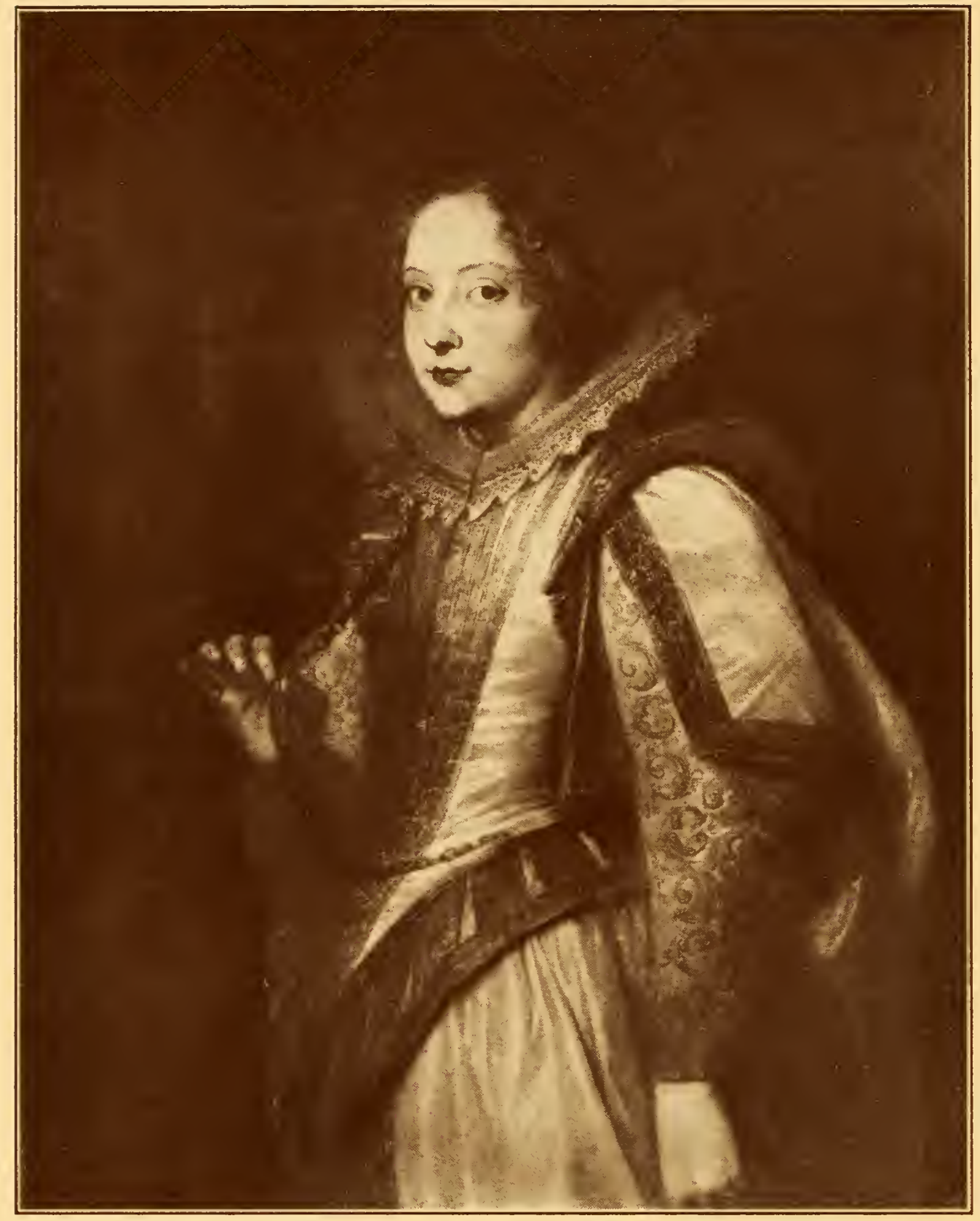




\section{SIR ANTHONY VAN DYCK \\ ( I 599-I64I) \\ MARCHESA GIOVANNA CATTANEO}

Canvas, 34 inches by $403 / 8$ inches

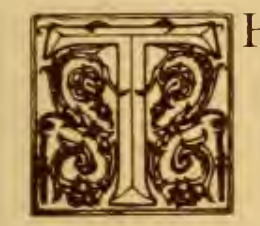

HREE-QUARTER length, nearly full face, standing; wears a white satin dress trimmed with gold braid. Around her neck she wears a stiff linen collar edged with lace. In her right hand she holds between her forefinger and thumb a heavy gold chain suspended from the neck. Her left hand hangs by her side. A cap covers the back of her head.

This portrait, which was painted about 1625 , is that of the daughter of Marchese and Marchesa Giovanni Battista Cattaneo. The portraits of these latter two were purchased for the National Gallery of London, in I908. They all came from the Cattaneo Palace, Genoa, and their removal created a great sensation in the art world. It is referred to in the Encyclopedia Britannica.

This portrait is mentioned by Haldane Macfall in his History of Painting, "The Flemish Genius," and by C. J. Holmes, in the Burlington Magazine, XIII, 306-I6 (plate XIII, 37I). It is also described by $\mathrm{Vm}$. Walton and Lionel Cust in Burlington Magazine, XVI, 300-302. It was exhibited at the Boston Museum of Fine Arts, in 19 I 0. 


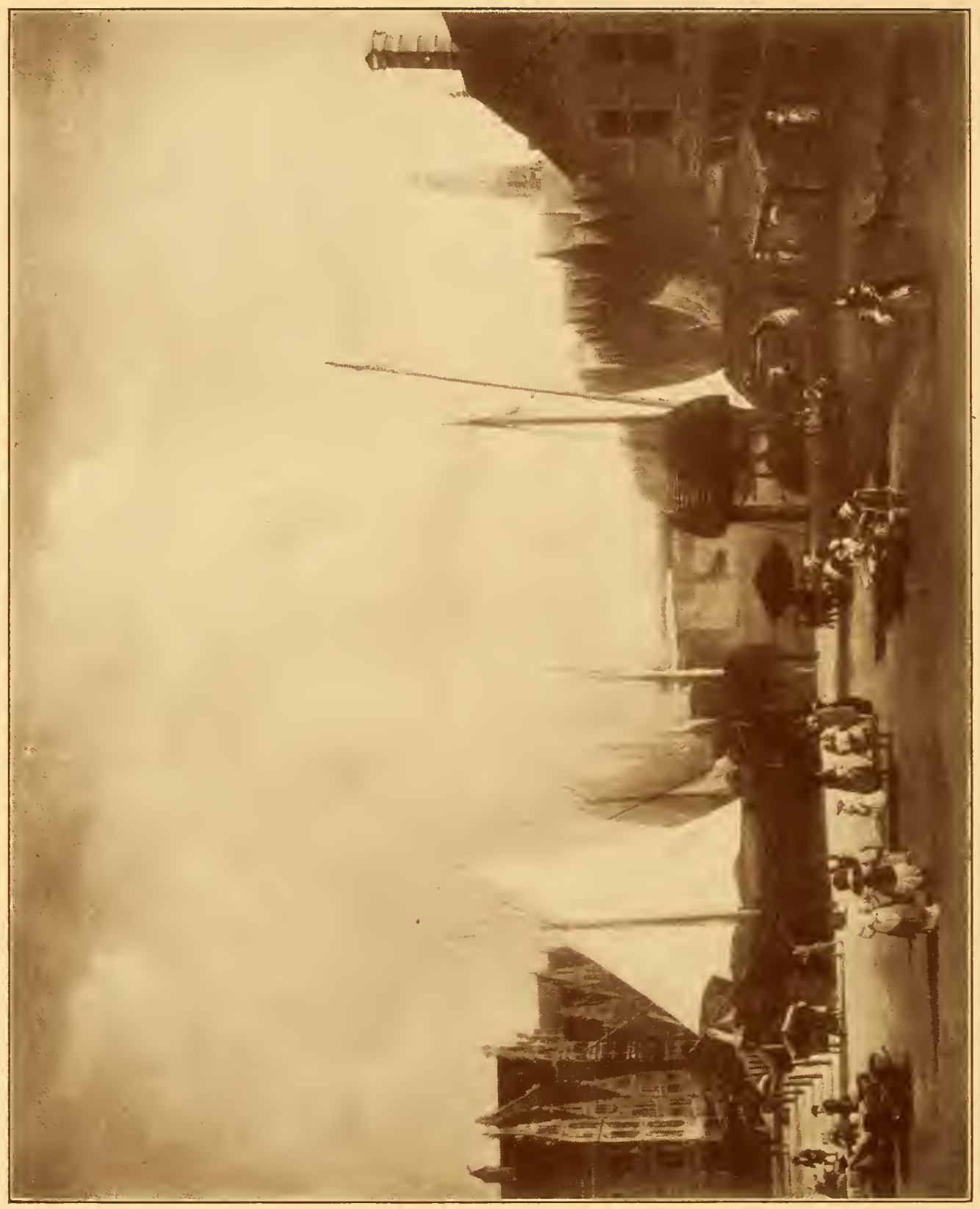




\section{JACOB VAN RUISDAEL \\ ( I628-1682)}

\section{THE QUAY AT AMSTERDAM}

\section{Canvas, $21 \% 2$ inches by 26 inches}

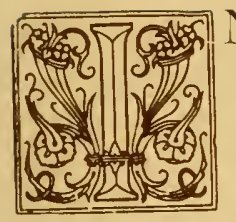

the foreground is the Dam; on the right is the Weigh-house, half cut off by the frame. The broad canal called the Damrak is in the centre, with the Papenbrug crossing it in the background. On both sides are rows of houses; above them, to the right, rises the tower of the Oude Kerk. In the square in front ladies and gentlemen walk up and down. Sailing ships lie at the Quay to right and left; white sails are seen in the distance above the bridge. Blue sky with clouds.

Signed at the bottom right-hand corner.

From the Maurice Kann Collection.

Exhibited at the Boston Museum of Fine Arts, I9 Io.

Etched by Rouveyre.

Sale, Baron de Beuronville, Paris, May 9, i 88 I, No. 450.

In the possession of the Paris dealer, C. Seidelmeyer, "Catalogue of 300 Paintings," I 898 , No. I 82.

Mentioned by de Groote, Catalogue of Dutch Painters, IV, p. IO.

"Jacob vain Ruisdael was destined to be the greatest exponent of landscape art, the master at whose feet all posterity have sat for guidance and inspiration, through whom Constable became the bright glory of English landscape painting, as Constable again let his mantle fall on the Barbizon group, of whom the men of to-day have been disciples. But Ruisdael was the first. As Rembrandt by a Hash of his will brought forth the glory of chiaroscuro, so Ruisdael was the first to interpret the harmonious chords, major and minor, of nature's symphony, and infuse his own soul subjectively into the interpretation."Preyer's Art of the Netherland Galleries. 


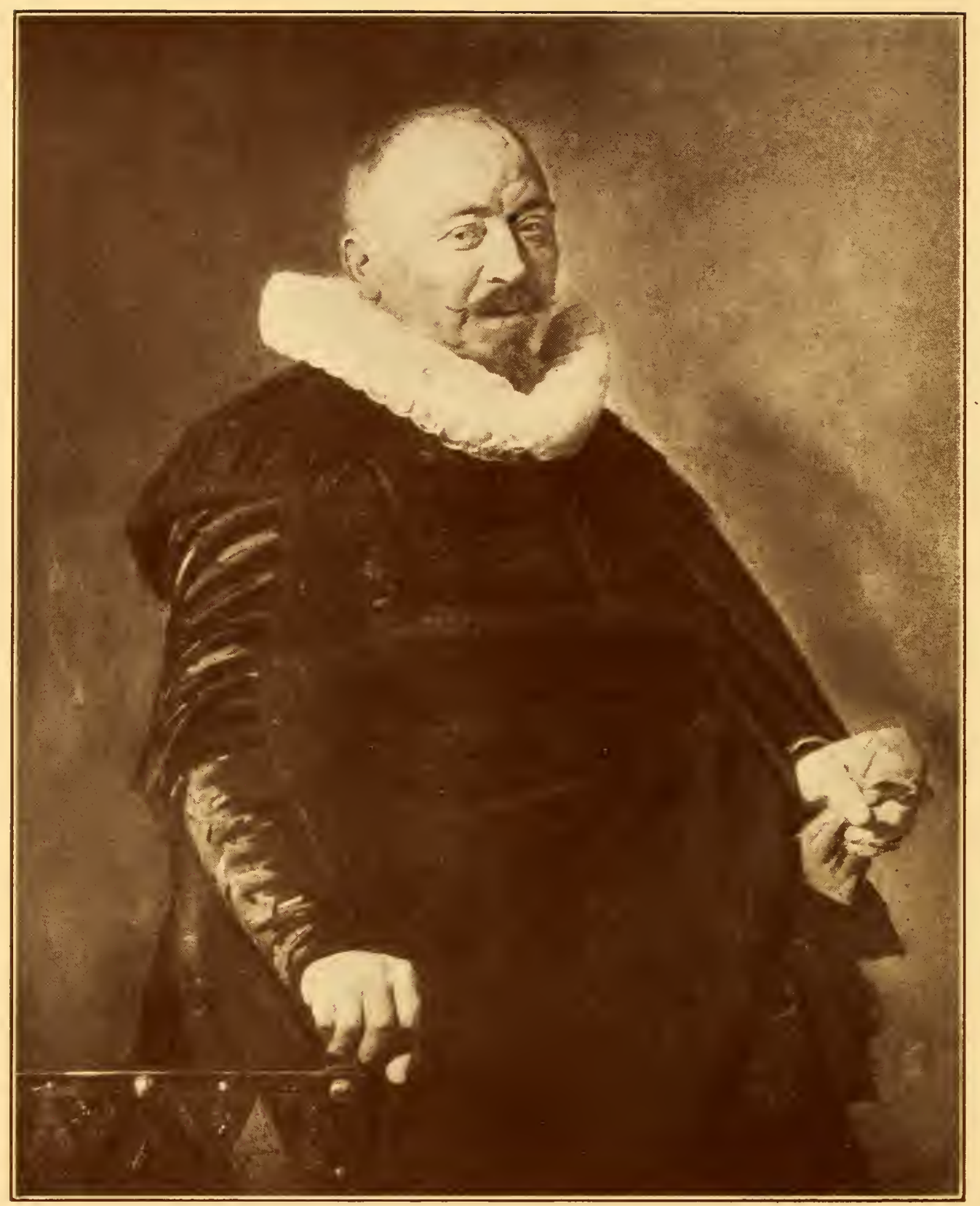




\section{FRANS HALS}

\section{( I $584-1666)$ \\ PORTRAIT OF A BURGOMASTER}

Canvas, $45^{\mathrm{T}} / 2$ inches by 36 inches

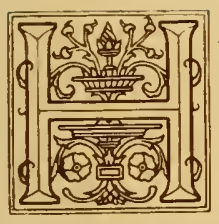

ALF-LENGTH. He faces three-quarters right, and looks down to the left, past the spectator. His right hand grasps an ornament on the back of a chair; his left hand holds a pair of gloves. He has grey hair, a grey moustache, and pointed beard. He wears a black velvet coat, a big cloak falling from the left shoulder to the right hip, and a large white frilled collar. Painted about I 627 .

From the collection of the Earl of Arundel.

$$
\text { " " " "M. Maurice Kann, Paris. }
$$

In the possession of the Paris dealer, C. Sedelmeyer, "Catalogue of I oo Paintings," I 895. No. I 3.

Exhibited at the Boston Museum of Fine Arts, I9 Io.

" " "National Loan Collection, London, I 909.

Mentioned in Les Arts, April, I909.

" " de Groot's Catalogue of Dutch Painters.

"The vitality, the frankly human side of Hals' portraits, strikes us because the character of his sitters has been apparently recognized without searching, keenly caught on the selfrevealing instant, and transmitted to the canvas so that it pulsates with life-life itself. Yet no vulgar trickery for illusionary deceit-anything but that. His work is frankly painting. His portrait is a painted man or woman. But herein becomes Hals the superior of all rivals, the inimitable marvel that, while we see his broad dabs and dashes and count the strokes that go to make mustachios or beard-still the person appears in his ego, with the laugh or smile that reveals the soul."-Preyer's "Art of the Netherland Galleries," pp. 43-46. 


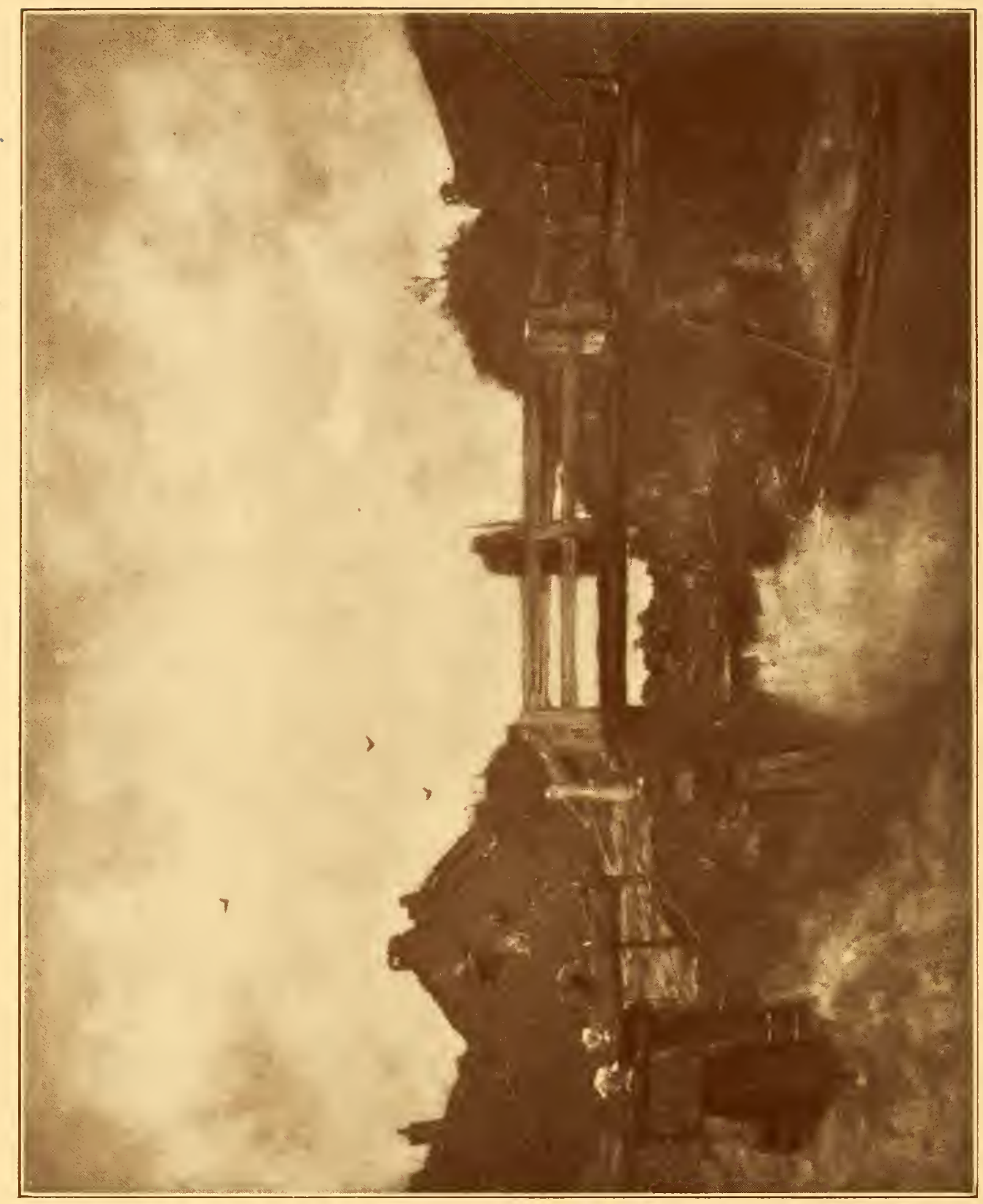




\section{JACOB MARIS \\ (1837-1899)}

THE BRIDGE

Canvas, 543/4 inches by $44^{\mathrm{T}} / 2$ inches

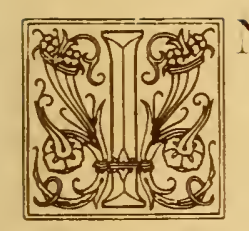

the immediate foreground a canal crossed by a bridge on which stands a woman. Below and close to the spectator a man in a barge engaged in lighting his pipe. To the left a gently inclined road along which walk two peasant women in single file carrying yokes from which milk-cans are suspended. Houses beyond bridge to right and left, town in the distance. Gray sky.

Signed at the lower right, "J. Maris." Painted in 1885.

The International Studio of February, I907, speaks as follows of this picture:- "The largest and most important Maris in the collection (i.e., Alexander Young's) is 'The Bridge,' a work treated in the artist's broadest and most vigorous style. The composition and decorative qualities which are seen here are only surpassed by the masterly brushwork and the truthfulness of the atmospheric effect."

Illustrated in "Nineteenth Century Art," by D. S. MacColl, between pp. 84 and 85 .

An etching of this painting by Phillip Zilcken was published in I887. Reproduced in "The Brothers Maris" (Summer number of the Studio), London, 1907, plate p. 20, and mentioned pp. I 5, I 6, 24, 29, 33 .

Exhibited at the Glasgow International Exhibition, I90I, No. I 370 .

Exhibited at the Guildhall, London, 1903, No. 92.

Collection of J. S. Forbes, London.

" " Alexander Young, London. 


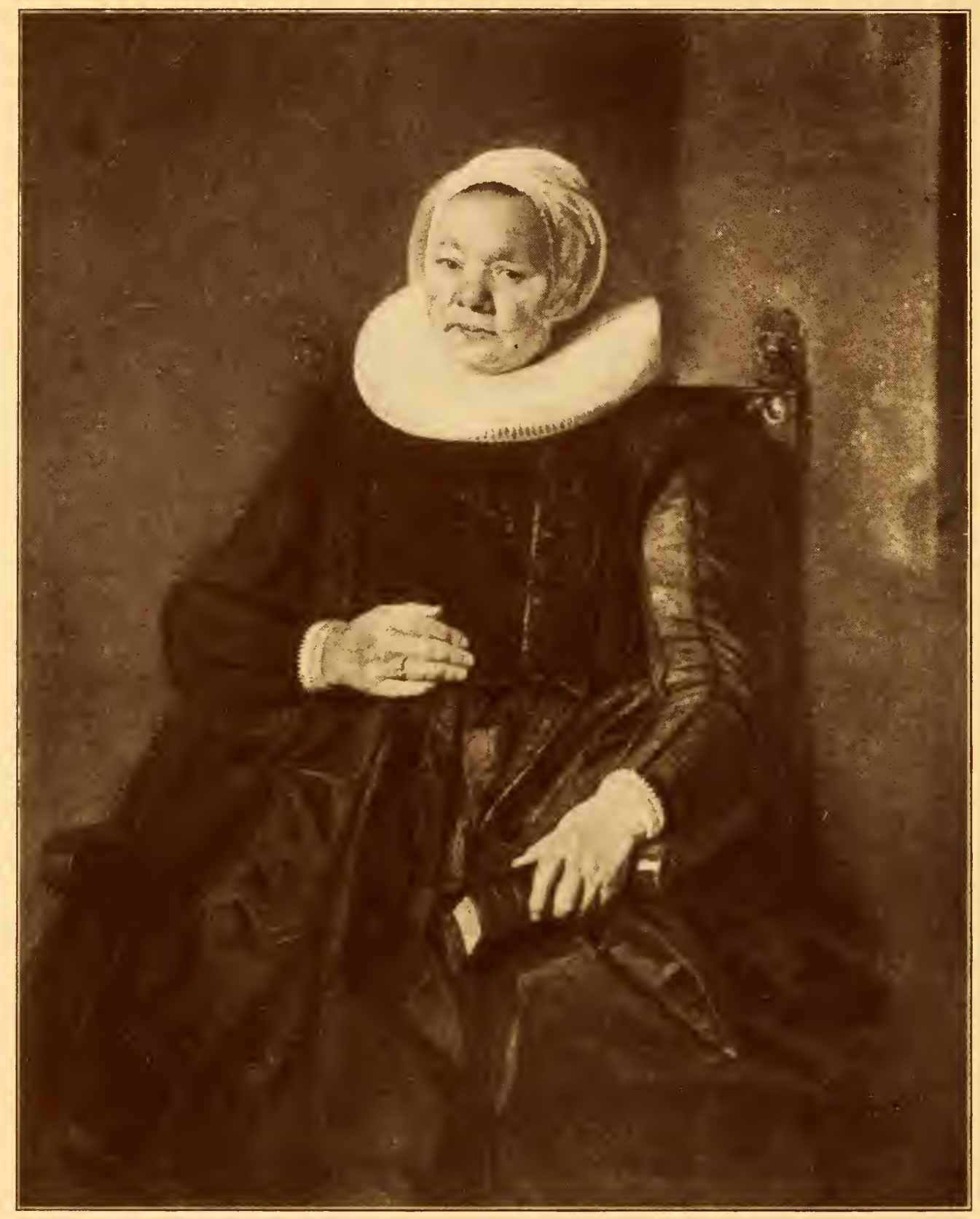




\section{FRANS HALS}

$$
\text { ( I584-1666) }
$$

\section{PORTRAIT OF A WOMAN}

Canvas $363 / 4$ inches by 45 inches

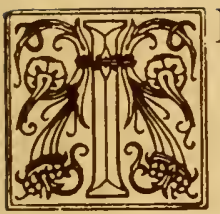

HREE-QUARTER length; seated; turned half way to the left; nearly full face; looking at the spectator; left forearm resting on arm of chair; the hand holding book; the right hand in front; dressed in black with cap and ruff; grey background.

Inscribed on the left, at top "Aetat suae 56 ANO. I6 $35 . "$

Mentioned in E. IW. Moes' work on Frans Hals.

“ " de Groot's Catalogue of Dutch Painters.

Exhibited at Burlington House, I 885 , No. I05.

" "Cent. chefs d'CEuvre, I 892.

Collection of J. Bernard, Amsterdam, I 834 .

" " de Vries.

“ " " D. P. Sellar, London, I 889.

" " Charles Shiff, Paris, I 893.

" "Charles T. Yerkes, New York, igro.

"While Rembrandt surpassed Hals only in one respect-in the romanticism of his life-effects-Hals was his equal in every quality which goes to make a master of masters. No man has ever surpassed the Haarlem genius as a technician. The manner of painting, like execution in music, is of the greatest importance. The manner of Hals was bold, imperial, its power subdued and graded according to the importance of the parts; but above all of an ease and assurance, without correction or emendation, that verges on the miraculous. There was progress even in his magical touch, whereby the sparkling virtuosity of his earlier years developed toward greater refinement, harmony, and sobriety in his latest paintings, expressing himself ever more concisely and yet more clearly."-Quoted from Preyer. 


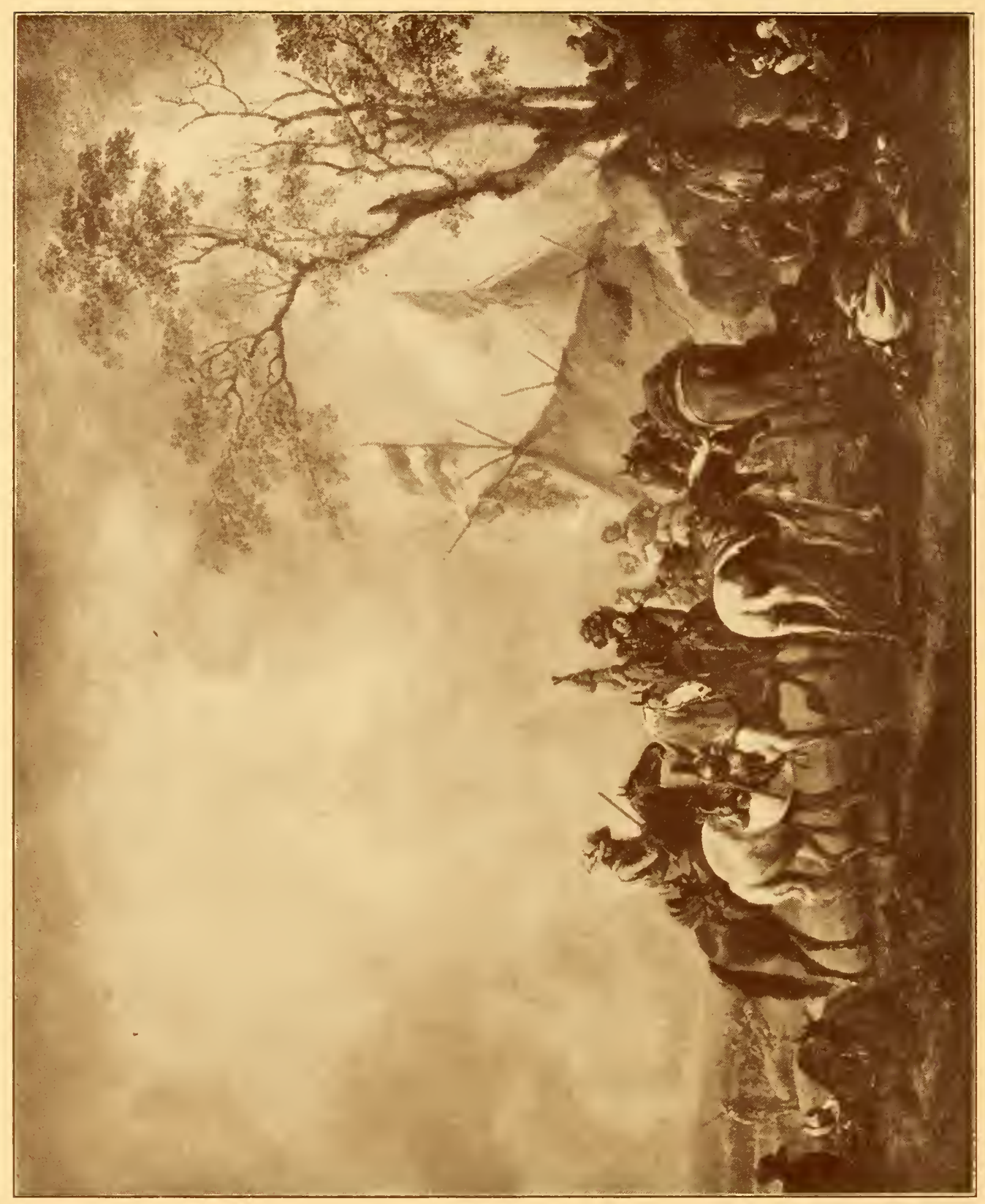




\section{PHILIP WOUVERMAN}

\section{( I6I9-I688) \\ THE CAVALRY CAMP \\ Panel, 203/4 inches by $16 \mathrm{I} / 4$ inches}

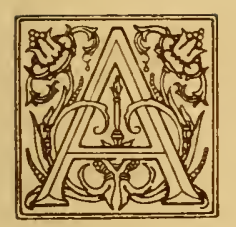

LANDSCAPE with a group of seven cavalry horses near some tents, erected near a tree on the right, from which two flags are Hying; the four farthest mounted, that in the middle by a trumpeter; in the right corner five soldiers around a fire, one of them stands with his back toward it, and another is lying asleep on the ground."-Quoted from Smith's Catalogue Raisonné. Signed at lower left, "P.W."

Engraved by Moyreau, No. 45, about I742, when in M. Dinet's Collection.

Collection of M. Dinet, I 742 .

"Van Loon, Amsterdam, I 827.

"Bosch, Vienna, I 885 .

Philip Wouverman was baptized at Haarlem, May 24, r6r9. He was the son of Paulus Joosten Wouverman, also a painter, whose works, however, have not come down to us. $\mathrm{He}$ is said to have received his first lessons from his father. Then he became a pupil of Frans Hals, according to the creditable statement of De Bie. Finally, he is said to have perfected himself in his favorite study under the direction of Pieter Verbeeck of Haarlem, a painter of horses. Little is known of his life. He died in I688. Dr. Bode calls him "one of the ablest and most original painters of the whole Dutch school." Sir Walter Armstrong says "His popular reputation depends chiefly on his horses, but in his finest works he shows himself a consummate master of composition, of aerial perspective, and of artistic anatomy. As a natural colorist, too, and as a technical painter, he has few equals." 


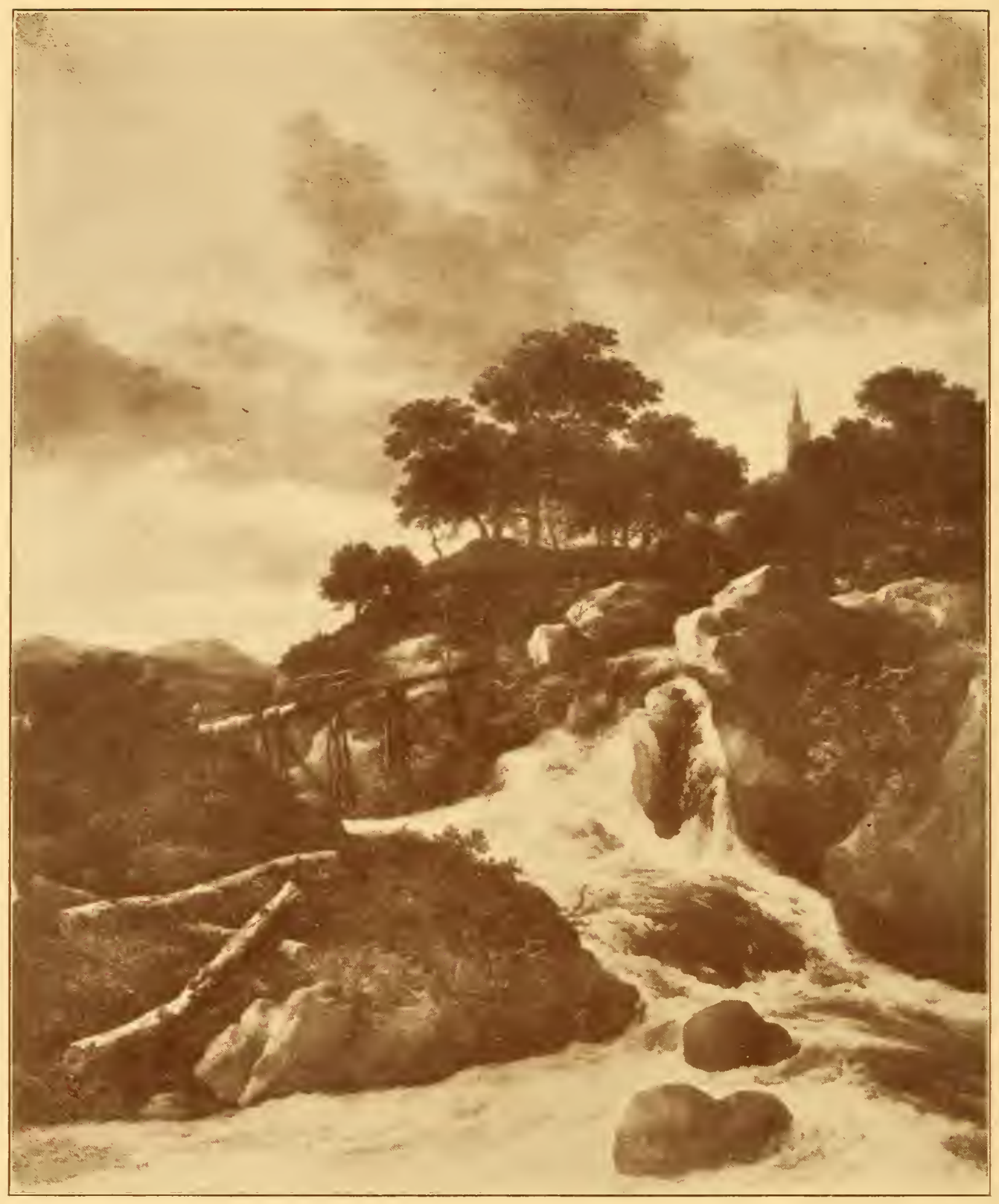




\section{JACOB VAN RUISDAEL}

( I628-1682)

\section{A WATER FALL}

Canvas, $33^{\mathrm{T}} / 2$ inches by $39^{1} / 2$ inches

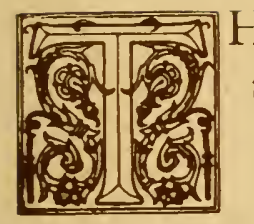

HE composition of this superb picture exhibits, on the left, a lofty rocky hill, partly covered with verdure, and crowned with a cluster of trees of varied foliage, above the tops of which appears the spire of a neighbouring village church; through a ravine in the same hill rushes a volume of water, which falls in a foaming cataract into a channel beneath, along which it rolls in rapid eddies towards the left, and gurgles amidst stones over a great portion of the foreground. A high bank of broken fern, on which lie the trunks of three trees, makes the boundary of the stream on the right; from hence the eye is conducted to a rustic bridge, over which a shepherd is driving a flock of sheep. The aspect is that of a fine day, and it is impossible to commend too highly this beautiful production of art, for nothing ever came from the pencil of the painter more faithful to nature, or more perfect in its mechanism and general arrangement."-Quoted from Smith's Catalogue Raisonné.

Signed below on the rock, "J. Ruisdael."

Formerly in the collections of Baron Lockhorst, John Smith, author of the Catalogue Raisonné, and the Earl of Onslow.

"After having given marvellous views of his own country, Ruisdael commenced in desperation to produce those wild scenes of mountain torrents dashing over rocks, with which his master, van Everdingen, had struck the popular fancy. A trip to the northern forests of Germany gave him his material. Although his work of this kind is superior to that of Hobbema, he still remained unappreciated, and he came to want. The members of the Mennonite community of Amsterdam, of which sect he was a member, secured admission for him in the almshouse of Haarlem in I68 I, where he died the following year."-Preyer. 


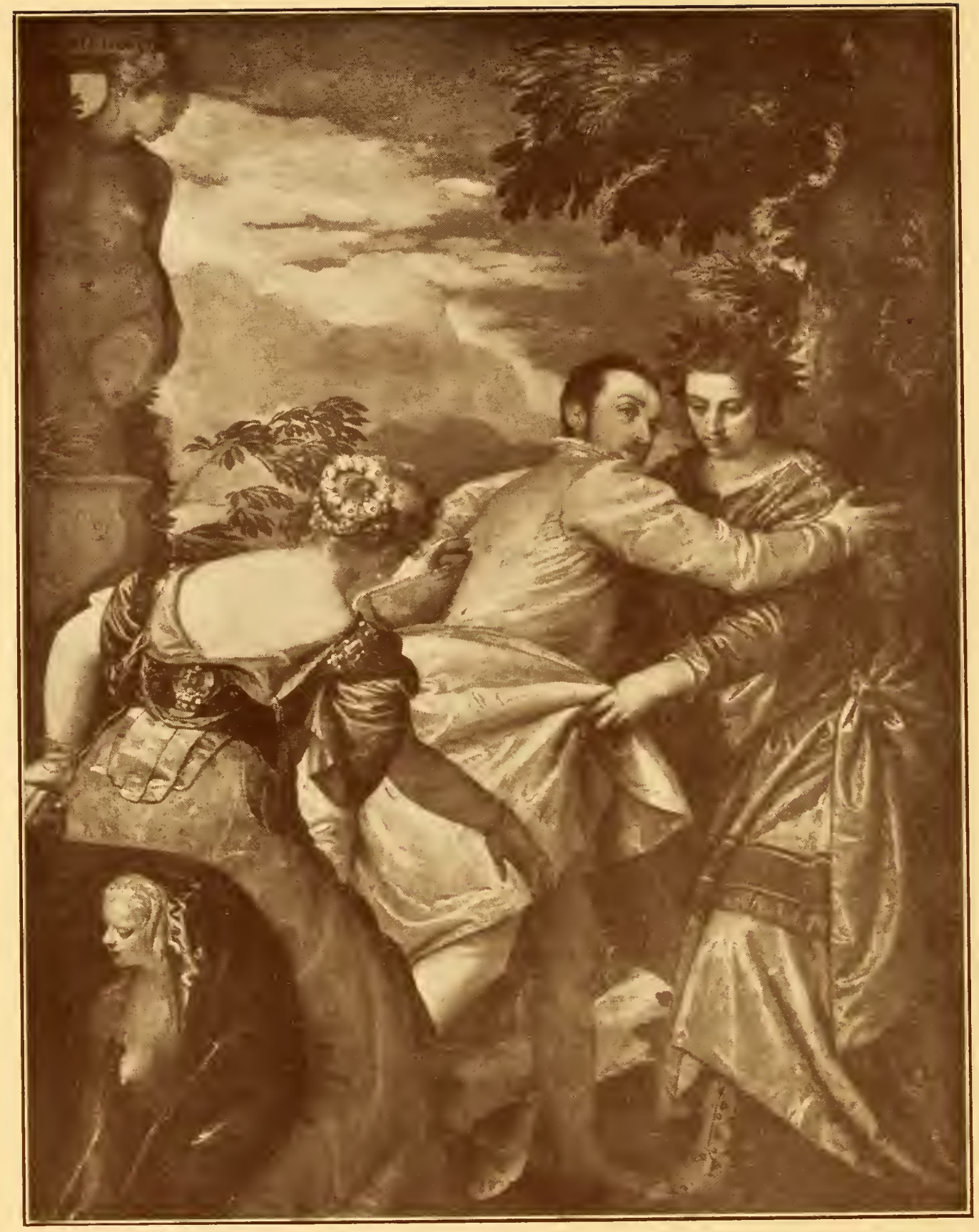




\section{PAUL VERONESE}

( I $528-\mathrm{I} 588$ )

ALLEGORIES OF WISDOM AND STRENGTH AND VIRTUE AND VICE

Canv'as, each 653/4 inches by 86 inches

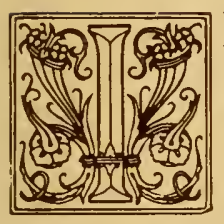

$\mathrm{N}$ the "Allegory of Wisdom and Strength" Wisdom is represented by a beautiful woman richly dressed. Her head is lifted to the sky, and surmounted by a sun, while a globe rolls at her feet. She seems entirely occupied with the contemplation of celestial things, disdaining honors and the vanities of the age. Hercules, who accompanies her, is the symbol of strength and firmity. $\mathrm{He}$ is clothed with the skin of a lion of the Nemean forest, is leaning on his cudgel and tranquilly regards worldly love at his feet. At the base of the column in the background are the words "Omnia Vanitas,"-_"all is vanity." On the cornice of the ornament is the Latin inscription "Honor et Virtus post mortem florent"- "honor and virtue flourish after death."

The three figures in the other picture are an allegory in which many think that Veronese himself is represented, but it is more likely to have represented the person for whom the picture was painted. Vice is the figure of a woman, with the hands of a harpy. She is holding a pack of cards and leans toward a man who is fleeing from her. He throws himself into the arms of Virtue, who approaches and holds him. Vice is seated, and underneath her drapery is perceived the bust of a sphinx and a poignard. Figuratively the sphinx is an impenetrable person, an individual capable of inventing difficult questions and problems, an enigma.

Engraved: "Galleries du Palais Royal," by J. Couchi. Paris, I786, Vol. II., plates III. and IV. of the Venetian School. "Recueil d'Estampes d'àpres les Plus Beaux Tableaux," Paris, I 729, Vol. II.

Described on p. 67, Vol. II., of the "Recueil d'Estampes." 


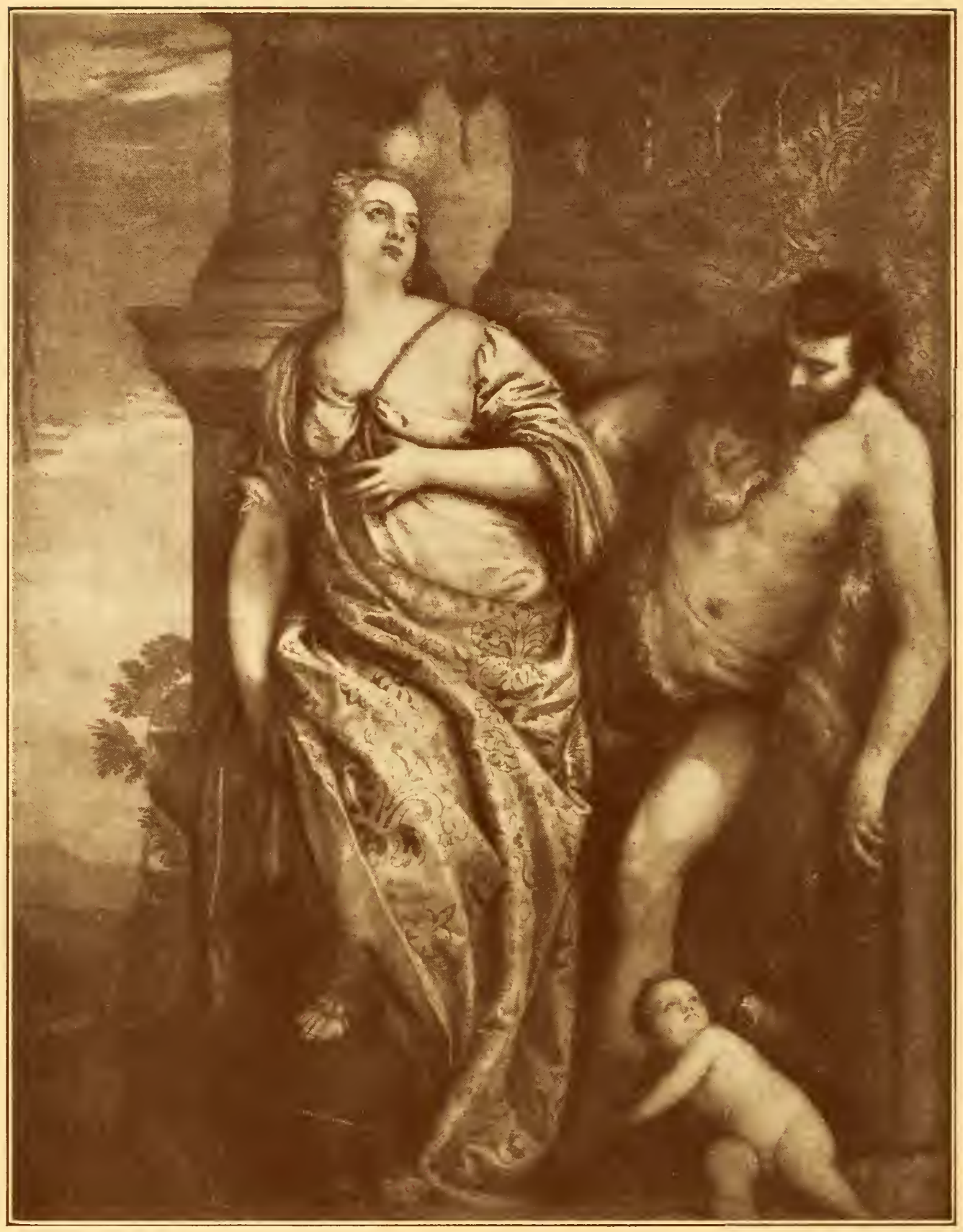


These two paintings at one time formed part of a collection of 47 paintings in the possession of Christina, Queen of Sweden. She inherited them from her father, the great Gustavus Adolphus, who had possessed himself of them on the reduction of Prague during the Thirty Years' IVar.

Christina removed her entire collection of paintings to Rome. At her death in I689, her paintings were bought by Cardinal Decio Azzolini. From his nephew they were bought by Don Livio Odeschalchi, Duke of Bracciano, and by his heirs sold to Philip the Regent, Duke of Orleans. His magnificent collection, which hung in the Galleries of the Palais Royal at Paris, was considered one of the finest collections of Europe. When he died in 1723 these paintings passed to his son, and so for four generations of the Dukes of Orleans, Philip Egalité being the last of that house to possess them.

In I 792, after the Revolution broke forth, Philip decided to sell them, being in need of finances for the furtherance of his political projects; and in this way the paintings found their way to England, into the Hope Collection, where they remained for the whole of the nineteenth century.

Thus, the collections to which belonged the two paintings by Veronese, are the following:

Collection of Gustavus Adolphus II. of Sweden.

" " Christina, Queen of Sweden.
" " Cardinal Decio Azzolini, Rome.
" " $\quad$ " Philip Odeschalchi, Duke of Bracciano, Rome.
" $\quad$ Phe Dukes of Orleans, in the Galleries of
" M. Walkners, Brussels.
" " M. Laborde de Mereville, Paris.
" "Thomas Hope, Esq., London.
"Thomas Henry Hope, Esq., Deepdene, Eng-
land.

Mentioned in Waagen's "Art Treasures of Great Britain," I 854, Vol. II., p. II 3 , and in Bryan's Dictionary, edition of I 893 , Vol. I., p. 2 I 3. 


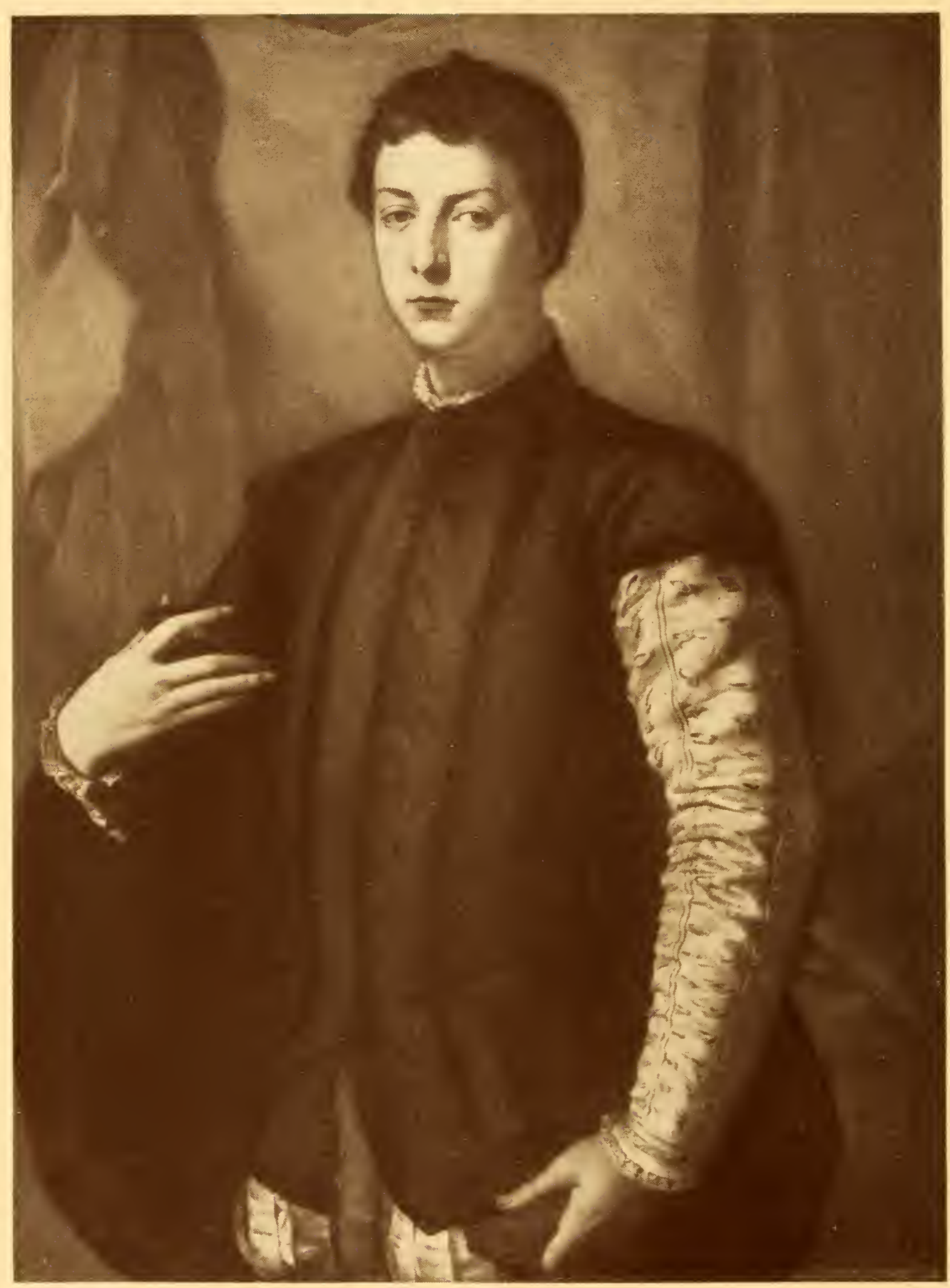


"BRONZINO" (ANGIOLO ALLORI)

\section{( I $502-1572)$ \\ PORTRAIT OF FRANCESCO MEDICI}

Panel, 34 inches by 46 inches.

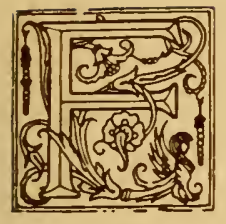

ULL half-length figure, standing, directed and looking to front, in black silk doublet with black braided bands over a white surcoat showing slashed sleeves, white lace cuffs, and white hose; his left arm hanging down by his side, and holding in his hand a small portfolio or purse; right hand raised, holding a medallion of which the subject is not seen; green background.

Painted about I 557-8.

Collection of Marchese Riccardi, Florence (?).

" " Lucian Buonaparte, Prince de Canino, I 8 I 6, No. 107.

" "Comte de Pourtales-Gorgier, Paris, I $\$ 65$, No. 22.

" " Baron Seillière, Paris.

" " " John Edward Taylor, London, I 9 I 2, No. I 4.

" " J. H. Dunn, London.

Illustrated, plate in the "Souvénirs de la Galérie, Pourtales," I 863 .

"No. I in the 1905 Portfolio of the Arundel Club, London.

" Frontispiece to the John Edward Taylor Catalogue.

Francesco de Medici, son of Cosmo I., Grand Duke of Tuscany; born I 54I; created Grand Duke by the Emperor Maximilian in I 576 ; died I 587 . A distinguished patron of the arts and sciences, and the first to discover the method of melting rock crystal; he was also the first to manufacture porcelain in imitation of the Chinese. He married first, in I 565 , Johanna, daughter of the Emperor Ferdinand I; she died in I 578 . He then married the beautiful Bianca Capella, daughter of a Venetian senator; she died in ${ }_{5} 87$. 


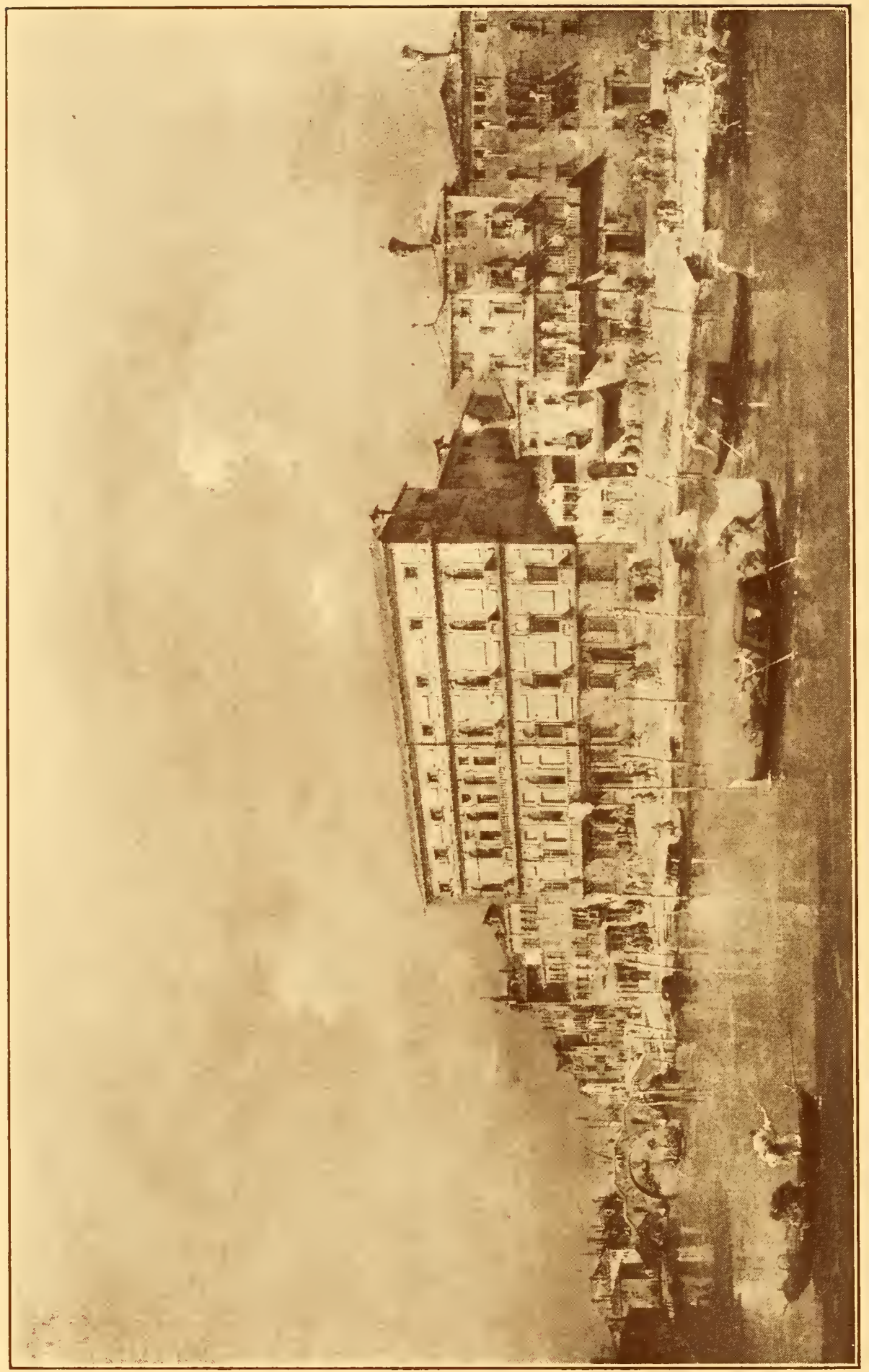




\section{FRANCESCO GUARDI}

\section{(I7I2-I793)}

VIEW OF GRAND CANAL, VENICE

AND

\section{CANAL SCENE, VENICE}

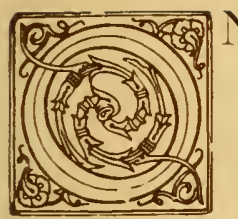

NE of these scenes is a sunny and brilliant view of a part of the Grand Canal. The other depicting a festival, with racing gondolas, is taken from a lower part of the Grand Canal. The end of the Rialto is seen in the middle distance. The exquisite detail of both pictures, but especially that of the brighter one, is thoroughly characteristic of Guardi.

These pictures originally belonged to Mr. J. Strange, British Minister at Venice, I774-86. He left them to his nephew, the Rev. C. Nares, D.D., and at Dr. Nares' death in I 84 I they passed to his daughter, Lady Henry S. Churchill, from whom they came into the possession of her nephew, the Rev. G. Cecil White.

Francesco Guardi was a pupil of Canaletto, whom he almost outranked in reputation. Many of his paintings are now accredited to Canaletto, notably some of those in the museum at Naples. His execution is generally less precise than that of his master and less exact in the architectural details in which both excelled; but his paintings are brilliant and rich, and his coloring forceful. Like Canaletto, he restricted himself to views of his native city, which furnished him with all the needful variety of picturesque and beautiful effects of light and water with which he has embellished his works. 


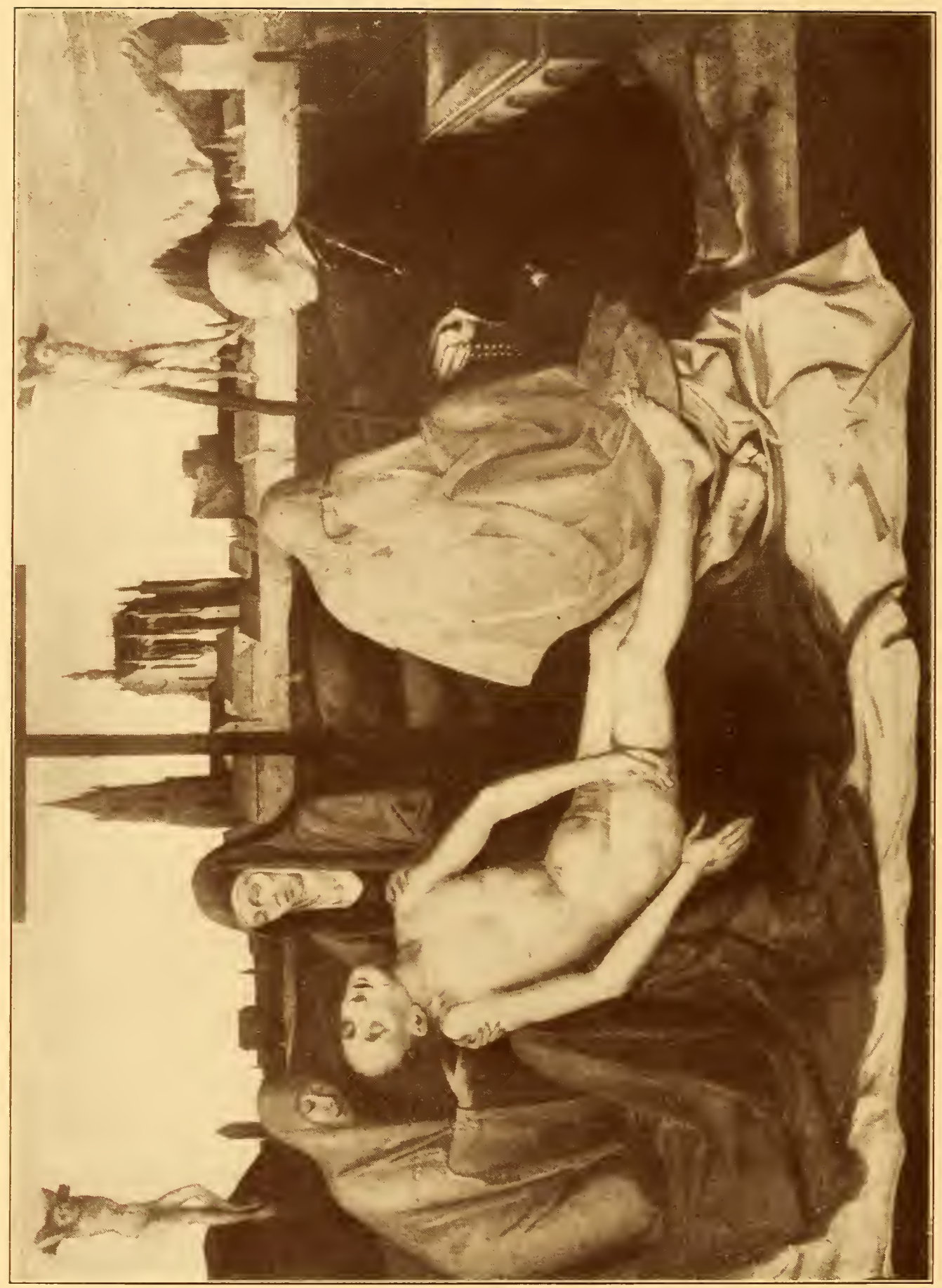




\section{ANT@NELLO DA MESSINA}

$$
\text { ( } 1450 ?-1493 ? \text { ) }
$$

\section{THE DEPOSITION FROM THE CROSS}

HIS beautiful primitive has excited much interest among critics by reason of its exhibiting both Flemish and Italian qualities at a period in the development of art when these influences were strongly opposed. It first became known to the modern art world in 1902, when it was exhibited at Bruges, and catalogued as the work of Antonello da Messina, who lived in the latter half of the fifteenth century, and is supposed to have introduced painting in oil into Italy. It is believed by some critics to be the historic picture described by Boschini in La Ricche Minore della Pittura. Mr. Roger E. Fry has made it the subject of a critical essay in the Bulletin of the Metropolitan Museum of Art, written in December, 1907, while the painting was in that museum. Discussing the picture in 1902, Mr. Fry was impressed by this mixture of Flemish and Italian influences, and "came tentatively to the conclusion that it was by an Italian artist under the influence of Justus, of Ghent, who was settled in Urbino. Since the picture came to America," he adds, "a more prolonged and minute examination of it has led him to the conclusion that, after all, the original attribution to Antonello da Messina is correct."

Another critic comments on the Flemish and Italian influences which "modulate in subtle succession over the canvas," and he supports Mr. Fry's attribution to Antonello. "The canvas," he adds, "breathes the spirit of faith in which it was conceived and executed; it also is painfully veracious in the presentation of lacerated bodies and souls." 


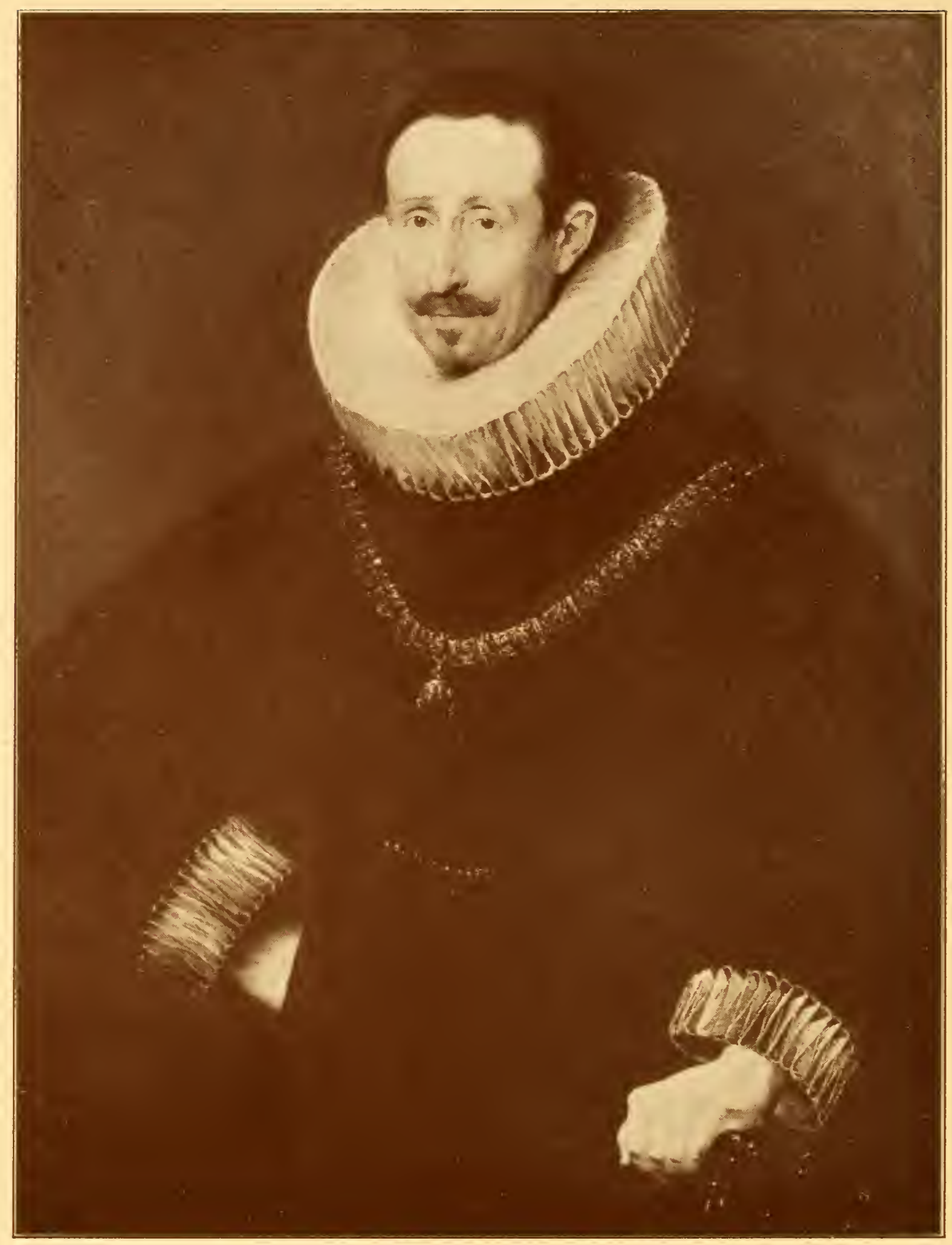




\section{PETER PAUL RUBENS}

\section{( I $577-1640)$ \\ PORTRAIT OF AMBROSE DE SPINOLA}

Canvas, 303/8 inches by $395 / 8$ inches

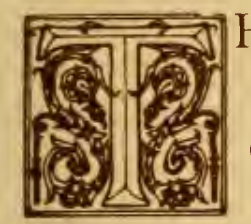

HREE-QUARTER length, half-turned to the spectator; in quasi-military costume, and carrying the chain of the Spanish order of the Golden Fleece.

From the Collection of Count de Renesse, Castle Mayen, on the Rhine.

Dr. Bode, in a letter concerning this portrait, written March 29, 19II, from the Koenigliche Museen, Berlin, says:

"The portrait by P. P. Rubens you showed me does not represent the Emperor Rodolphe II, as many engravings and medals of the Emperor prove. Besides, he died some years before Rubens painted the picture, as costume and treatment appoint it to the year 1614 or 1615. The order of the Golden Fleece, however, proves that the man represented had a high position in his time, and that is why I hope to find out one day who it was. The picture is entirely painted by Rubens, carefully executed by him and yet shows much spirit, especially in the treatment of the hands. It is very lifelike, for Rubens was unusually true to nature, and in conception simple and distinguished. As a lifesize figure, nearly to the knees, it is a very rare object on the market. The picture is in a very good state."

The portrait has since been identified as that of the Marquis Ambrose de Spinola, born in Genoa, I 569, died near Casale, Piedmont, 1630. He was commander-in-chief of the Spanish army in the Netherlands, and was the hero of the siege of Breda, immortalized by Velasquez in his celebrated painting representing the surrender of the keys of that citadel, and known as Las Lanzas. In that painting Velasquez drew Spinola's portrait from memory, and it bears a striking resemblance to the present likeness. 


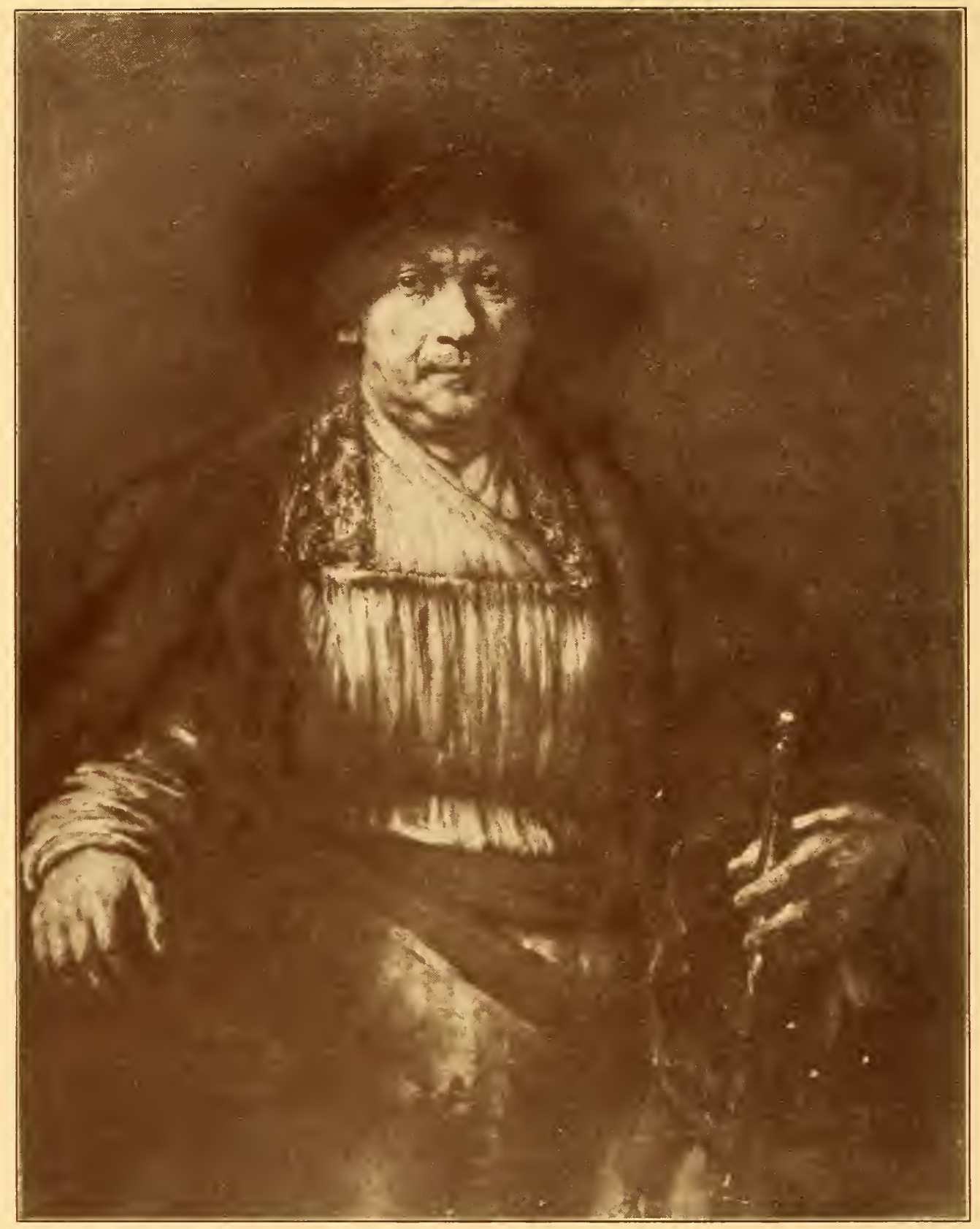




\section{REMBRANDT VAN RYN

$$
\text { ( I607-I669) }
$$

\section{PORTRAIT OF HIMSELF}

\section{Canvas, $4 I^{1} / 2$ inches by $5 I^{1} / 2$ inches}

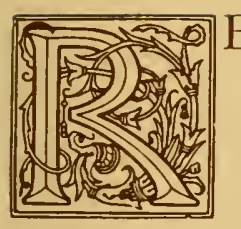

EMBRANDT, seated with a stick in his left hand, about fifty years old, seated facing and looking at the spectator. In a full yellow gaberdine, with a red sash, a brown cloak with white neck-cloth, and gold embroidered shoulder straps. On his head he wears a dark cap under which a brown skull cap is visible. He has a short mustache. In his left hand he holds a stock, with a silver knob, dark background."-Quoted from Dr. Bode's "Rembrandt," Vol. VI., p. 88, No. 428.

Dr. Bode calls this the most dignified of all Rembrandt's portraits. "The attitude and expression," he says, "are so imposing, so full of distinction and calm, that we might rather suppose the work to represent some commercial magnate of Amsterdam, such as the President of the East India Company, than one of the poorest artists of the city."

"In this portrait," says Mr. C. J. Holmes, the well-known art critic, "Rembrandt has withdrawn himself into this world of his own creation, and sits there in state, clad in rich, easy robes, like an aged prince on a throne, looking out on humanity with the piercing eyes of profound knowledge and infinite experience. The troubles and disasters of his terrestrial life, bereavement, the neglect of his contemporaries, bankruptcy, poverty, have no place here-he is a king in his own kingdom, and these calamities of his material existence leave him unmoved and unaltered, except in so far as their impact in the past has left its mark upon the rugged face."

Exhibited in British Institute, I 8 I 5 ; British Gallery, I 824; Burlington House, I 889.

Signed on the knob of the chair, "Rembrandt f. I 658."

Collection: Earl of Ilchester, Melbury Park, England. 


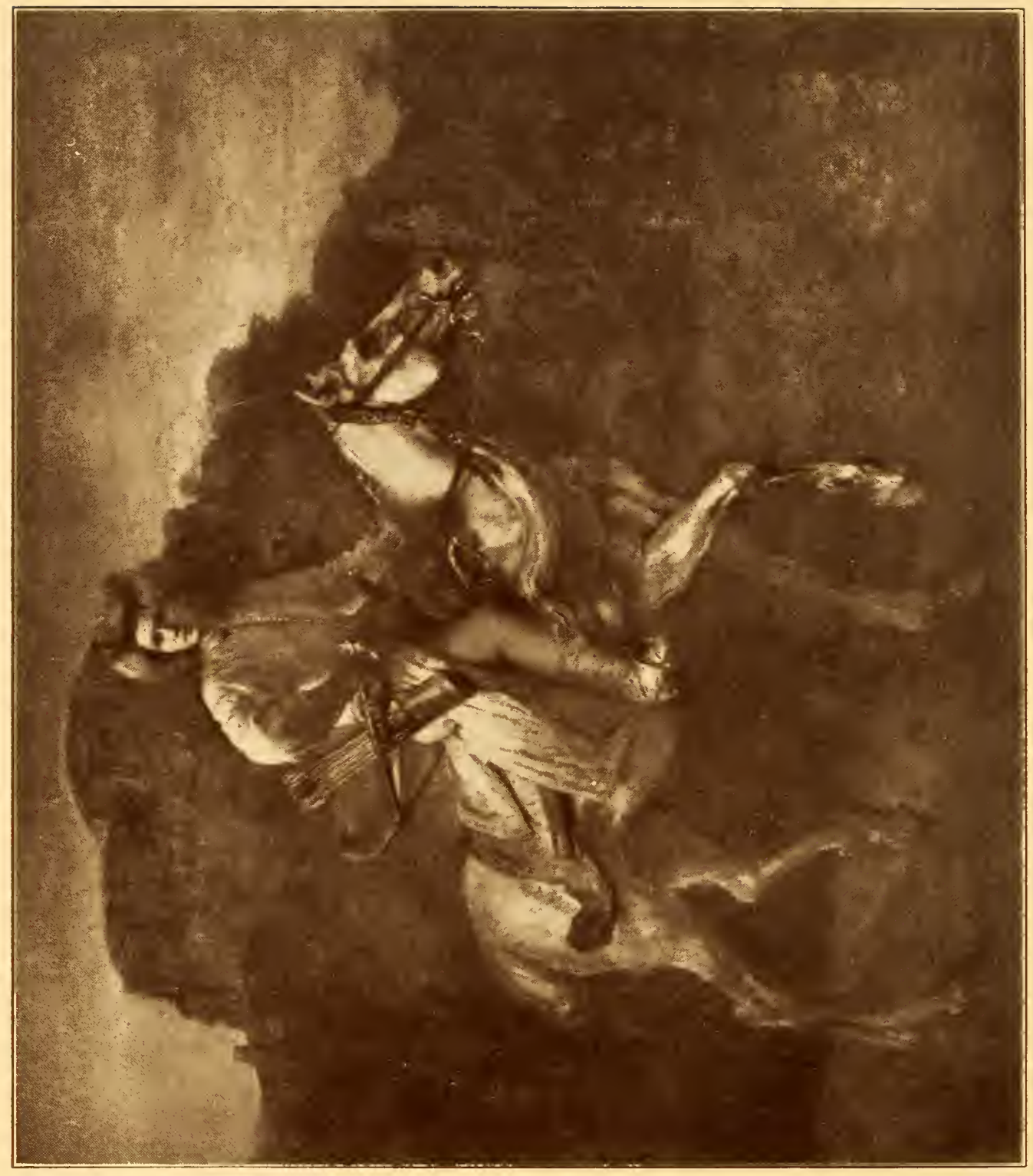




$$
\text { ( I607-I669) }
$$

\section{A YOUNG POLISH CAVALIER}

YOUNG patrician horseman advances towards the right in a hilly landscape, on a light gray horse which bears a panther-skin for a saddle-cloth, and turns his handsome beardless face to the spectator. He wears a long light yellow tunic, closely fastened at the top with a number of blue buttons, tight red breeches, yellow boots, and a red cap with a wide border of fur. In his right hand, which is pressed against his side, he holds a mace; at his right side hangs an Oriental leather quiver and a bow; on either side, a long sword. The reins are of red Russian leather; a fox's brush dangles from the horse's neck. In the background is a large fortress on a high mountain; to the left at the foot of the mountain, a waterfall is distinguishable in the penumbra; to the right a little lake with buildings on the shores and a watch fire. The rays of the evening sun fall on the horseman from the left."-Quoted from Dr. Bode.

Painted about I 655 .

Exhibited at Amsterdam in I $\$ 9 S$.

From Count Tarnowski's Collection, Dzikow, Galicia.

Does he ride to a bridal, a triumph, a dance or a fray,

That he goes so alert, yet so careless, so stern and so gay?

Loose seat in the saddle, short stirrup, one hand on the mane

Of the light stepping pony he guides with so easy a rein.

What grace in his armor barbaric! sword, battleaxe, bow, Full sheaf of long arrows, the leopard-skin flaunting below. Heart-conqueror, surely-his own is not given, awhile,

Till she comes who shall win for herself that inscrutable smile.

What luck had his riding, I wonder, romantic and bold?

For he rides into darkness; the story shall never be told.

Did he charge at Vienna, and fall in a splendid campaign?

Did he fly from the Cossack, and perish, ingloriously slain?

Ah, chivalrous Poland, forgotten, dishonored, a slave

To thyself and the stranger, fair, hapless, beloved of the brave!

-F. Warre Cornish on "The Polish Rider" in the Spectator. 


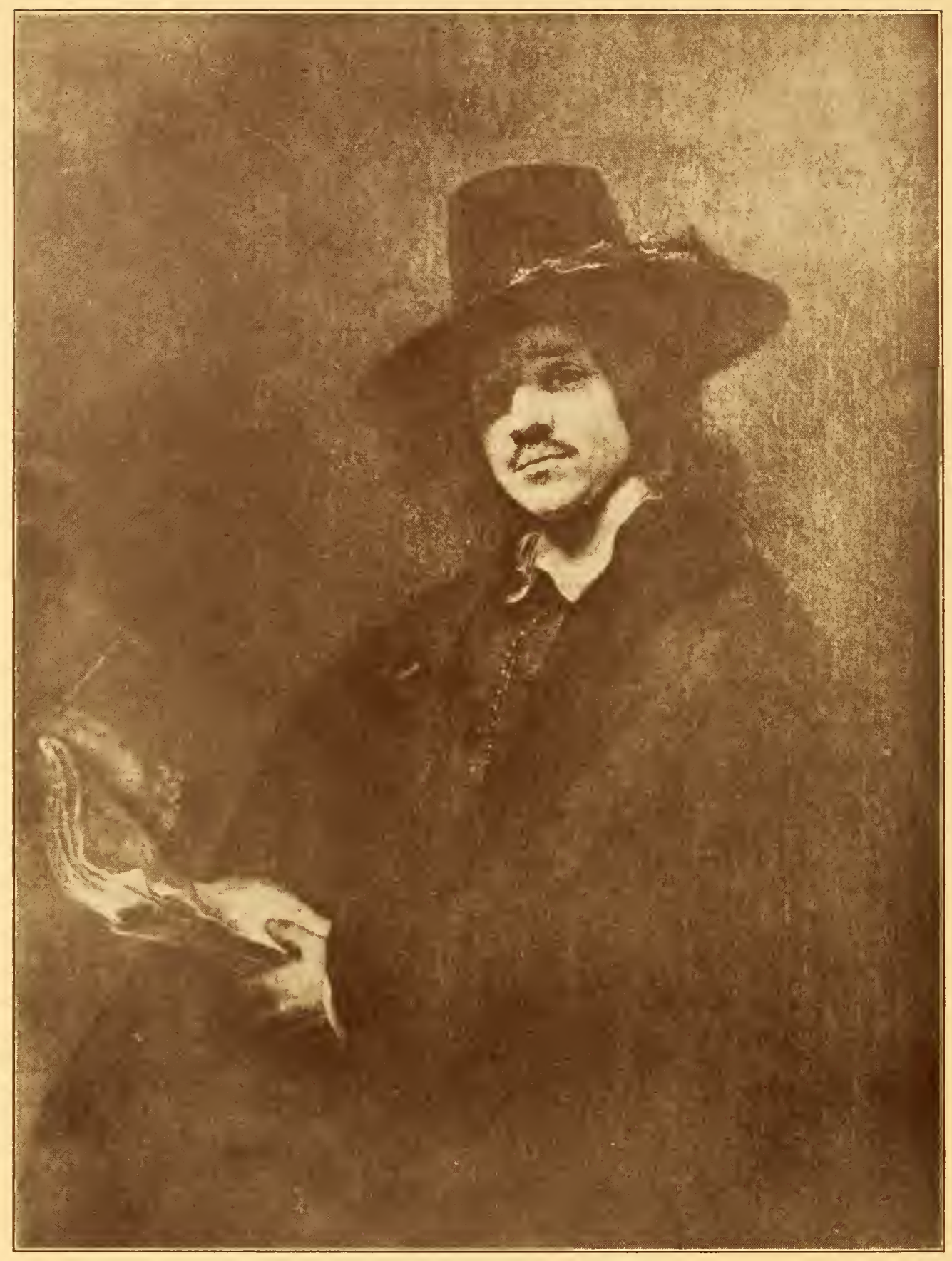




\section{REMBRANDT VAN RYN}

$$
\text { ( 1607-1669) }
$$

\section{A YOUNG PAINTER}

Canvas, 35\% inches by $443 / 4$ inches, strip $5^{\mathrm{T}} / 2$ inches joined

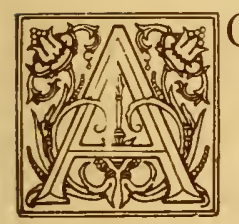

GED about five and twenty, turned to the right, seated at a table with a red cover, and looking at the spectator; with his left hand he holds some loose sheets of paper before him; his right hand, in which he grasps a pencil, rests on the edge of the table. On his long dark brown hair he wears a broad-brimmed hat, entwined with a trail of blossom, which throws a shadow over the upper part of his face. Closely clipped moustache. He is dressed in a full black coat over a golden green doublet, with a plain white collar and cuffs to match." -Quoted from Dr. Bode's "Rembrandt," Vol. V, p. 365.

Signed at the upper right, below the strip of canvas that has been added, "Rembrandt f. I 647 ."

Various hypotheses as to the identity of the sitter, sometimes erroneously called Leonhard Bramer, have no secure basis.

Reference to this picture is also made in Smith's catalogue Raisonné, Part VII., No. 388, and Dutuit (Supplement), p. 43, No. 3 I 4, Wurzbach, No. I64, "Singularly noble in expression and action and admirably painted in a light golden tone." Michel, pp. 382, 555 ; also Waagen's "Art Treasures," Vol. II., p. 280 .

Exhibited at the Amsterdam, I 898, No. 70.

" " " "New York Hudson-Fulton Celebration, I 909. " " "Boston Museum of Fine Arts, I9 Io.

Collection: Aved, Paris, I 766. ،

Earl of Carlisle, Castle Howard, Yorkshire. 


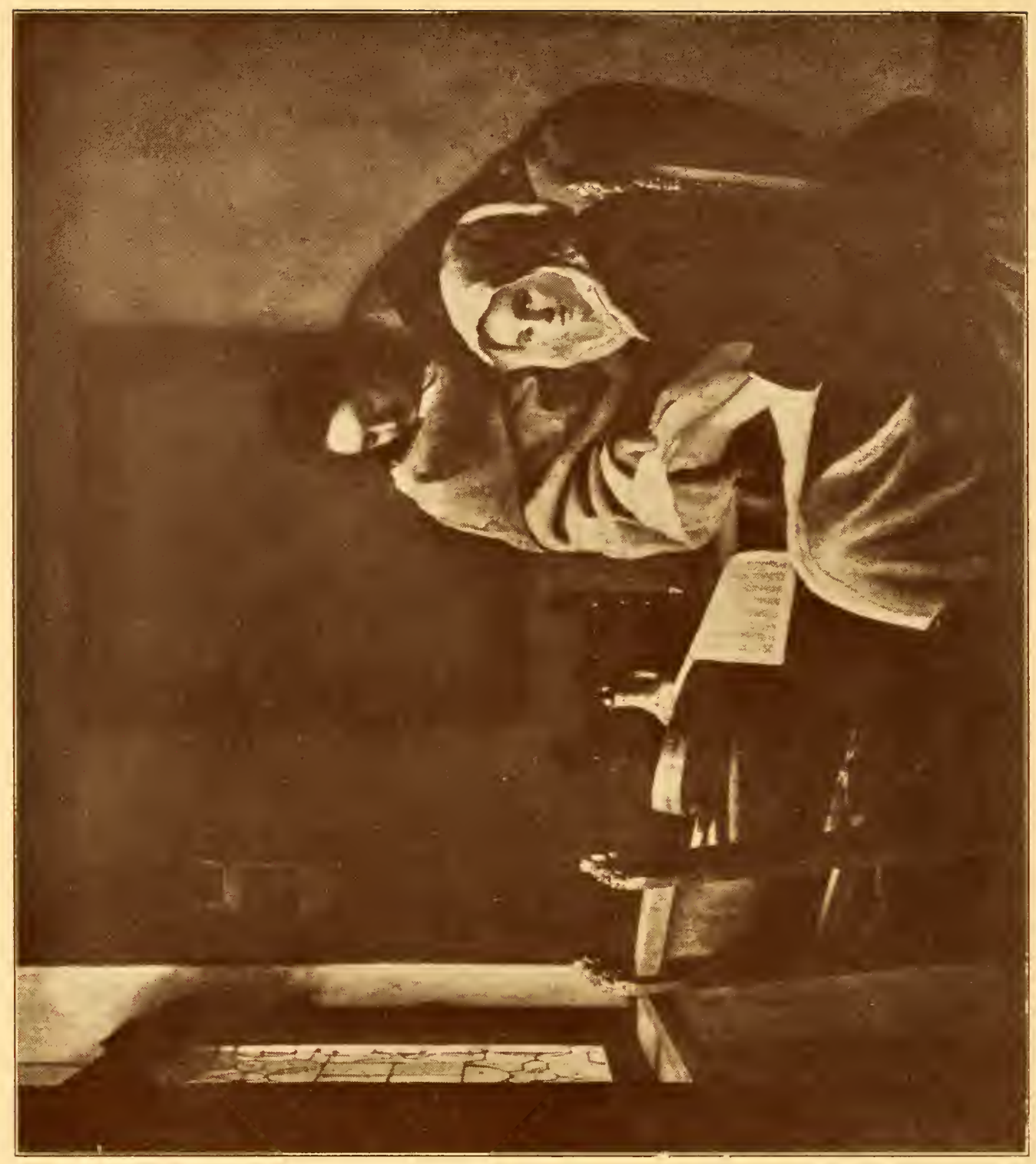




\title{
JAN VERMEER OF DELFT
}

\author{
$(1632-1675)$ \\ THE MIUSIC LESSON
}

Canvas, $173 / 4$ inches by $153 / 8$ inches

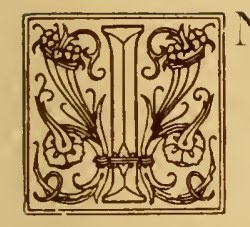

the left-hand corner of a room sits a comely girl in a red jacket, white cap and blue skirt, holding a sheet of paper, apparently music. She is in profile to the right, but turns her head to the spectator. A man in a bluish-gray cloak, without a hat, steps toward her, lays his left hand on a chair and grasps the sheet of paper with his right. On the table are a mandolin, a musicbook, a blue China jug and a glass of wine. In front of the table is a chair with a dark blue cushion; behind the table is another chair. To the left is a window which is much foreshortened. Near it a bird-cage has been painted in by a later hand. On the back wall hangs a picture, almost square in shape, representing the Cupid standing, which appears also in the National Gallery picture ( 1906 catalogue, No. 1383). This picture of a Cupid became visible when the work was cleaned. Its place was formerly occupied by a violin and bow, noticed in the catalogue of the Smeeth van Alphen sale of I 8 IO. There are many blue tones; even the piece of music is printed in blue, and there are blue shadings on the red window frame."-Quoted from De Groot.

Mentioned in H. Havard's "Ver Meer of Delft."

" "Chas. H. Caffin's "Story of Dutch Painting."

Reproduced in Hofstede de Groot's "Jan Vermeer of Delft."

Illustrated in Burlington Magazine, XVI., 244.

Exhibited at the Burlington Fine Arts Club, I 900.

Collection of P. de Smeth Van Alphen, Amsterdam, i 8 Io.

" " $\mathrm{H}$. Croese, Amsterdam, i 8 I I.

" " C. S. Roos, Amsterdam, i 820.

" " Lewis Fry, Clifton, Bristol. 


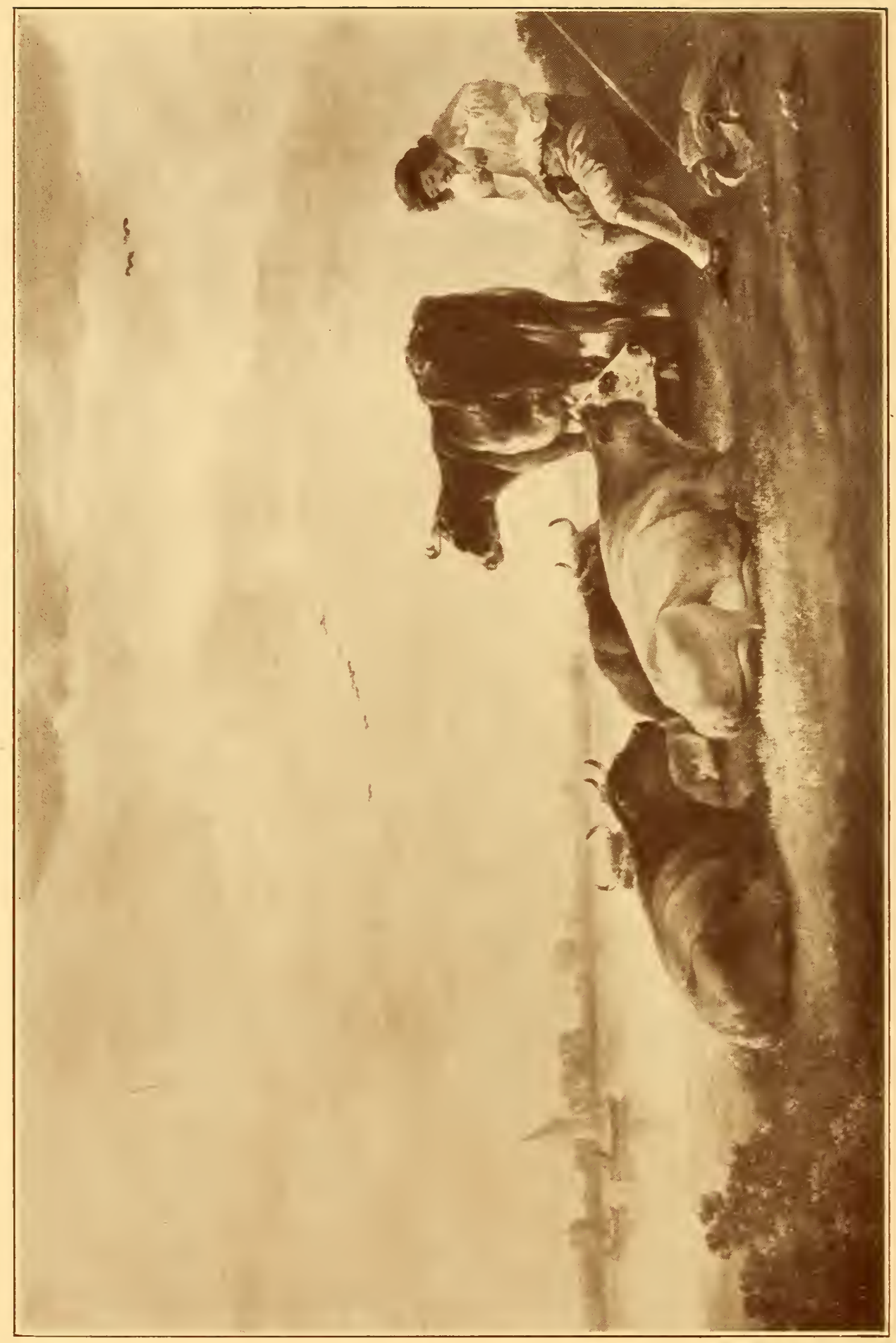




\section{AELBERT CUYP \\ HERDSMAN AND COWS ON A RIVER BANK \\ Panel, 201/4 inches by $195 / 8$ inches}

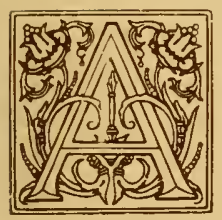

MEADOW, in which are a herd of five cows; four of them are lying down on the bank of a river. The herdsman, stripped to his shirt, is seated at the side looking for a flea. A river extends along the middle distance, on which are two small sailing boats; and the view is bounded by a line of low coast.

Signed at the lower right "A. Cuyp."

From the Collection of Philip H. Hope, Esq., Deepdene, England.

RIVER SCENE WITH A BARGE FULL OF PASSENGERS Panel, 291/4 inches by $23 \mathrm{~T} / 4$ inches

$N$ the river to the right, and close to the spectator, ( is a large sailing ship, with numerous passengers. It carries a Dutch flag and a red flag with a white 32. 20. bird. Other smaller vessels are in the distance. At the left is a landing-place with ducks.

Signed on the rudder "A. Cuyp."

Mentioned in Waagen's "Treasures of Art in Great Britain," Vol. II., p. 279.

Mentioned in C. Hofstede de Groot's Catalogue of Dutch Painters, I909, Vol. II., p. I89, No. 633.

Exhibited at the Royal Academy, I 890, No. 80.

Previously owned by the Earl of Carlisle, Castle Howard, Yorkshire. 


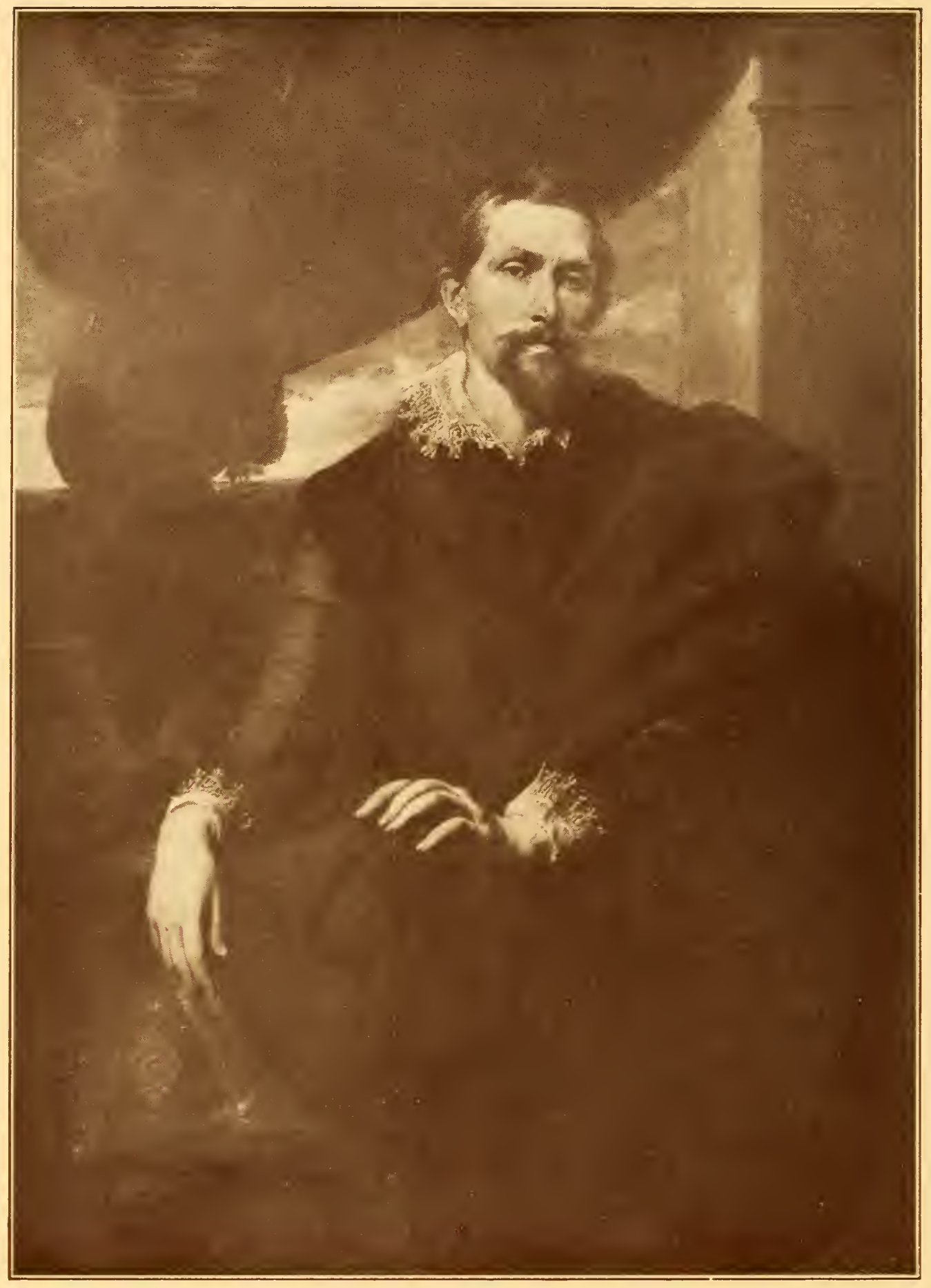




\section{SIR ANTHONY VAN DYCK}

\section{( I 599-I64I) \\ FRANZ SNYDERS \\ Canvas, 50 inches by 37 inches}

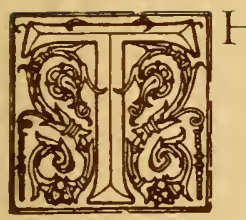

HE portrait of Franz Synders the painter; threequarter view, the head leaning a little on one side, in a lace ruff and black silk dress, his hands resting on a chair. The background a landscape. To the knees. $4 \mathrm{ft} .2 \mathrm{in}$. high, $3 \mathrm{ft}$. I in. wide. This picture was painted in the Netherlands, shortly before Van Dyck came to England. The noble conception, with which a slight trace of melancholy is blended, the admirable drawing (for instance, the foreshortened ear), the masterly modelling, the gradation in a warm, clear, yellowish tone, nearly akin to that of Rubens, and the simplicity of the forms, render this not only one of the very finest portraits by Van Dyck, but entitle it to rank witt. the most celebrated portraits by Raphael, Titian or Holbein." -Quoted from Waagen's "Art Treasures of Great Britain," III., 3 I 9.

Franz Snyders, born in Antwerp, I 579, painted animals and hunting scenes with surprising fire and spirit. The talents of Snyders excited the admiration of Rubens, who frequently intrusted him to paint the animals, fruit, etc., in his pictures. For the Archduke Albert he painted some of his finest works, particularly a stag hunt, which was sent by the Archduke to Philip III. of Spain, who commissioned Snyders to paint several large hunting pictures and combats of wild beasts, which are still in the old palace of Buen-Ritiro. His pictures are to be found in all the chief public galleries of Europe.

He was Van Dyck's intimate friend, and was painted by him a number of times, notably in the Cassel Gallery with his wife, and in the family group with his wife and children at the Hermitage, Petrograd.

The present portrait was formerly in the collections of the Duc d'Orleans and of the Earl of Carlisle. It was etched by Van Dyck himself. 


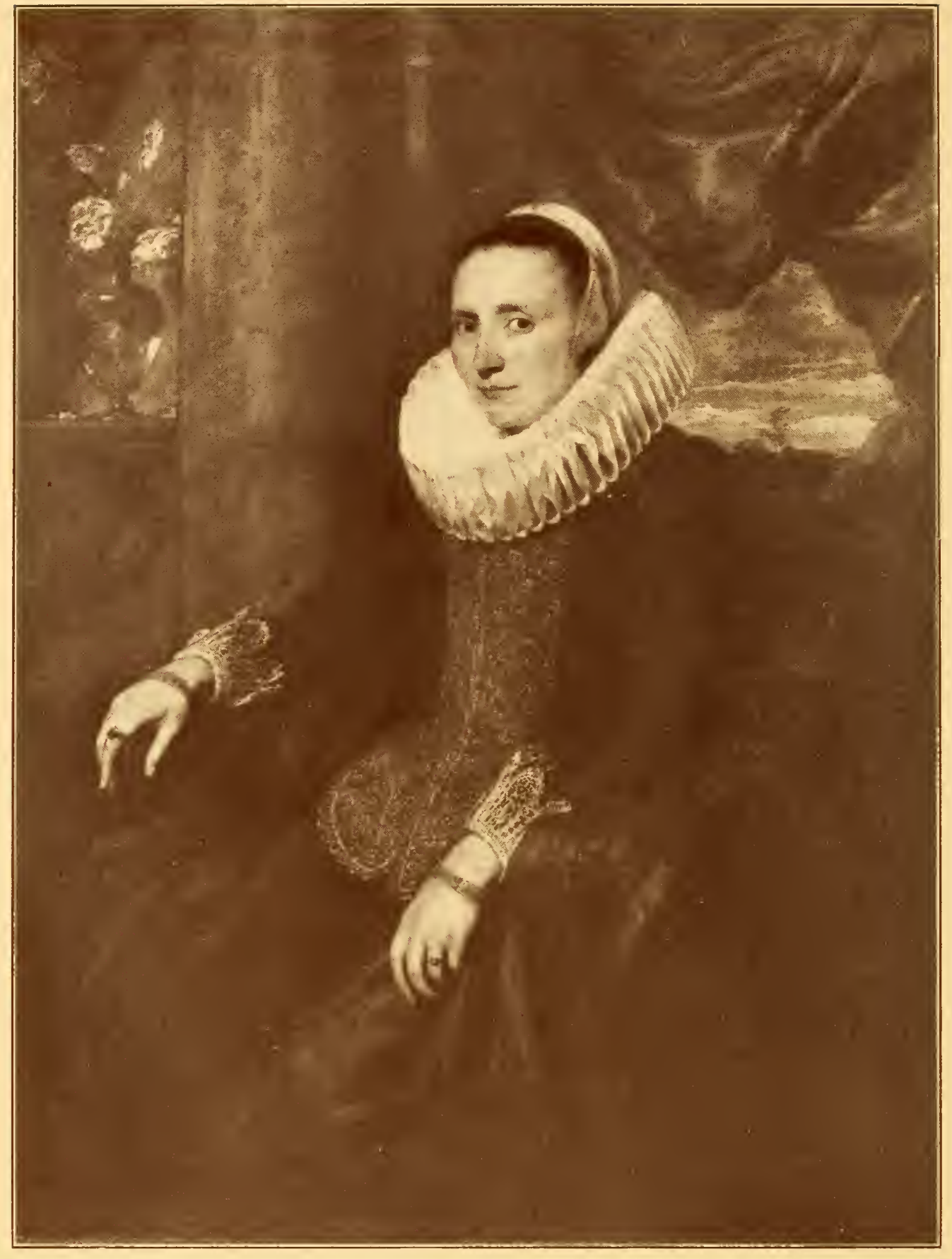




\section{SIR ANTHONY VAN DYCK}

\section{( I 599-164I)}

MARGARETHA DE VOS, WIFE OF FRANZ SNYDERS

Canvas, 50 inches by 37 inches

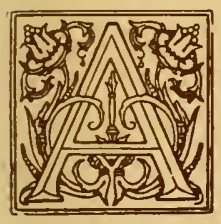

LADY of fair complexion, represented in a threequarter view, with the head inclining downwards; her dark hair is nearly concealed by a close white cap, and a broad, full ruff adorns the neck.

She was the sister of Cornelius de Vos (1585-165I) the painter of historical pictures and portraits, and friend of Van Dyck. De Vos was also painted by Van Dyck.

The portrait is mentioned in Waagen's "Art Treasures of Great Britain," III., p. 2 I3:-“"The wife of Franz Snyders, in a white cap and a broad ruff. The handsome face is painted in his earlier style, with great simplicity of feeling, in a very clear tone, resembling that of Rubens."

Also mentioned in Smith's Catalogue Raisonné, III., 96.

" " " "Lionel Custs' "Anthony Van Dyck."

" " " " Burlington Mag., XVI., 30I, by William Walton.

It is probable that this portrait was painted in $162 \mathrm{I}$, at the same time as that of Franz Snyders. They both formed part of the collection of the Duc d'Orleans, but when this was dispersed during the troublous times which followed the French Revolution, the portraits of Snyder and his wife were separated, the former going into the collection of the Earl of Carlisle, and the present one into that of the Earl of Warwick-whose wife is the Henrietta Vernon of the Romney portrait in Mr. Frick's Collection. The portraits of Franz Snyders and his wife are now happily reunited after a century of separation, although at the Manchester Exhibition in 1857 they came together for a brief period. 


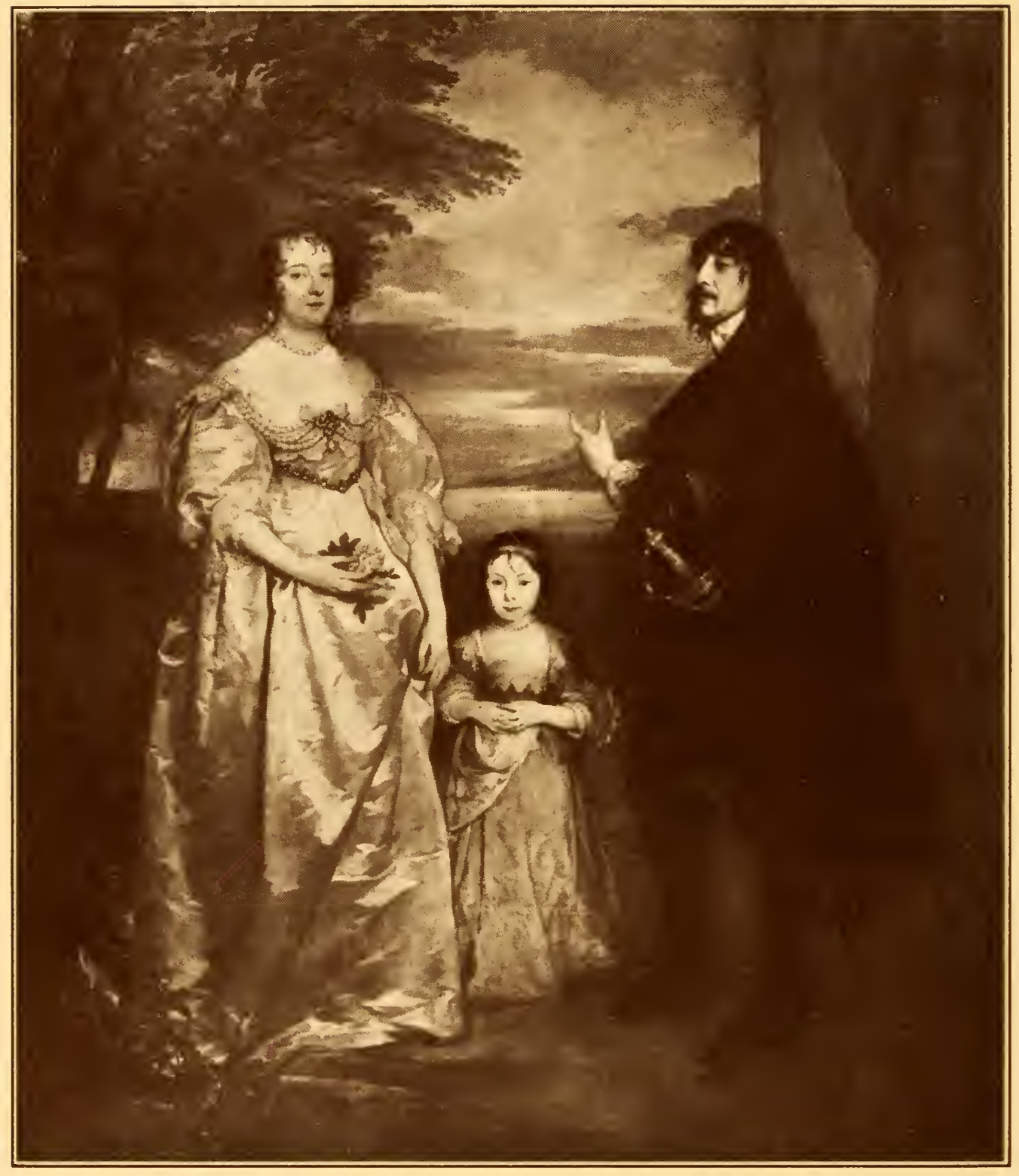




\section{SIR ANTHONY VAN DYCK}

( I 599-I64I)

JAMES STANLEY, SEVENTH EARL OF DERBY, CHARLOTTE, HIS WIFE, AND HIS DAUGHTER

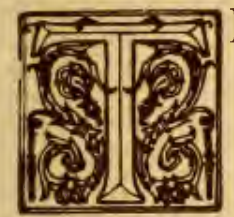

HE Earl is represented standing on the left, habited in a full suit of black silk, and a mantle of the same. His left hand is raised, and the forefinger points upward. His lady is on the opposite side; her fair countenance is seen in a three-quarter view, with dark hair, tastefully arranged in curls. Her dress is composed of white satin; a pearl necklace, and a triple row of the same jewels adorn the bosom; the waist is encompassed with a girdle of costly gems; the right hand holds a bunch of roses, and the left is extended to raise the skirt of her robe. In the centre, between them, stands their daughter, who is apparently about five years of age, and is seen in a front view, wearing a red silk frock, the bosom of which is surrounded with lace; her hands are united in front. A landscape with a wide expanse of water compose the background. A truly excellent production."-Quoted from Smith.

Vaagen in his "Art Treasures of Great Britain" (Vol. II., p. 455) makes mention of this portrait:

"James Stanley, seventh Earl of Derby, and his wife, Charlotte Tremouille, daughter of Claude de la Tremouille, Duke of Thouars, with a little girl, daughter Catherine, afterwards married to Wm. Pierrepont, Marquis of Dorchester. Both these distinguished persons, who were devoted to the royal cause, for which he suffered on the scaffold, have been admirably preserved to posterity in this picture. This nobly and elegantly conceived picture unites that golden tone in the female portrait and those powerful brownish colors in that of the man, which were peculiar to the painter in the earlier part of his residence in England. Painted about I632-3."

This is a historic painting and comes from the collection of the Earl of Clarendon. 


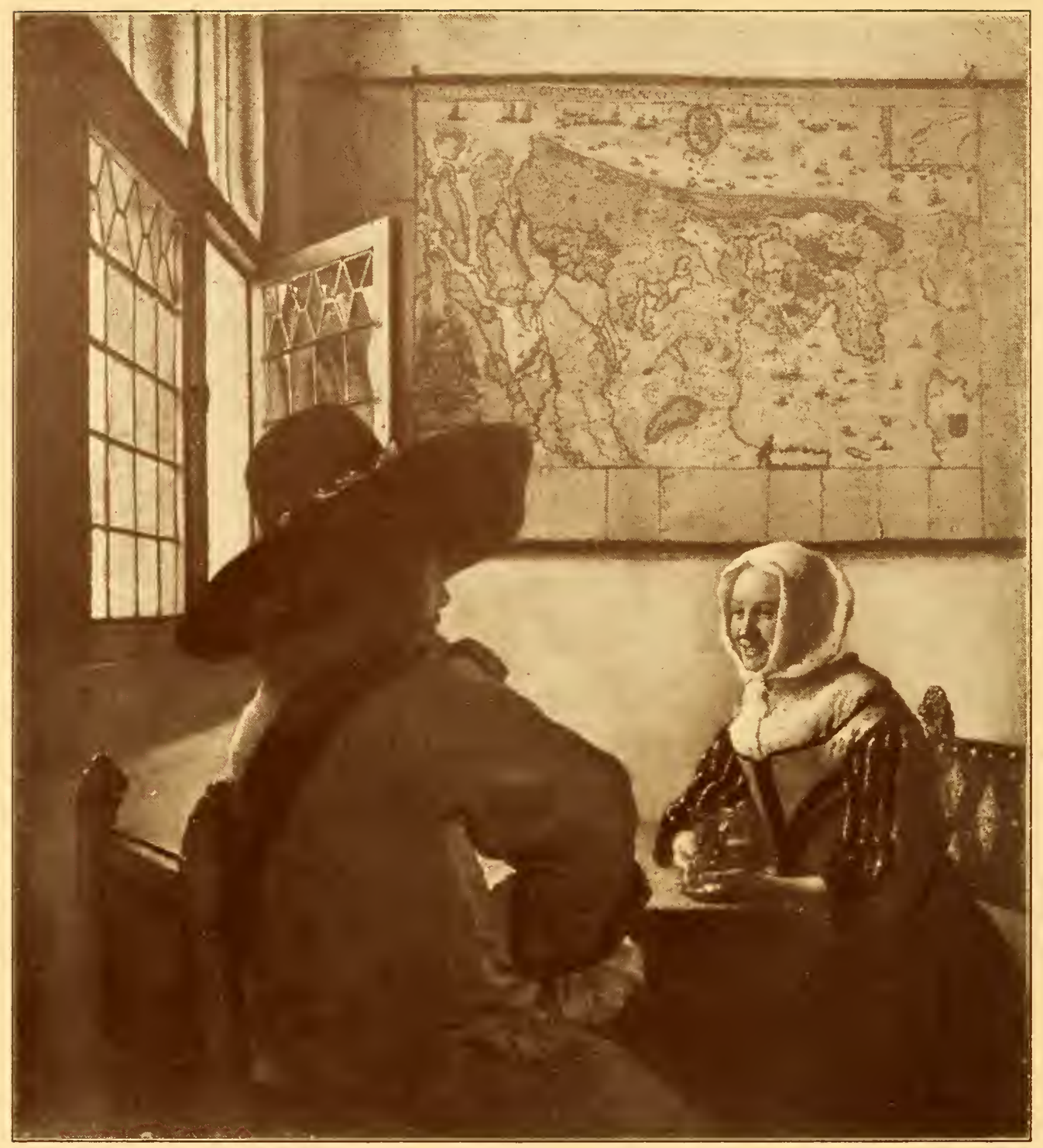




\section{JAN VERMEER OF DELFT}

\section{( I632-I675)}

\section{THE SOLDIER AND THE LAUGHING GIRL}

Canvas, 18 inches by $197 / 8$ inches

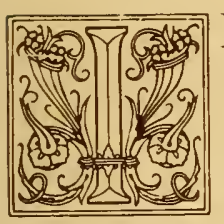

$\mathrm{N}$ the left-hand corner of a room a soldier and a girl sit conversing at a table with a blue cover. The soldier is in shadow in the left foreground and is seen in profile; he wears a large black slouch hat with a red ribbon and a red coat with a bandolier, and rests his right hand on his hip. The girl sits more to the right and farther back; she wears a white cap, a black and yellow bodice and a blue skirt. In her right hand she holds a wine glass; her left hand rests on the table. To the left is a window with one casement open. On the wall hangs a map of Holland and West Friesland.

Referred to by Bürger in an article on "Van der Meer de Delft," published in the Gazette des Beaux Arts, I 866.

Engraved by Jules Jacquemart.

Reproduced in de Groot's portfolio, plate 27.

" "Grafton Gallery Catalogue, i 909-I9 Iо.

Mentioned in Havard's list, No. 7.

$$
\begin{aligned}
& \text { " " "Bryan's Dictionary, Vol. V., p. } 289 . \\
& \text { "C. Hofstede de Groot. } \\
& \text { "Van Zype's book on this artist. } \\
& \text { " the Gazette de Beaux Arts, i 866, Vol. XXI. } \\
& \text { "The Outlook, March, ig Io, p. } 485 . \\
& \text { " Burlington Magazine, December, I } 9 \text { I o. }
\end{aligned}
$$

Exhibited at Champs Elysees, Paris, No. ro7.

"Grafton Gallery, I 909-ro.

"the Burlington Fine Arts Club, I900, No. I 8.

" "Old Master Exhibition, Knoedler \& Co.

Sale, Amsterdam, May i6, i696, No. i I ( 44 florins).

Collection of Leopold Double, I 866.

"Mrs. Samuel S. Joseph, London. 


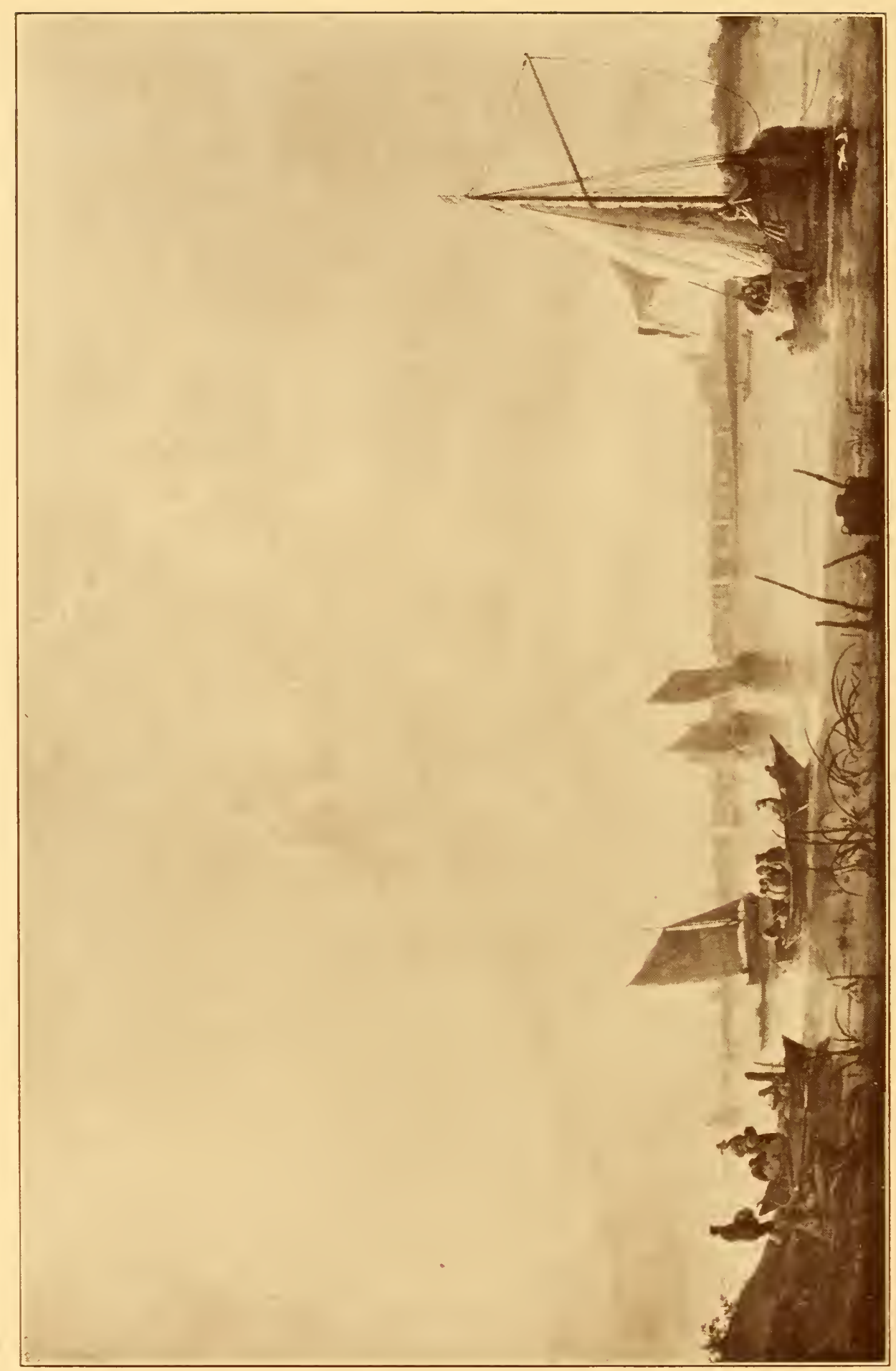




\section{AELBERT CUYP}

\section{( $1606-169$ I ) \\ SUNRISE ON THE DORT \\ Canzas, $6+$ inches by $+13 / 8$ inches}

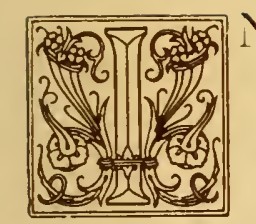

the immediate foreground on the left two men in a boat, one of whom is shooting at some ducks seen in the extreme right of the picture. On the bank beyond three men are seen busily loading two boats with sacks. In the foreground to left centre are two fishing boats. On the right a man in a rowboat fishing; close by, a sailboat. In the middle distance and beyond, other sailboats. The town stretches along the opposite bank of the river.

Signed on the boat at the lower left, "A. Cuyp."

Aelbert Cuyp was born at Dordrecht, in 1606 , the year that also gave Rembrandt to Holland. Little is known of his life. Like Rembrandt, he lived surrounded by political and religious strife; yet neither showed in his works the smallest effect of the tragedies daily enacted around them. Indeed, Cuyp, by antithesis, emphasized the calm serenities of peace; and while his compatriots were convulsed with civil war and were suffering and dying violent deaths, he quietly depicted idealistic scenes of husbandry, with lowing herds, peaceful river views with fishing boats, and lazy summer skies, all suggestive of the tranquil beauty of the life he himself lived near the Dort. Speaking of his paintings of this picturesque stream, M. Waagen writes: "It would be impossible to describe the pervading transparency of the morning sunlight or the delicacy of the aerial perspective in the gradation of a succession of vessels lying one behind another." The present "Sunrise on the Dort" is an excellent example of these qualities so characteristic of Cuyp. 


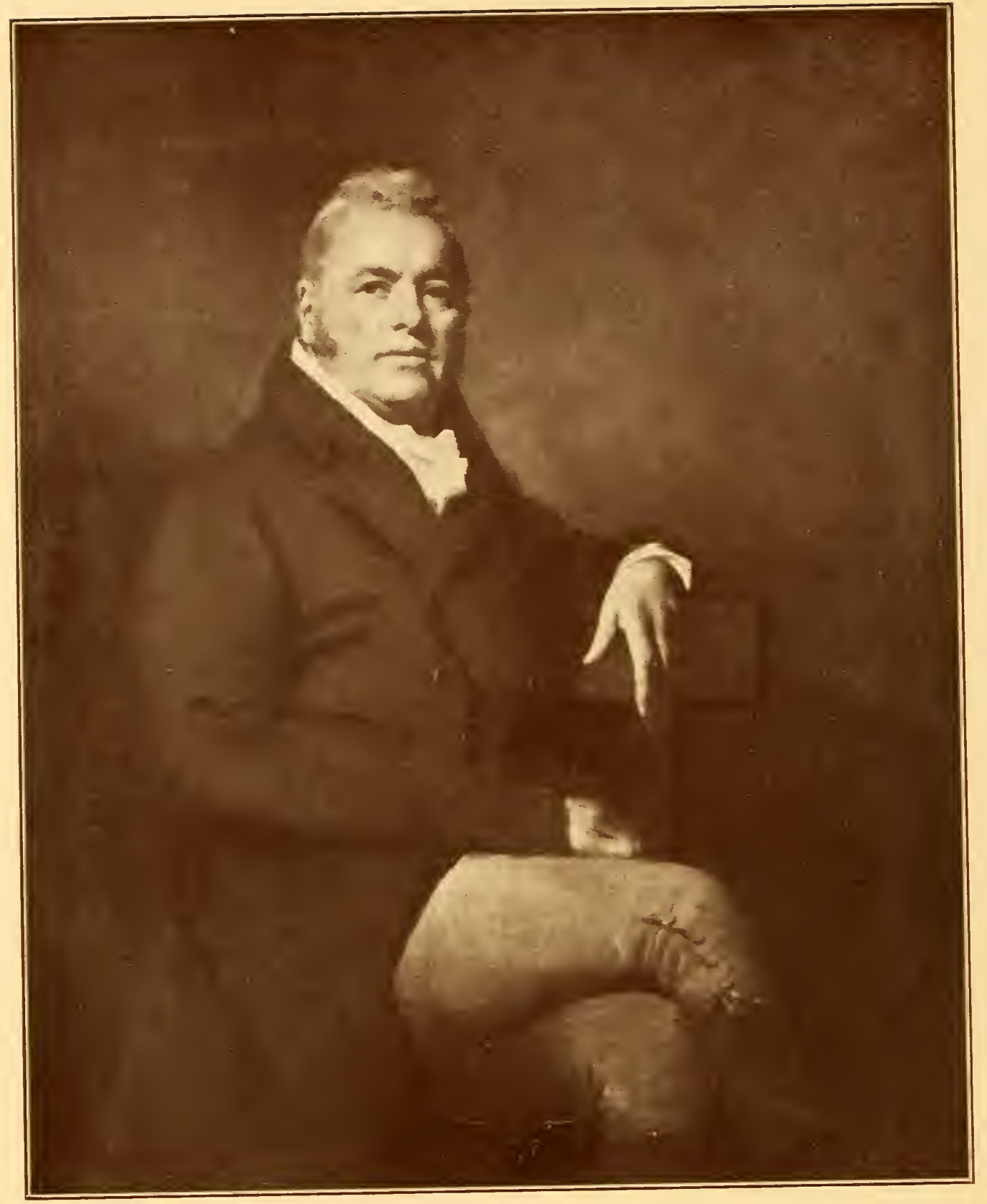




\title{
SIR HENRY RAEBURN
}

\author{
( I756-I823) \\ JAMES CRUIKSHANK \\ Canvas, 40 inches by 50 inches
}

EARLY full-length; seated on a chair; turned half
way to the right; nearly full face; knees crossed;
left arm resting on the back of the chair. Black
coat and buff knee breeches; white stock; top boots. Greenish background.

Companion picture to the portrait of Mrs. Cruikshank.

Mentioned in Armstrong's "Raeburn," i 901, p. 99.

" " James Greig's "Sir Henry Raeburn," I 9 I I,

$$
\text { p. } 42 \text {. }
$$

Previously owned by M. Maurice Kann, Paris.

Illustrated in Sedelmeyer Catalogue of Old Masters, I905, No. 88.

James Cruikshank was the eldest son of Donald Cruikshank, of Gorton, and Catherine, daughter of John Grant, of Auchterblair. He married, June, I 792, Margaret Helen, daughter of the Rev. Alex. Gerard, D.D., of Kings College, Aberdeen. Their son James was a distinguished officer and served in the Napoleonic wars with the I 8th Hussars. He married Lady Anne Lætetia Carnegie, second daughter of the seventh Earl of Northesk.-Burke's Landed Gentry. 


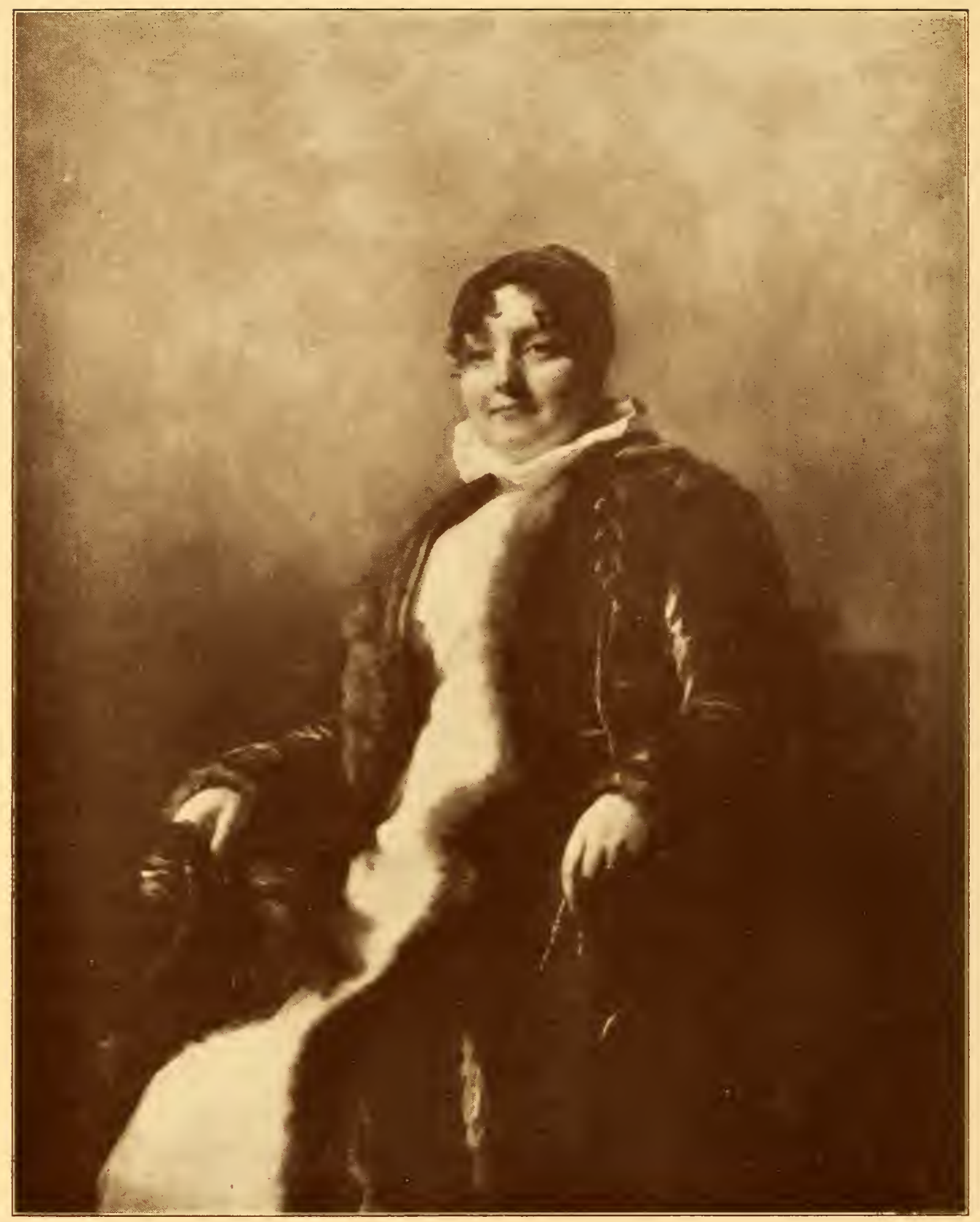




\section{SIR HENRY RAEBURN}

$$
\text { ( I756-1823) }
$$

\section{MRS. CRUIKSHANK}

Canvas, $40 \mathrm{~T} / 2$ inches by $503 / 4$ inches

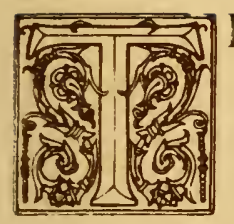

HREE-QUARTER length; seated; turned half-way to the left; each hand rests on the arm of the chair; nearly full face; eyes directed toward the spectator. Blue velvet coat edged with fur, over a plain white dress. Hair arranged in ringlets low on forehead and bound by a blue ribbon. In her right hand a blue velvet toque with ostrich feathers. Gray background.

"I cannot be far wrong in putting down the "Mrs. Cruikshank of Langley Park' to the years between $\mathrm{I}^{80} 5$ and I 808 . It is the portrait of a fat, good-humored woman of thirtyeight or forty, the sort of person the middle-aged Scot half a century ago would have called a 'soncy lass.' She wears a dark blue-gray very modern-looking velvet mantle over a white dress. Behind her she has a 'systematic' background, a wellchosen and judiciously broken tone of gray, like a background of Frans Hals. Nothing could be simpler, apparently, than the whole conception; but it is not so simple as it looks. The lady is plump enough to make her contour from chin to knee almost an unbroken line. She has no waist and too much hip; her arms are short and fat, with hands to fit them, and she has no throat; but so cleverly has the painter used his materials, that until we look into matters with the indiscreet eye of the inquiring critic we see none of this. The almost smooth expanse of white satin is so skilfully broken at the edges, the mantle is brought around in such a cleverly supplementary way, that we get a play of line which satisfies the eye without perverting fact. Especially dexterous, or sensitive, is the setting of the head. Its apparent size is reduced by prolonging the line of the ruff with a fold of the dress, on the right."-Armstrong's Raeburn, pp. 76-77. 


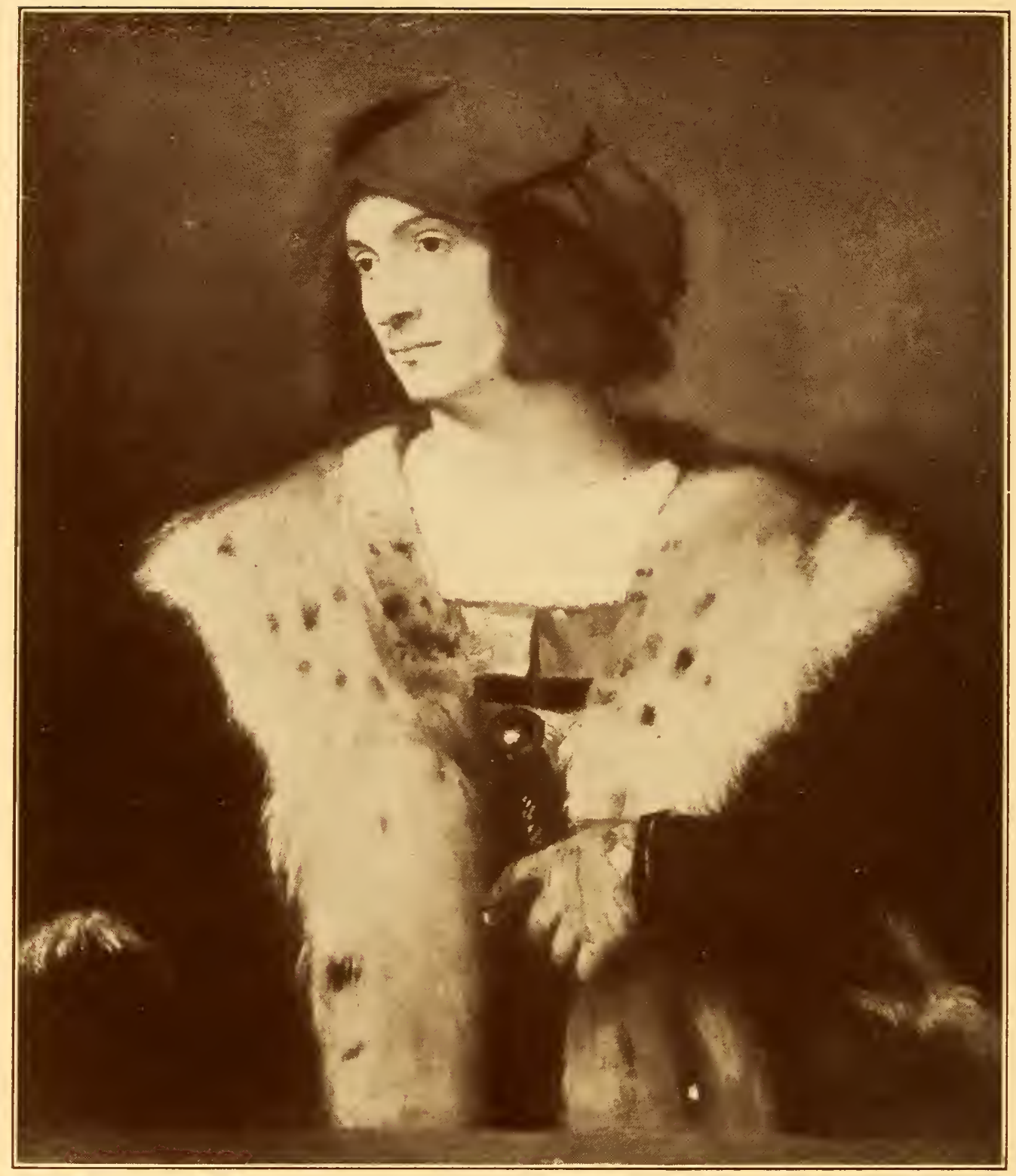




\section{TIZIANO VECELLIO (TITIAN)}

\section{( $1489-1576)$}

\section{A MAN WITH A RED CAP}

Canvas, 263/4 inches by $3 I$ inches

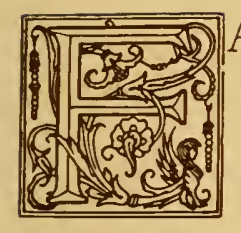

2) ACING to the front, with his head turned slightly to the left, wearing a dark cloak trimmed with gray fur, showing underneath it a yellow tunic and a white linen shirt; a red slashed cap on his head; his left hand, which is gloved, holds the hilt of his sword.

On an old label which has been taken from the back of the picture, appears the following inscription: "Undoubtedly The Portrait of Lorentius de Medicis just escaped from assassination at the time his brother was killed. See Biographical Dictionary, and the Medallion to the Preface of his life."

Exhibited at the Grafton Gallery, I909-Io.

Reproduced by I. J. Waddington, Limited, in Arundel Club Portfolio, I 906, No. I6.

Reproduced in color by the Medici Society.

Mentioned in Chas. Rickett's "Titian," pp. 45-46 (Plate XVIII.).

Illustrated in Christie's Catalogue of Important Pictures by Old Masters, June 26, i 9 I 4.

From the Collection of Arthur M. Grenfell.

$$
\text { " " " "Sir. Hugh Lane. }
$$




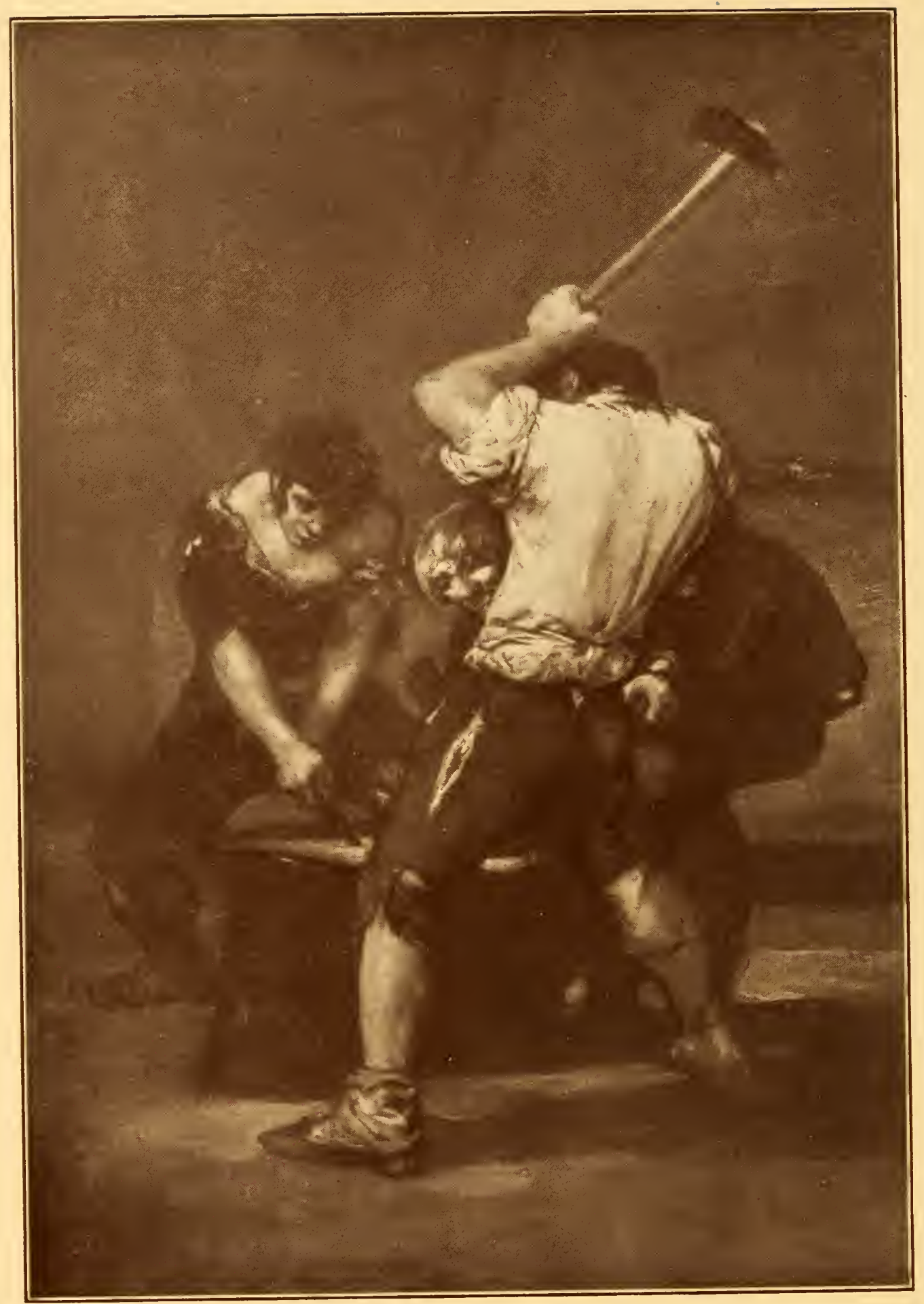




\section{FRANCISCO GOYA}

\section{( I746-1828)}

\section{THE FORGE}

Canvas, 491/2 inches by $71 \frac{1}{2}$ inches

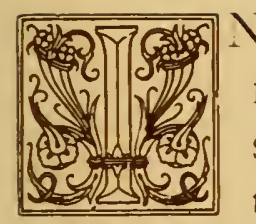

NTERIOR of a blacksmith's shop; full-length figures of three men standing around an anvil. A stalwart young man with black curly hair holds the red hot iron with the tongs, a grey-haired man with stubby beard appears to be holding a cutting-off tool, while the third man, with his back to the spectator, is vigorously wielding his sledge. At right, in the background, one can see the faintly-glowing fire of the forge. The general tone is a harmonious blending of gray, yellow, black and white - "a picture painted with genius at full pressure."

It was formerly in the collections of King Louis Philippe, and of Lord Taunton.

Francisco Jose de Goya y Lucientes was born of humble parents at Fuentetodos in Aragon, March 3oth, I $746 . \mathrm{He}$ studied under Jose Luxan Martinez, and later went to Italy where he met and fraternized with Louis David. In I 774 he returned to Spain, married and worked industriously at his art, painting a vast number of pictures of the most varied character, as well as making numerous etchings, engravings and aquatints. He died in I 828 . 


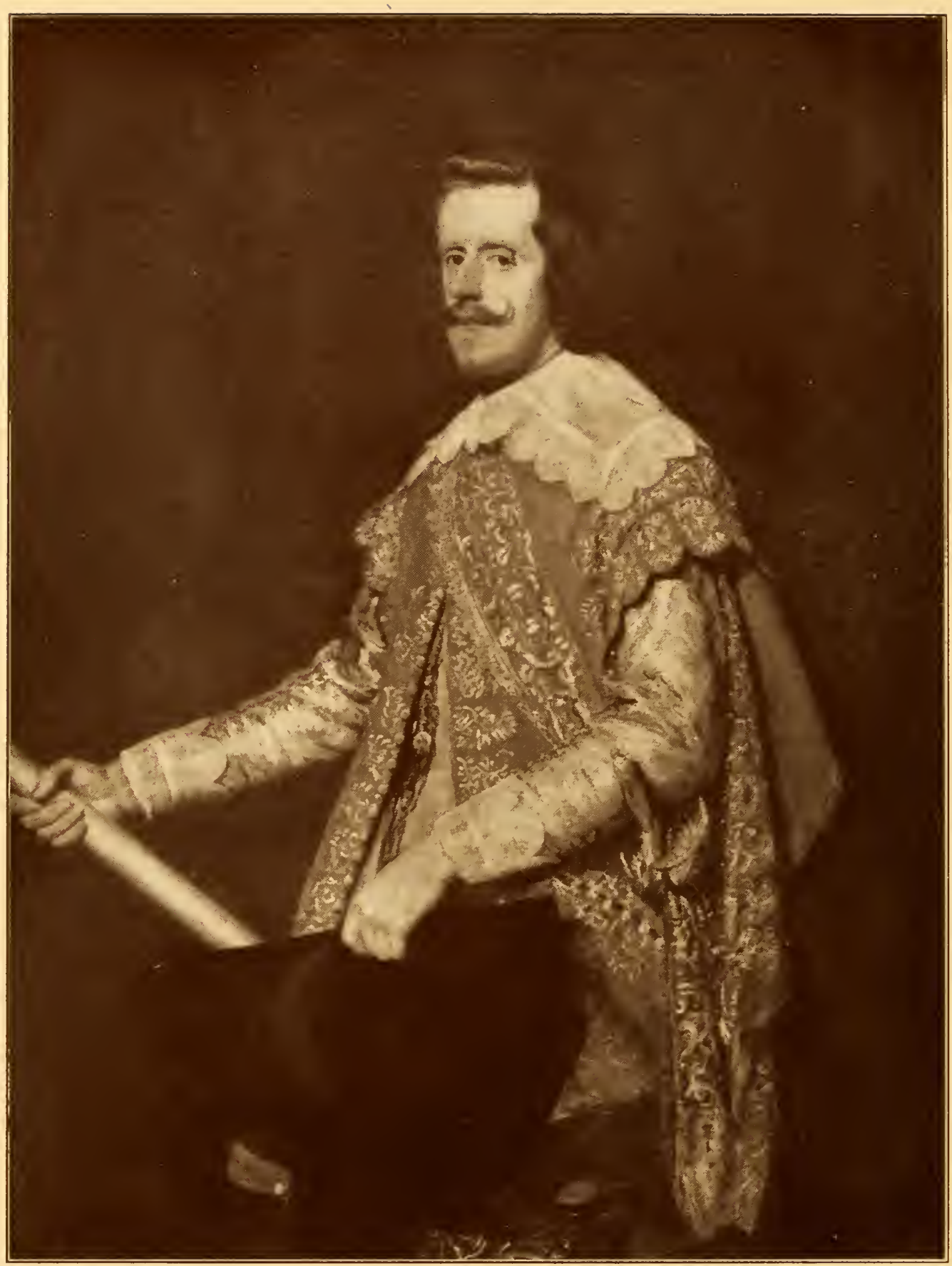




\section{( I 599-I660)}

\section{PORTRAIT OF PHILIP IV OF SPAIN}

(Known as the "Parma Velasquez")

Canvas, $383 / 4$ inches by $52 \mathrm{~T} / 2$ inches

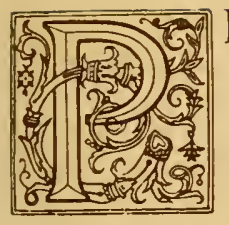

HILIP IV. was born in 1605 , and inherited the throne of Spain when he was only i 6 years old. His reign was marked by no noteworthy achievement, and his only claim to the gratitude of posterity is his patronage of Velasquez, Lope de Vega and Calderon. He has, indeed, been held responsible for the decay of Spanish political and military power. He assumed a rigid solemnity of manner in public and was seen to laugh only three times in the course of his life. In private, however, he indulged in coarse horseplay and was grossly immoral. He died in 1665.

This famous portrait was painted in I644, in Cataluna, where Philip had gone to try to raise the siege of Lérida, invested by the French. Velasquez accompanied him, and in contemporary records it is related how the King, dressed as a soldier, with "fitted hose edged with silver embroidery, sleeves of same, plain buck-jerkin, red sash edged with silver, cape of red fustian, braiding of silver embroidery, short sword and spurs of silver, falling collar, and black sombrero with crimson plumes," posed to Velasquez in a dilapidated shanty, that had to be fitted with doors and windows to make it fit for the King to stay in. The finished canvas was then "hung in the church under a canopy embroidered in gold, where much people congregated to see it." The record adds that "copies thereof are already being made" —of which probably the fine one in Dulwich, England, is an example.

Its subsequent history is known. It was sent by Ferdinand VI., King of Spain, to the palace of his step-brother, the Grand Duke of Parma, in whose family it remained until recent times. It was sold by Prince Elias, son of Duke Robert, to Messrs. Agnew, of London. 


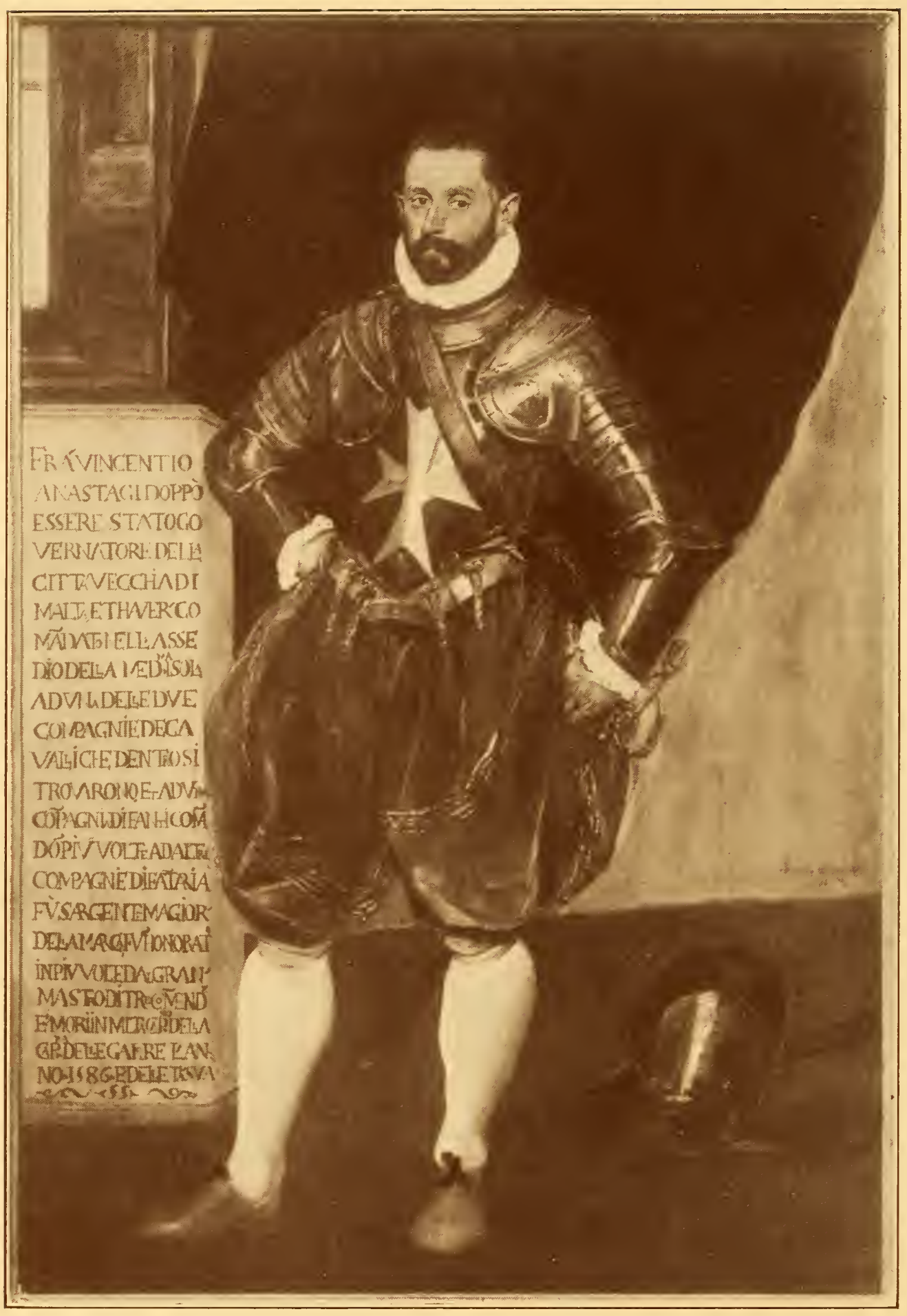




\section{"EL GRECO"}

(Dominico Theotocopuli)

$$
\text { ( } 1545 ?-1614 ? \text { ) }
$$

\section{FRA VINCENTIO ANASTAGI, GOVERNOR OF CITTA VECCHIA DURING THE SIEGE OF MALTA}

Canvas, $493 / 4$ inches by 74 inches

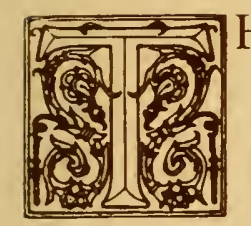

$\mathrm{HE}$ fine full-length portrait of Vincentio Anastagi, in a steel cuirass, green velvet breeches and white hose, one of the stout knights of St. John, who kept the outpost of Christendom against the Turk with the Grandmaster Giovanni di Valetta, is probably the best specimen of El Greco's pencil in England."-Quoted from Stirling's Annals of Artists of Spain, I., 357.

The first authenticated portrait by El Greco, with its unmistakable signature in Greek characters, is said by Mr. Henneker-Heaton to be that of the artist's fellow-countryman and patron, Julio Clovio. Mr. Heaton says that "next comes a portrait of Vincentio Anastagi," the present painting.

In his Handbook of Painting, Sir Edmund Head describes this as "a very singular portrait," "thoroughly Venetian in its character" - a suggestion borne out by the long Italian inscription which it bears on a pedestal, and which sets forth the various commands of Anastagi during the stirring times in which he lived.

The portrait was known to art students in early times, but was lost sight of for a time. Henniker Heaton refers to Stirling's mention of the painting, but says "its present whereabouts cannot be traced." Later, Sir Edmund Head (Handbook of Painting, II., 83) notes that it "has lately been brought to England by Mr. Conyngham," and from him it passed into the possession of the late Baron Taunton. It is mentioned or described in several other works than those cited. 


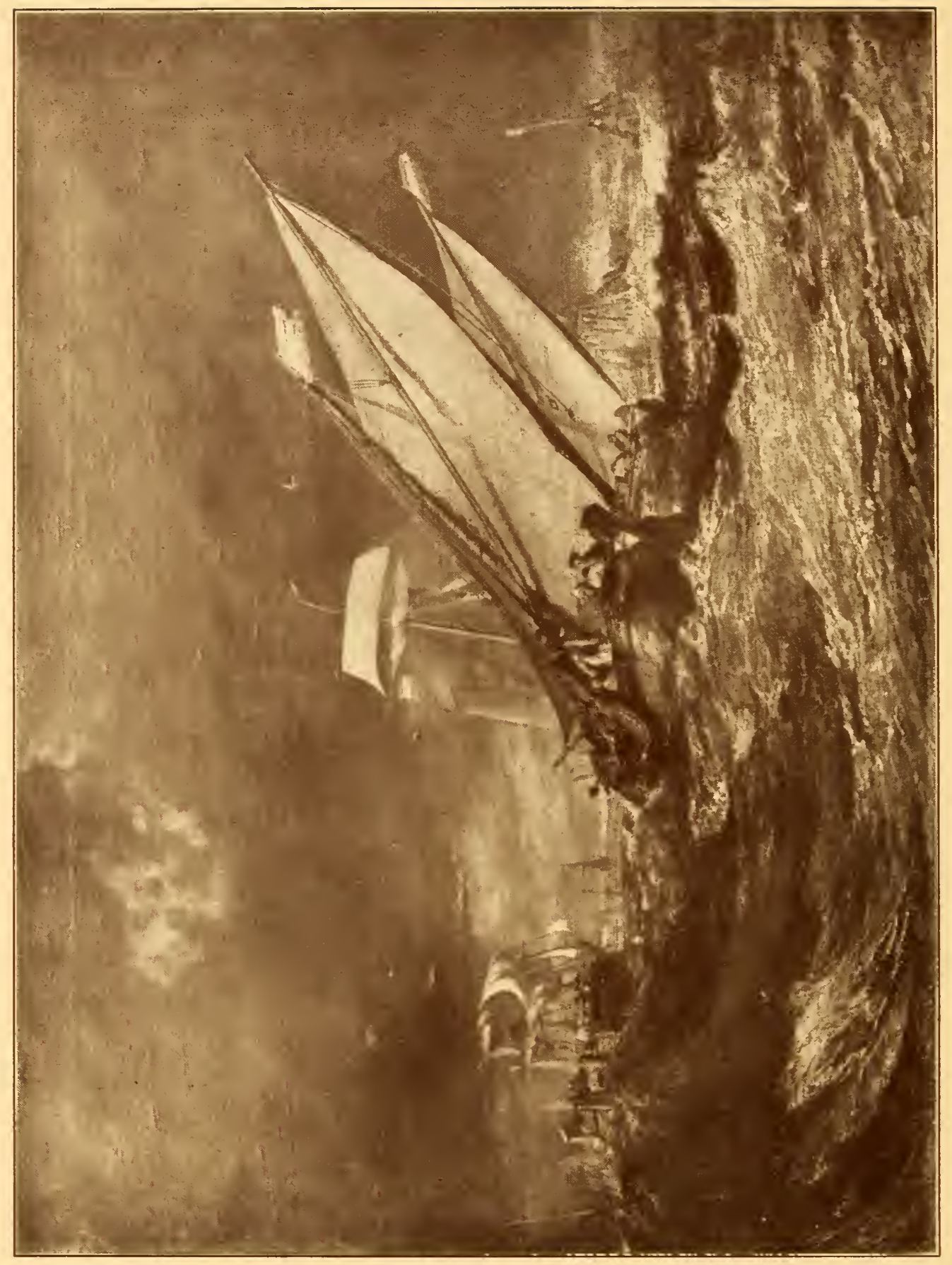




\section{J. M. W. TURNER, R.A.}

$$
\text { ( I775-I85I) }
$$

\section{FISHING BOATS ENTERING CALAIS HARBOUR}

\section{Canvas, 38 inches by 28 inches}

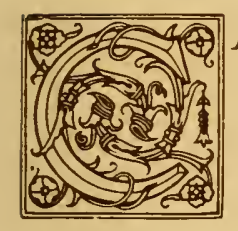

ALAIS was one of the spots that fascinated Turner when he first visited the Continent, and he more than once found there material and inspiration. In

this picture two fishing boats, with sprit-sail rig and brown sails, surge through the foam-covered sea, and make for the quiet waters of the inner harbor. It is evidently an anxious moment for the crews; they are full of animation and excitement. The impression of rush and motion is admirably conveyed. To the extreme right is a beacon marking the mouth of the harbor on one side. In the distance are the houses of the town and the spires of the churches, and to the left the other arm of the pier, behind which vessels are lying with their sails partly unfurled. The sky is heavy and lowering, and dark with menacing clouds that tell of storm and rain.-Catalogue of Coates Collection.

In the Burlington Mag., XI., p. 398, C. J. Holmes describes this Turner as "powerful in effect, superbly painted, and filled with the closest observation of nature . . . a masterpiece superbly conceived, superbly observed and painted with unrivalled power and science."

It was engraved by Turner himself and is mentioned in many books on art. It was in the Royal Academy in I 884 , and has also been exhibited at the Guild Hall, at the Glasgow International Exhibition and other places. It has been in the collections of Henry Drake, London, and of Archibald Coates, Paisley. 


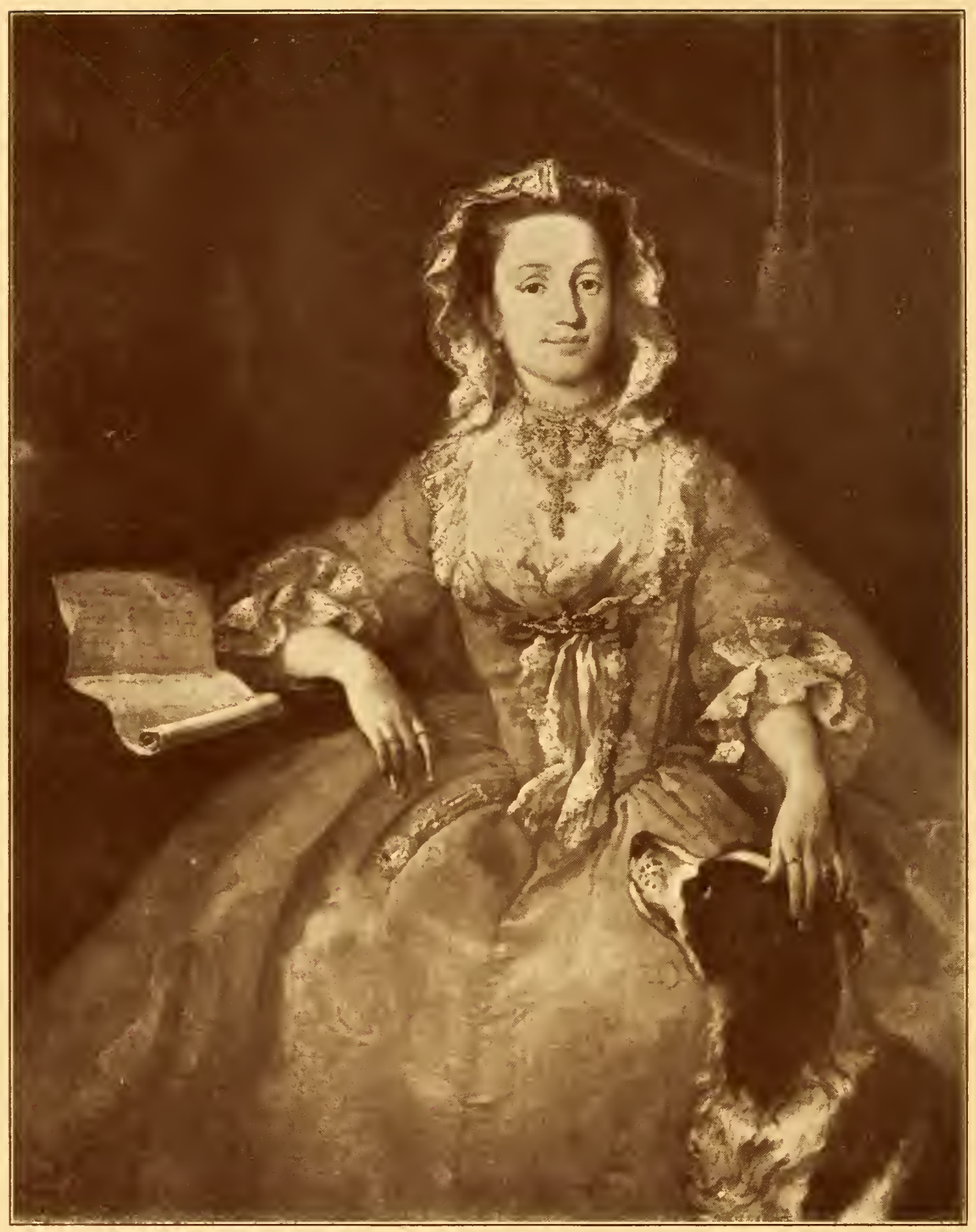




\title{
WILLIAM HOGARTH
}

\section{( г697-г т64) \\ MISS MARY EDWARDS}

Canvas, 377/8 inches by $493 / 8$ inches

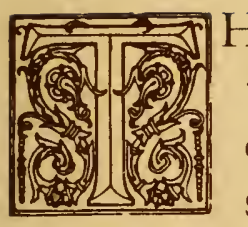

HREE-QUARTER length, seated, left hand lightly touching the head of a retriever, right arm resting on a table; red dress with low lace-trimmed corsage. Jeweled cross and elaborate pendants hang from a string of pearls around the neck. Over the head a lace mantilla-like shawl. On the table a large open scroll, containing a poem, appealing to Englishmen to cherish the laws, rights and liberties "delivered down" to them "from age to age by their renowned forefathers."
\end{abstract}

Mary Edwards, whose strong personality is so vividly portrayed by Hogarth in this portrait, was one of the most interesting women of her time. A great heiress, she was clandestinely married to a fortune-hunter, but saved her estate for her son by the heroic recourse of repudiating her marriage and declaring her child illegitimate. She was a daughter of Francis Edwards, Esq., and Anna Margarette Vernatti, his wife. Born I 705, she married Lord Anne Hamilton in I73 I, and died I 743. Her only son, Gerard Anne Edwards, of Welham Grove, Co. Leicester, married Jane, daughter of Baptist Noel, fourth Earl of Gainsborough. By royal license in I 798, their son, Gerard Noel Edwards, assumed the surname and arms of Noel, and subsequently succeeded to his father-in-law's baronetcy as Sir Gerard Noel Noel. In I 84 I Charles Noel, descendant of the foregoing, was created Earl of Gainsborough.

Hogarth's "Taste in High Life" was painted for Miss Edwards.

The portrait is from the collection of Col. IV. F. N. Noel, of Stardens, Newent, Gloucestershire. 


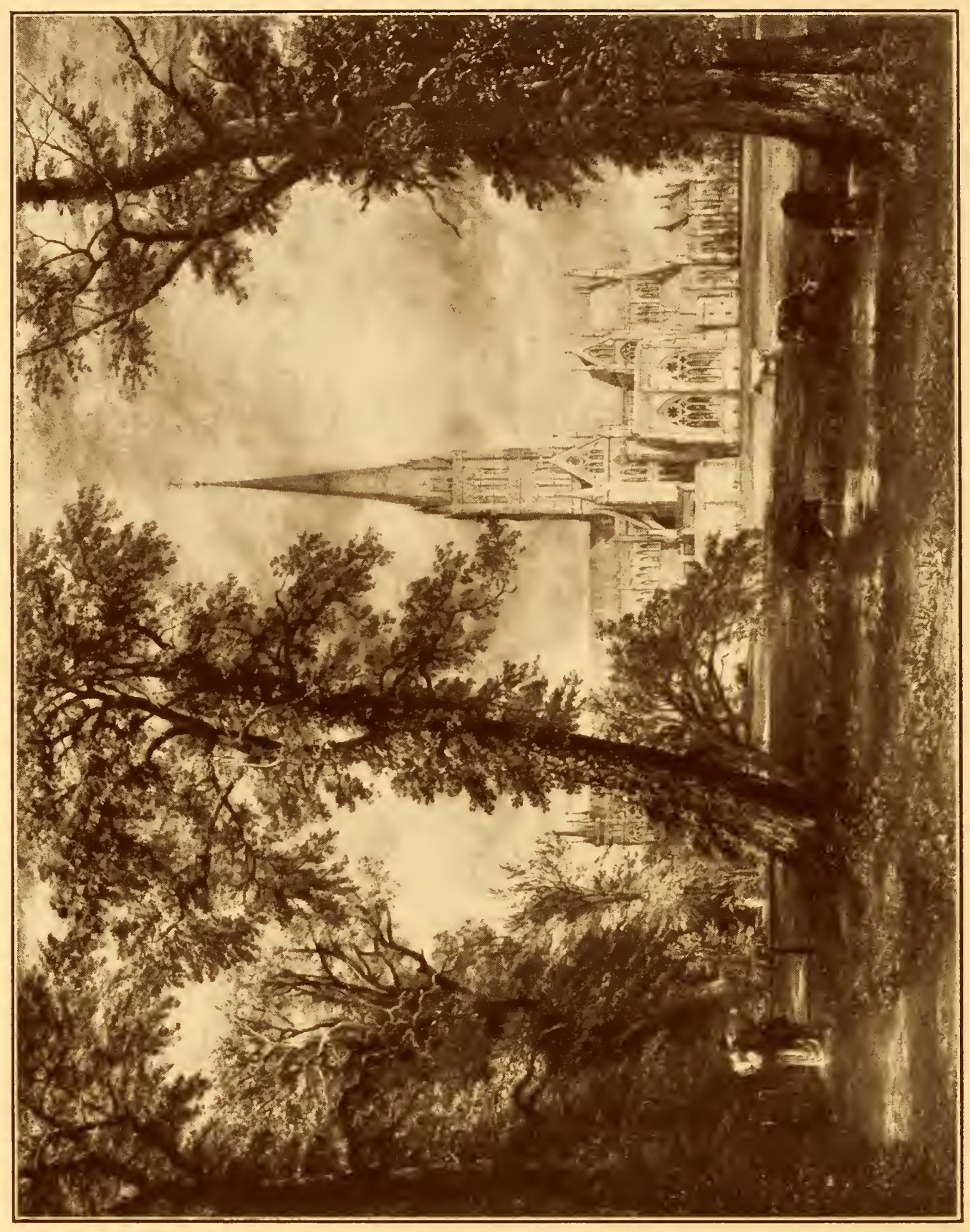




\section{JOHN CONSTABLE, R.A.}

\section{( $1776-1837)$}

\section{SALISBURY CATHEDRAL}

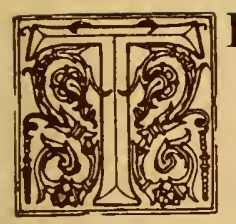

HE beautiful cathedral at Salisbury, with its picturesque setting of ancient trees, was a favorite subject with Constable. He sketched it from all sides and in all lights, and made a number of paintings of it. Of these only three are of prime importance: the present one, the one from the same point of view, but slightly smaller, now in the South Kensington Museum, and a very large painting showing the Cathedral from the meadows. The two firstmentioned were executed on order for the Bishop of Salisbury, Dr. Fisher, in I 822 . In a letter to Constable, dated August 3d, I 822, Bishop Fisher writes:- "My daughter Elizabeth is about to change her situation, and try whether she cannot perform the duties of a wife as well as she has done those of a daughter. She wishes to have in her house in London a recollection of Salisbury; I mean, therefore, to give her a picture, and I must beg of you either to finish the first sketch of my picture, or to make a copy of the small size. I wish to have a more serene sky."

The daughter thus referred to in the Bishop's letter was Elizabeth; and in October, I823, she was married to John Mirehouse, an eminent barrister, who for many years filled the office of common sergeant of London. He died in 1850 , leaving a son and several daughters. In 1862 the painting was sent by Mrs. Mirehouse to the International Exhibition, and two years later it was sold to Mr. Locke H. Agnew. It then passed into the possession of Stephen G. Holland, of London.

The figures in the foreground probably represent Bishop Fisher and the daughter for whom the painting was made.

The picture is mentioned in all the books written about the artist and has been frequently exhibited. 


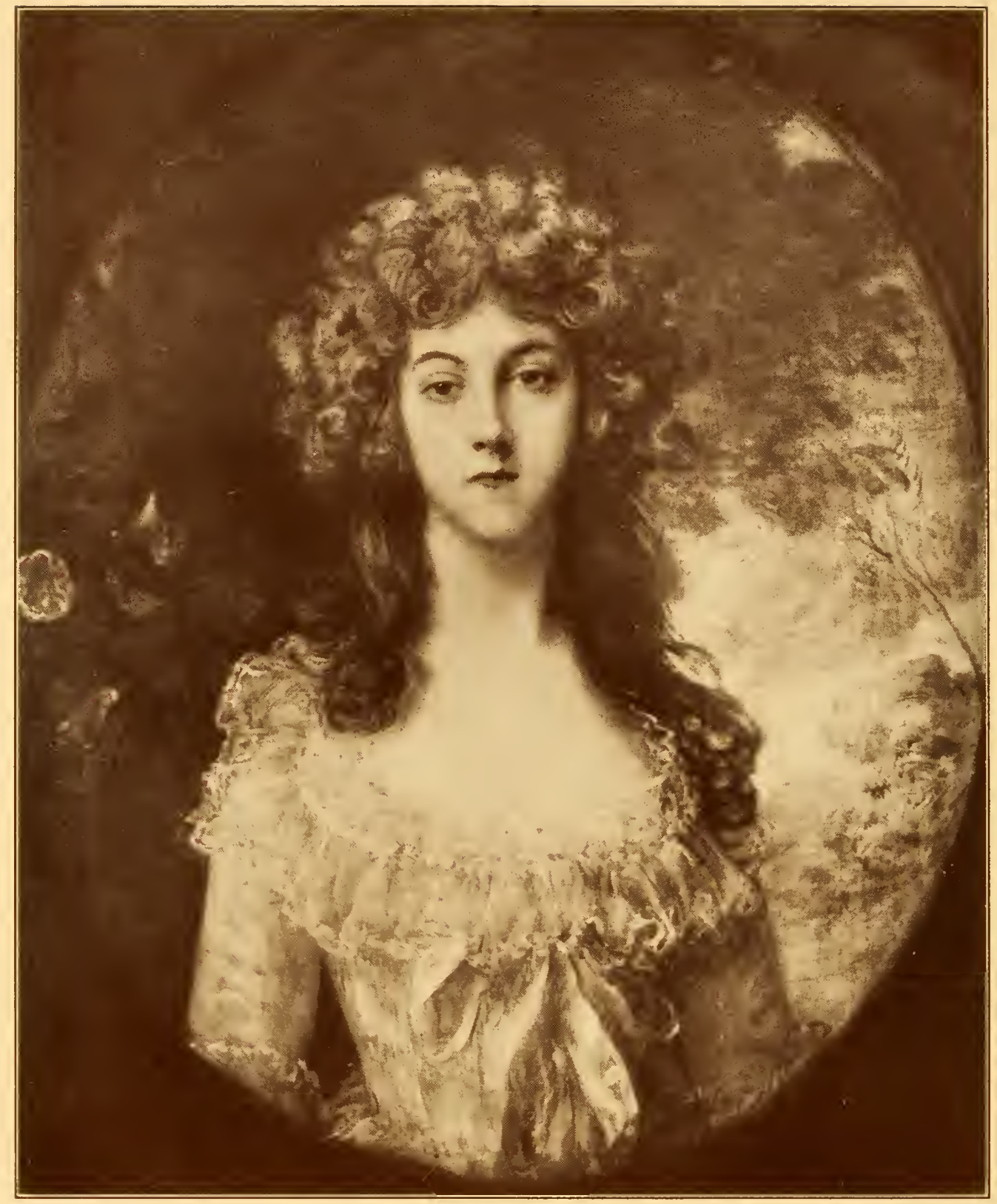


THOMAS GAINSBOROUGH, R.A.

( I727-I 788 )

MRS. HATCHETT

Canvas, 24\%1/2 inches by 205/8 inches

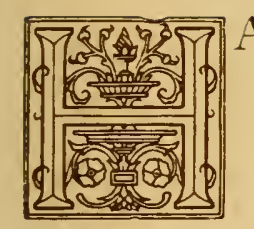

ALF-LENGTH. Standing; full face, eyes directed toward the spectator. Low neck, yellowish dress. Dark powdered hair arranged in ringlets, some of which are falling down on her shoulders. Landscape background, on the left a spray of convolvulus. Painted oval.

This portrait of Mrs. Hatchett was painted in 1786 , immediately before her marriage with Chas. Hatchett of Mount Claire, Roehampton, son of John Hatchett, coach builder of Long Acre, London. He was descended from old French Noblesse, but better known in England as a literary and scientific man, a friend of Sir Joseph Banks, Mr. Canning and the book-collecting Lord Spencer, a founder of the Linnean Society and the Royal Institution. Hatchett died Feb. I0, I 847 , at Bellevue House, Chelsea, aged 82. He contributed many papers to the scientific publications of his day and discovered the metal columbium or tantalum.

The lady painted was (like the Hatchetts) of a Huguenot family, which disguised itself under the English name of Collick, but the real name is lost. She was I 7 when Gainsborough painted her. He used to spend many evenings at her father's house, and was won by the young lady's extraordinary musical genius. She was a pupil of Clementi, who pronounced her the first non-professional performer in England.

Gainsborough asked to paint her portrait, and declared he would do his best; he sent it home a wedding gift from the painter.

It has been in the collections of Alfred Rothschild, Chas. Wertheimer and Archibald Coates of Paisley. 


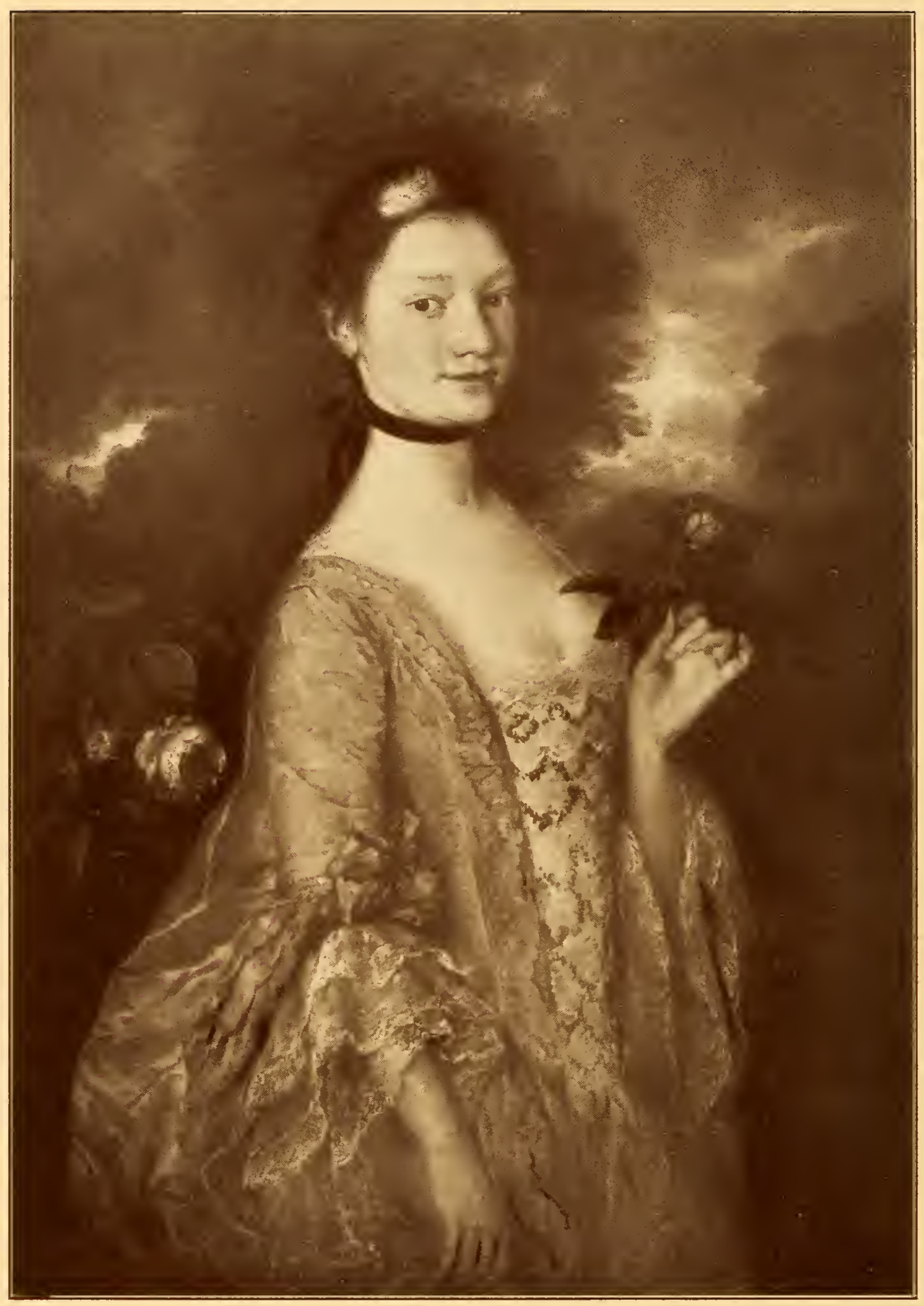


THOMAS GAINSBOROUGH, R.A.

\section{( I727-I 788 ) \\ LADY INNES}

Canvas, 283/8 inches by 40 inches

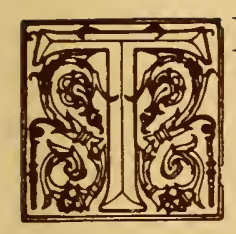

HREE-QUARTER length. Standing, turned halfway to the right; the eyes are directed toward the spectator. In her left hand she holds a rosebud, ing a fold of her robe. Blue taffeta dress, trimmed with lace; narrow black velvet band round her throat, and small white plume in her hair. Landscape background with roses on the left.

Sarah, daughter and heiress of Thomas Hodges of Ipswich, first wife of Sir William Innes, eighth Bart., captain of the Second Light Dragoons. She died May 15, I770, leaving two daughters.

Rimber's Baronetage of $\mathrm{I} 77 \mathrm{I}$ shows that William Innes, the husband of this lady, succeeded his brother, Sir Charles Innes of Balveny, Bart., in 1763 , and married secondly, in I774, a Miss Parsons. His two daughters by his first wife, were living in the late thirties of last century, and apparently died unmarried.

The portrait was formerly in the J. H. Dunn collection in London. It is a work of the Ipswich period, hitherto unrecorded in works on Gainsborough, and is of special interest because of its color-scheme, showing that at this early datelong prior to the painting of the "Blue Boy"-Gainsborough had run counter to Sir Joshua Reynolds' aversion to blue as the predominant note in a portrait. 


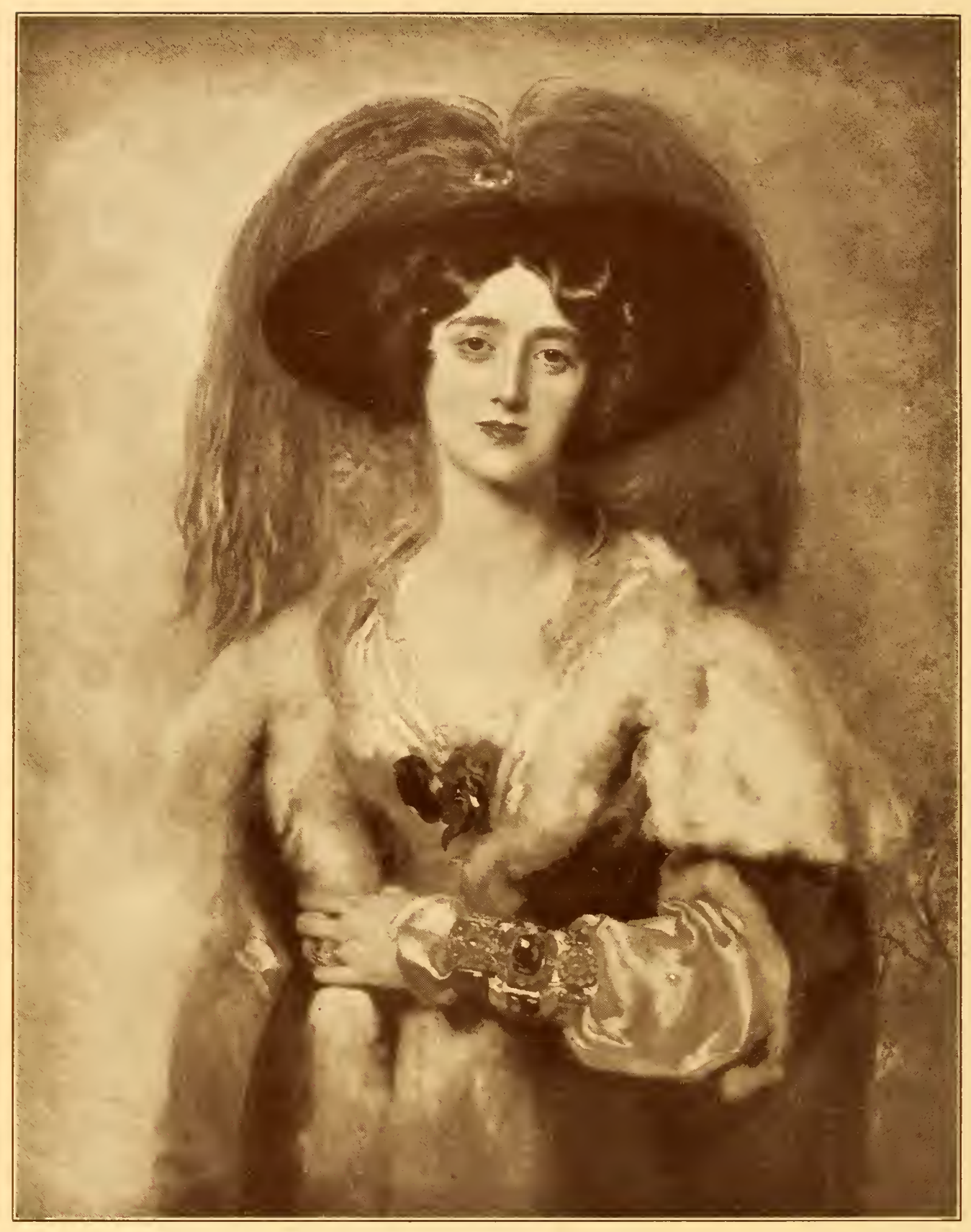


SIR THOMAS LAWRENCE, P.R.A.

( г $769-1830)$

\section{LADY JULIA PEEL}

Canv'as, 28 inches by 36 inches

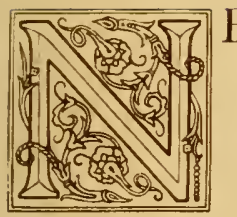

EARLY three-quarter length, standing, full face. Wears a dark purple cloak trimmed with white fur over a low neck white satin gown. At her breast she wears a rose. Large black hat trimmed with red bird of paradise feathers. Hair parted and worn low over the temples. Her left arm in front of her, holds edge of cloak.

Julia, youngest daughter of General Sir John Floyd, Bart., married Sir Robert Peel, i 820 , and died I 859.

"This is a superb work, rich in color, and with a charm which places its author on a level with the painter of the well-known portrait of Rubens' wife, called 'Le Chapeau de Paille,' now in the National Gallery, which certainly had inspired Lawrence when he painted this portrait of Lady Peel, and which he had probably studied in Sir Robert's Gallery at Dayton."-Quoted from Lord Ronald Sutherland Gower. The portrait is repeatedly referred to in eulogistic terms in Sir Robert Peel's letters. It has been frequently engraved, exhibited and mentioned in books, and was formerly in the collections of Sir Robert Peel, London, and M. S. Barboc, Paris.

"Though in her own phrase 'no politician,' Lady Peel became in time," says her son George, "the closest or the only companion of the statesman in his most inmost thoughts." They had two daughters and five sons. Four of the sons attained distinction, the youngest having been speaker of the House of Commons from i 884 to I 895 , and was created Viscount Peel on his retirement from office. An older brother, Sir William Peel, V.C., K.C.B., accompanied Lord Clyde to the relief of Lucknow and was so severely wounded there that he died soon after. 


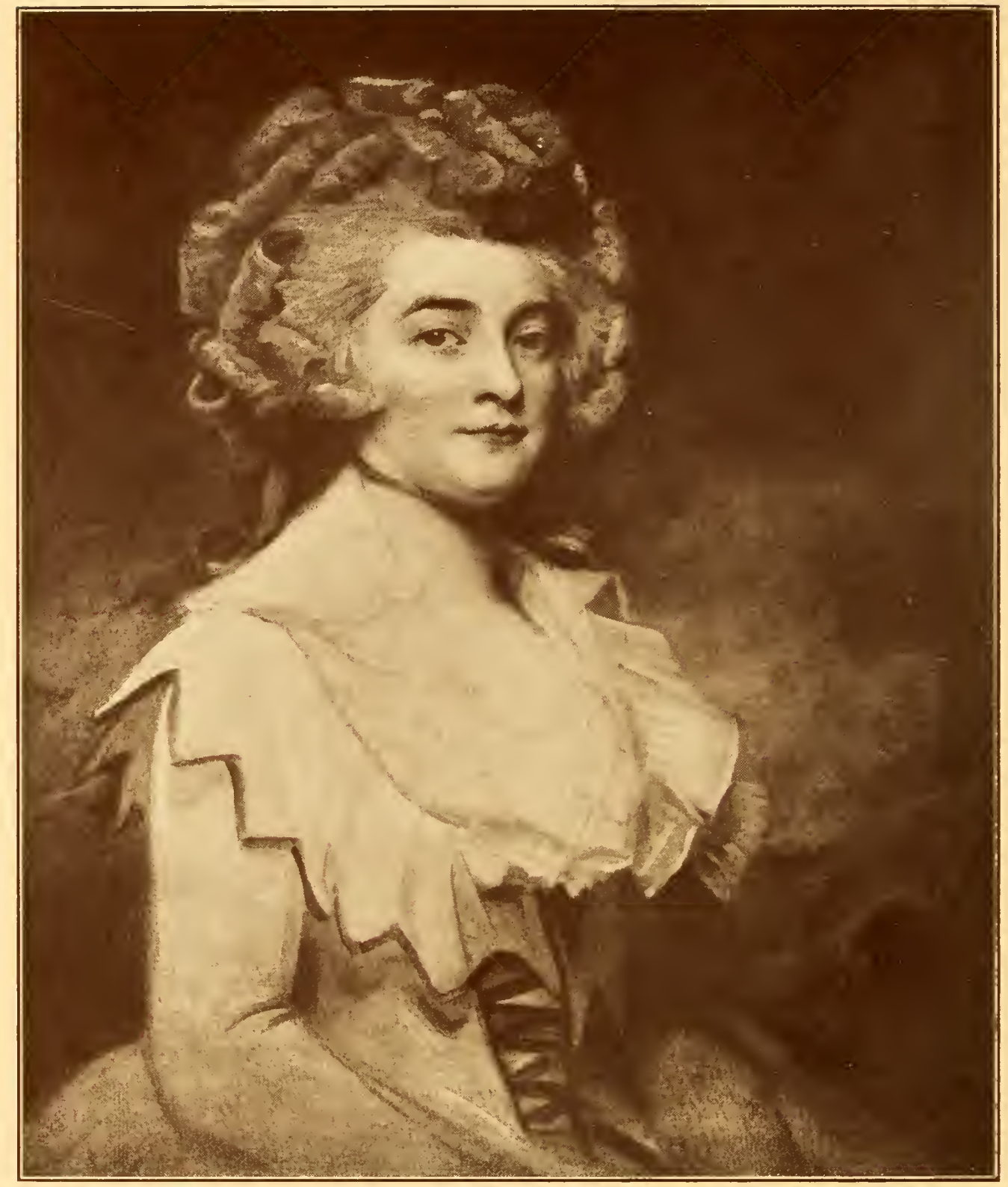




\section{GEORGE ROMNEY}

\section{( I734-I802) \\ MARY FINCH-HATTON \\ Canvas, 25 inches by 30 inches}

ALF-LENGTH, nearly full face, dressed in a white
muslin gown edged with blue. Her powdered hair
is arranged in many curls, while some of it falls
down her back.

She was the daughter of Sir John Finch Hatton, of Long Stanton Hall, near Cambridge, and wife of Hale Wortham, Esq., of Royston, Herts.

This portrait was painted in 1788 , as indicated in the entry in Romney's ledger:-

\section{"Hatton (or Hotton) Miss \\ 28 Wimpole Street \\ Three-quarters.}

Sittings, \&c; I 788, April I, 5, I 2, I 4, I 7. Sent to Lady Hatton's, Long Stanton, Cambridgeshire, Oct. I, I 788 . I 788 , Oct. 6, received of Mr. Daws for Mrs. Hatton, 3-qrs. £26. Ios."

From Humphry Ward's Work on Romney, Vol. II., p. 73, Catalogue Raisonné.

This picture comes from the family.

Exhibited at the Boston Museum of Fine Arts, I9 Io.

The Finch-Hattons were descended from the Earls of IVinchilsea and Nottingham. Edward, the fifth son of Daniel Finch, second Earl of Nottingham and sixth Earl of Winchilsea, assumed, in 1764 , the additional name of Hatton under the will of his aunt Elizabeth, daughter of Christopher, Viscount Hatton. 


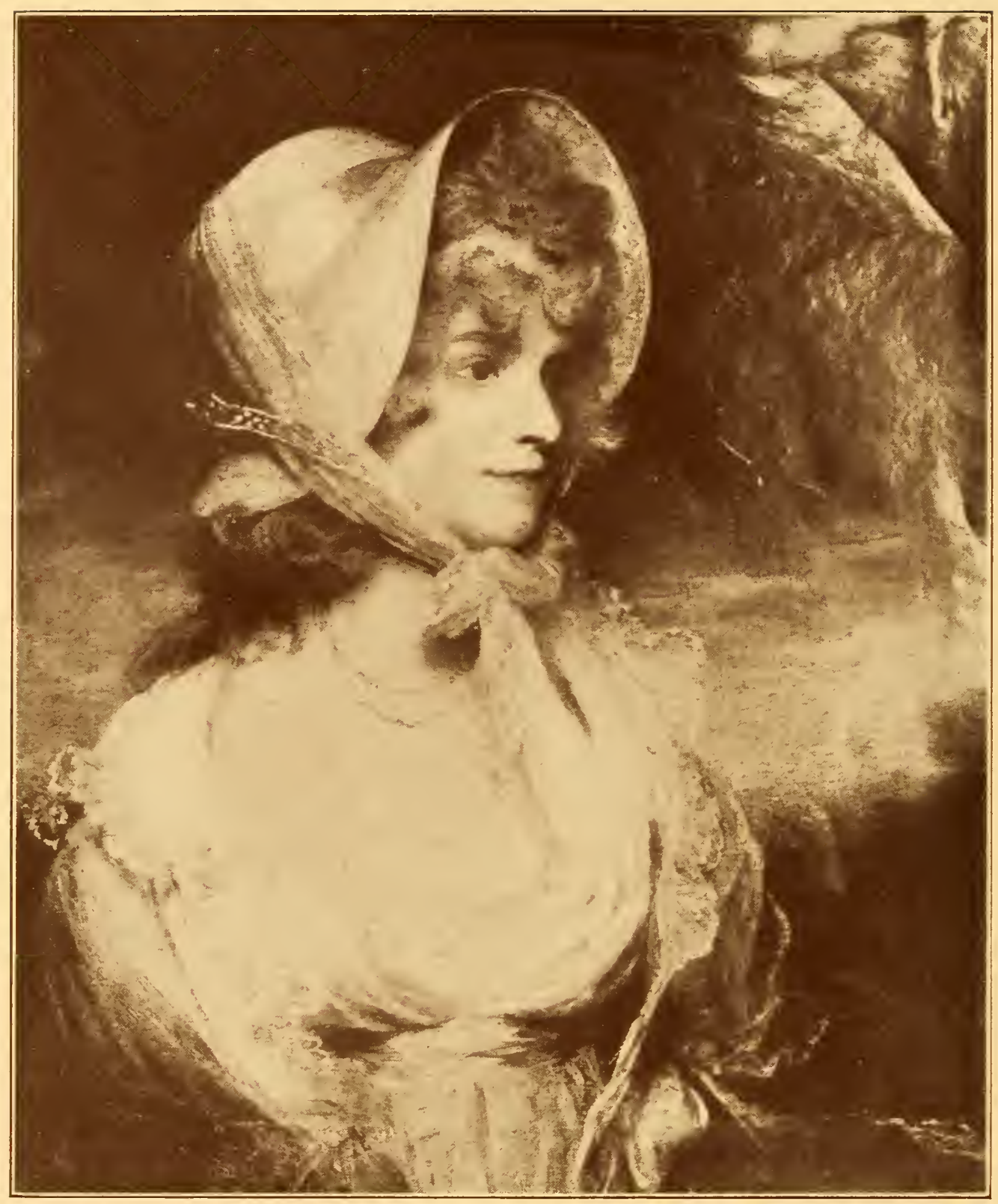


JOHN HOPPNER, R.A.

\section{( $1758-1810)$ \\ MIISS BYNG}

Cantas, 25 inches by 30 inches

EARLY half-length, face turned to the left. dressed in a low neck white gown, with yellow ribbon around the waist. On her head she wears a straw hat, fitting close over the ears by means of a white scarf tied in a bow around the neck. Her hair hangs loose down her back.

Engraved in mezzotint recently by J. B. Pratt, I $6 \times 193 / 4$.

This picture comes from the family.

Exhibited at the Boston Museum of Fine Arts, I9IO.

Photogravure following p. 37 of "John Hoppner, R.A.," by Wm. McKay and WV. Roberts, London, I909.

In text on above page:

"As the lady in this portrait is described as the "daughter of Admiral Byng,' she must have been Lucy Elizabeth, daughter of Vice-Admiral George Byng (who succeeded his father as sixth Viscount Torrington in Jan., I 8 I3), born I Ith Jan., I 794; married 28th July, I 836, the Rev. John Lukin (son of the Dean of Wells) ; died 2d April, I $875 . "$

In Burke's Peerage it is stated that Miss Byng's mother was the daughter of Philip Langmead, Member of Parliament for Plymouth. The artist died when the young lady was only sixteen, and she did not marry until she was over forty. Her father was not the Admiral Byng who was shot for alleged cowardice.

John Hoppner, born at Whitechapel, London, April 4, I 758 , died there Jan. 23, I 8 I o. When young was a chorister in the Royal Chapel, but in 1775 became a pupil of the Royal Academy, and by the patronage of the Prince of Wales became a fashionable portrait painter, finding a rival only in Lawrence. In 1793 became an A.R.A., and in I 795 R.A. 


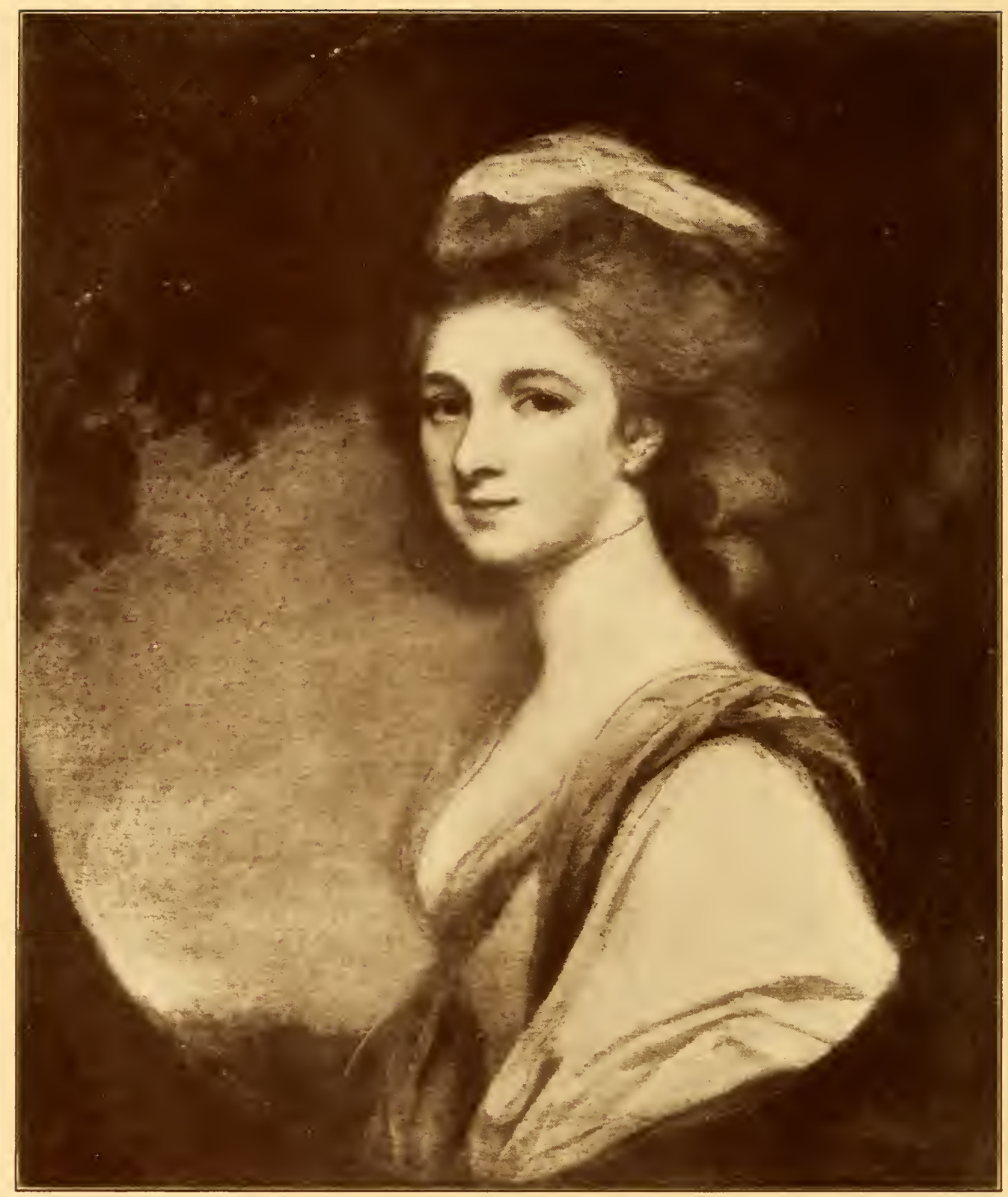




\section{GEORGE ROMNEY}

\section{( I 734-I802)}

\section{MISS HARFORD}

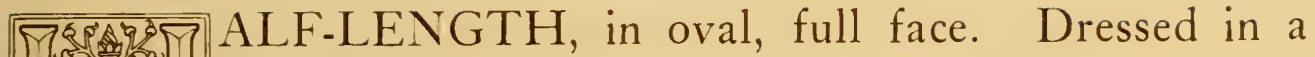
9. low neck, white muslin gown, with brown scarf about the neck and over her shoulders. Wears a pearl necklace. On her head a white cap.

Frances Mary was the natural daughter of Frederick Calvert, sixth Lord Baltimore; she married, July $2 \mathrm{I}, \mathrm{I} 784$, as his first wife, the Hon. Frederick William Wyndham ( I 763I 828 ), youngest son of the second Earl of Egremont. This lady's eldest son became fourth Earl of Egremont in November, I 837, and was afterwards first Duke of Leconfield.

Harford County, in Maryland, takes its name from this young lady's brother, who was also an illegitimate child of Lord Baltimore. Their mother was a Mrs. Hester Wheeland.

This erratic nobleman, born in I73I, married Diana Egerton, youngest daughter of the Duke of Bridgewater, but continued the wild, licentious life which, as a bachelor, had made his name a by-word in a society not overburdened with morals. In 1768 he was tried at Kingston on a vile charge, but acquitted. He lived thereafter mostly abroad, and died at Naples in I 77 I, without legitimate children. The title became extinct on his death, and by his will he bequeathed the province of Maryland, in America, to Henry Harford, a child. $\mathrm{He}$ also bequeathed 30,000 pounds to Miss Harford, the subject of the present portrait, besides annuities for life to her and her mother. The residuary property, which was very large, was left to trustees to pay to Henry Harford and sister.

As wife of Frederick William Wyndham, Miss Harford seems to have overcome the disadvantages of her irregular birth, and as the Countess of Egremont became the mother of four children, all more or less distinguished. She died in I 876 .

Collections of Earl of Egremont and Mr. Archibald Coates. 


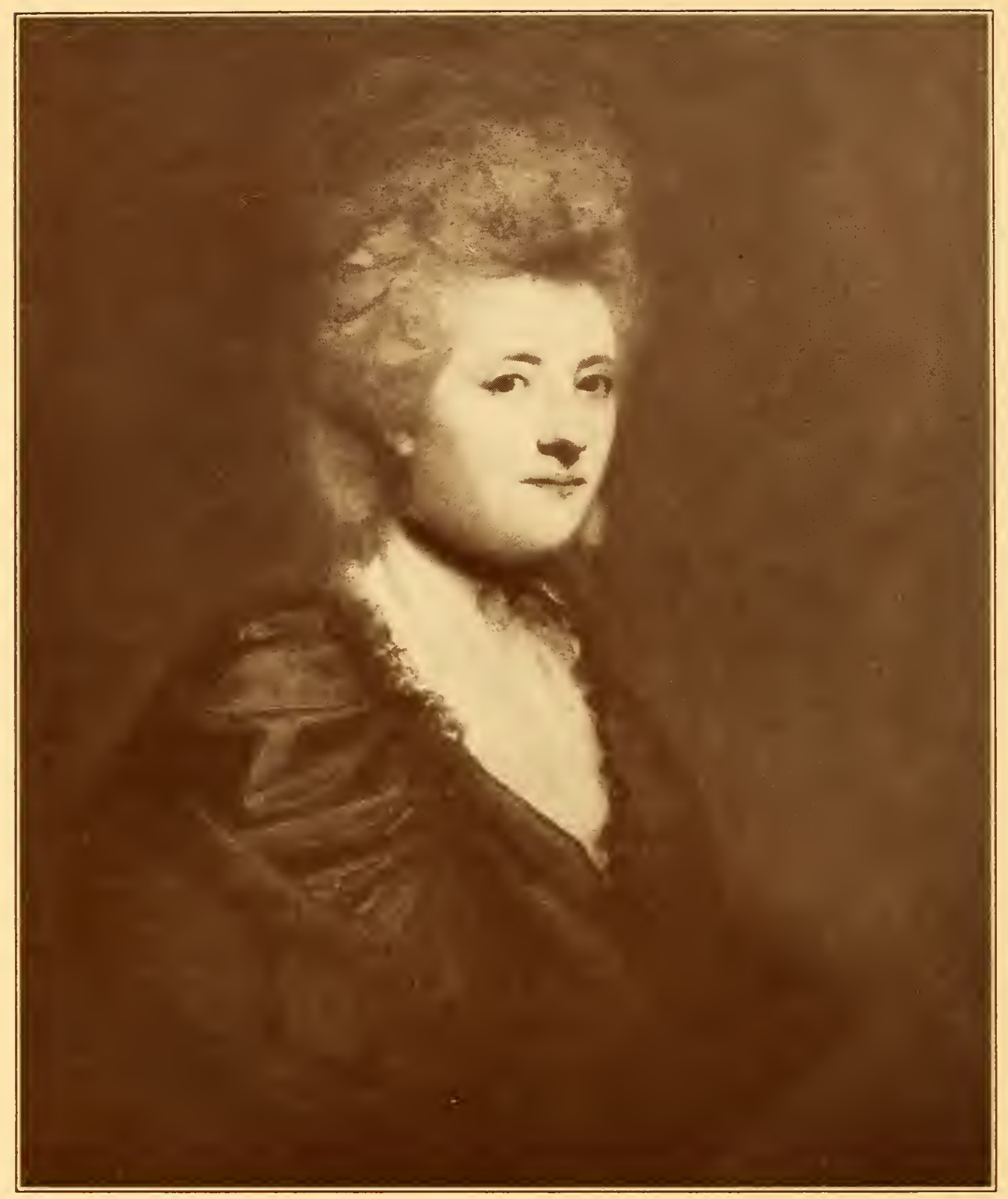


SIR JOSHUA REYNOLDS, P.R.A.

( I723-I792)

\section{LADY MARGARET BEAUMION'T}

75s ALF-LENGTH in oval, nearly full face turned to left, black dress, white muslin around the neck with a blue ribbon.

Margaret, daughter of John Willes of Astrop, Northampton, and granddaughter of Lord Chief Justice Willes. Married, May 6, I 778, Sir George Howland Beaumont, serenth Bart., died in the year 1829 .

This portrait was painted in 1779 or 1780 , and is mentioned in Leslie \& Taylor's book on Reynolds, where it is said: "Some of his most charming female heads are of this period, as Lady Beaumont, the beautiful wife of his friend Sir George.' Lord Ronald Sutherland Gower, F.S.A., says in part in his book on Sir Joshua, p. S6: "Two beautiful ladies' portraits by Reynolds belong to this year, that of Lady Beaumont, wife of the artistic Baronet, and that of Mrs. Payne Galway." Sir Walter Armstrong, in his work on Reynolds, p. i i 8, also mentions this portrait, and that of Sir George Beaumont in his Index, p. I93, and speaks of Lady Beaumont's portrait as being exhibited in 1780 , the year that saw the transfer of the Academy Exhibition to its new home in Somerset House.

It was engraved by J. R. Smith in I 780 , and by S. IV. Reynolds, later.

Besides being seen at the Royal Academy in 1780 , it was exhibited at the British Institute in I 813 , and again in I 858 . In 1867 it was in the National Portrait Exhibition, and in the Grosvenor Gallery in $x 884$.

The picture comes from the family.

"The lady was famed for the exquisite courtesy and tact with which she dispensed her husband's liberal hospitalities to artists and for the genuine kindness which, carrying out his chief aim, she was wont to extend to the younger and less firmly established members of the fraternity."-Claude Phillips. 


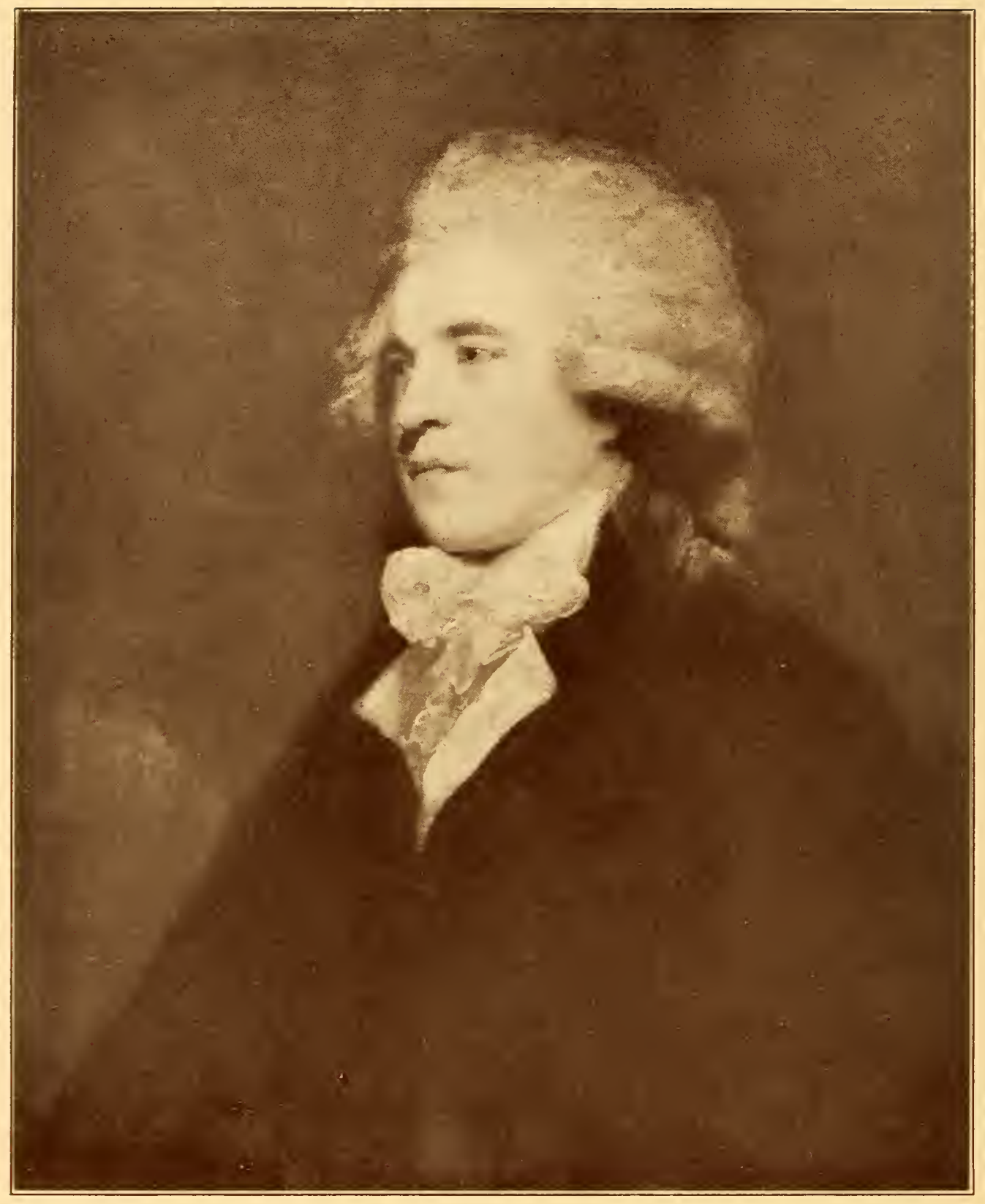


SIR JOSHUA REYNOLDS, P.R.A.

( I723-I792)

SIR GEORGE HOWLAND BEAUMONT

Canvas, 25 inches by 30 inches

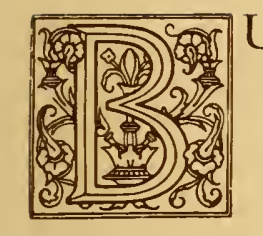

UST, face almost in profile, looking to the right, wears a black coat with white scarf around the neck and powdered wig.

Sir George Howland Beaumont (I750-1827), connoisseur, patron of art and landscape painter, was the son of Sir George Beaumont, the sixth Baronet, and Rachel, daughter of Michael Rowland of Stonehall, Dunmow, Essex, where he was born November 6, I753. He succeeded to the title in I 762, and was educated at Eton and New College, Oxford. In I 778 he married Margaret Willes, daughter of John Willes of Astrop, and granddaughter of Lord Chief Justice Willes. In 1790 he entered Parliament, and was member for Beeralston till I 796. "His social position, wealth and cultivation secured for him a distinguished position as a ruler of taste, and to these qualifications he added much personal attraction, being tall and good-looking, with polished manners and gentle address. In I 800 he began to rebuild Coleorton Hall, where, according to the dedication of Wordsworth to the edition of his poems in I 8 I 5 , several of that poet's best pieces were composed. Sir George knew Dr. Johnson, and it was under his roof that Sir Walter Scott met Sir Humphry Davy, Samuel Rogers and Lord Byron, who satirised him in "The Blues.'" He encouraged Coleridge, and helped to secure his pension. $\mathrm{He}$ made a collection of works of art, displaying good judgment and taste, and was chiefly instrumental in the formation of the National Gallery, to which he presented two fine Rembrandts, four Claudes, a Rubens, and some others. He died Feb. 7 , I 827 , aged 74 years.

This portrait, painted in 1787 , was exhibited in the Royal Academy of 1788 , and many times since in other places. 


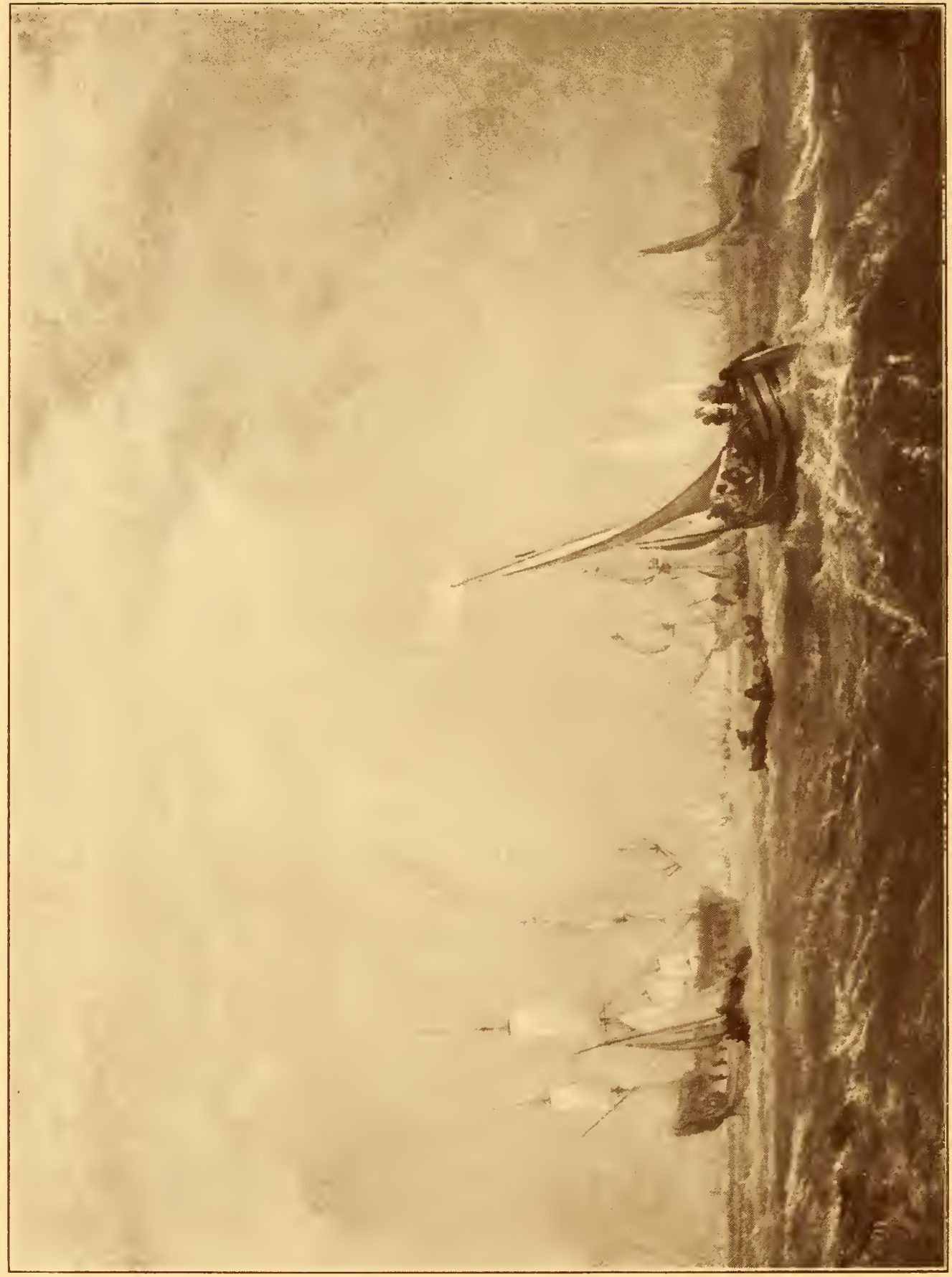


J. M. IV. TURNER

$\left(1775^{-1851)}\right.$

ANTWERP: VAN GOYEN LOOKING FOR A SUBJECT

Canvas, 481/4 inches by 36 inches

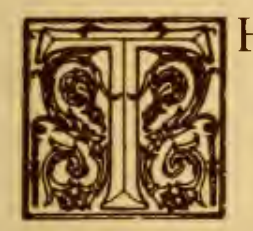

lection in Montreal.

Jan van Goyen was a landscape painter, born in Leyden in I596. His compositions generally represent rivers with boats and fishing barks, or peasants returning on the water from market, and in the background villages or small towns. Turner may have intended to honor van Goyen by joining his name to this picture, as he honored Ruisdael by calling after him three of his fishing scenes and by representing Canaletto in the foreground of his great Venetian picture, "The Bridge of Sighs."

The picture was purchased from the artist by E. Bicknell, of London, and remained in his gallery until 1863 , when it passed into the collection of J. Graham, of Glasgow, later into that of Guthrie, of London. It is mentioned in both Armstrong's and Wyllie's works on Turner, and illustrated in the book of the former opposite page ro8.

It was exhibited at the Royal Academy in 1833 , at the Boston Museum of Fine Arts in I 9 I 0 , and at the Old Master Exhibition (Knoedler), New York, 19r2. 


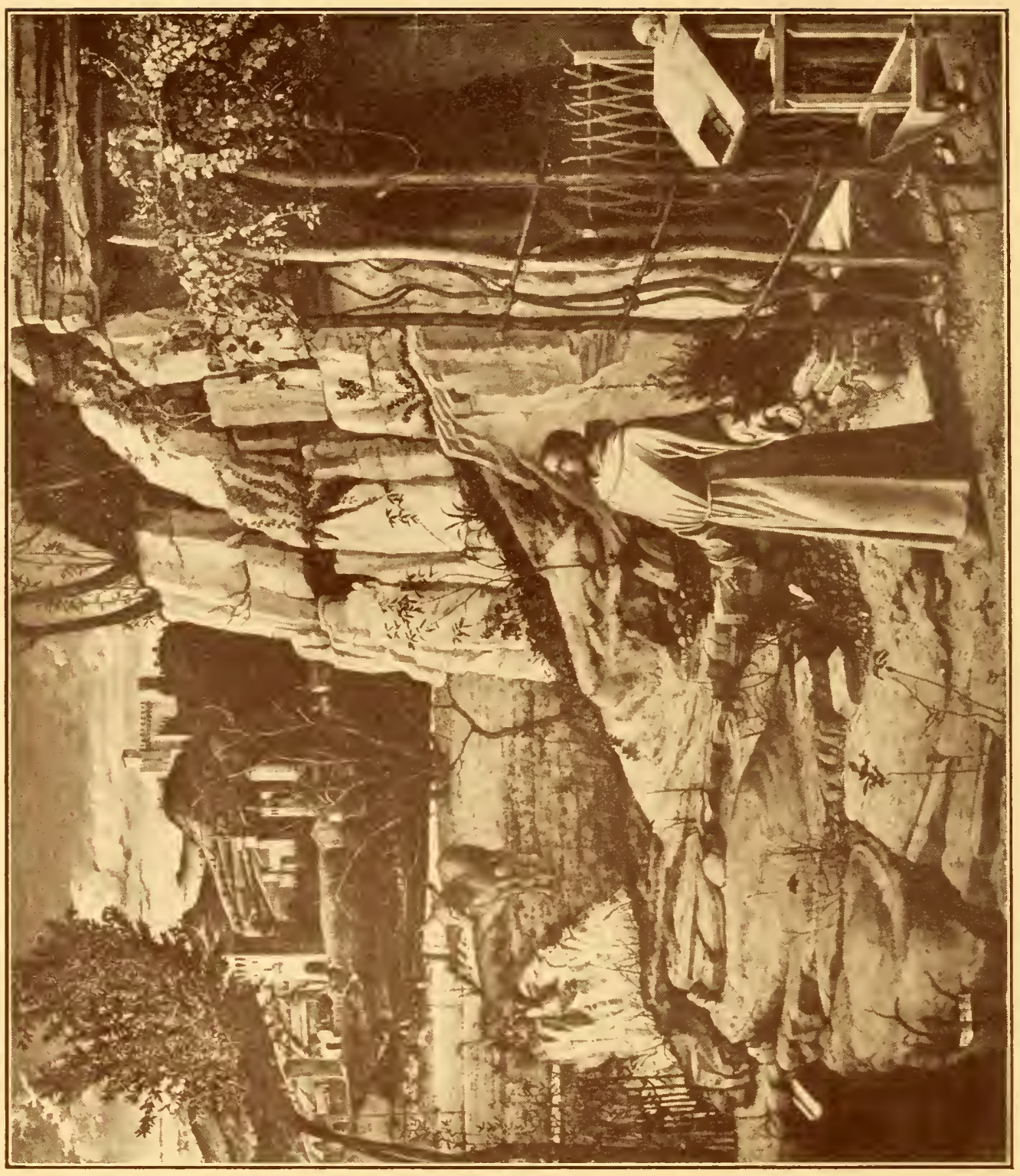




\section{GIOVANNI BELLINI}

\section{( I 430-3I-I 5I6)}

\section{ST. FRANCIS OF ASSISI}

\section{Panel, 54 inches by 49 inches}

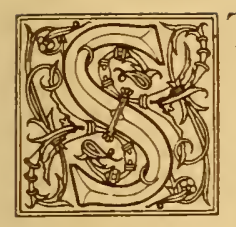

T. FRANCIS is standing near his hut, arms outspread, head thrown back, and gazing upward with raised eyes and open mouth. "Precipitous rocks of horizontal cleavage close the view to the right, and in a nook of them the saint has contrived himself a place of rest and prayer. A vine clambers up the slender poles of an open pergola, and beneath is his chair, with a back of plaited withes, his desk, his walking stick, his water crock, all painted with an intense and delighted minuteness, a combination of the austere with the dainty, both in invention and handling of which only that age held the secret. The rabbit peering from the rocks, the storks, the kingfisher, with every spray and trailer of vegetation, and the foliage of the single tree against the sky, all come out almost microscopically under study, with the general strong sense of mingled sternness and romance which breathes from the whole scene."-Sir Sidney Colvin.

The picture is first mentioned by the "Anonimo Veneziano," a I6th century writer, who saw it in the house of Messer Taddeo Contarini in I 525 , and said, "The oil picture, or panel, representing St. Francis in the Desert, is by Giovanni Bellini. It was commenced by him for Messer Giovanni Michiel, and has in the foreground a wonderfully elaborate and highly finished landscape."

In 1853 the painting was the subject of discussion before the Royal Commission on the National Gallery, and the authorities were censured for not acquiring for the British nation this "work of singular importance."

It was exhibited at Manchester in I 857 , at the Royal Academy in I9I2, and has been the subject of appreciative study and discussion by some of the great art critics of the day. 


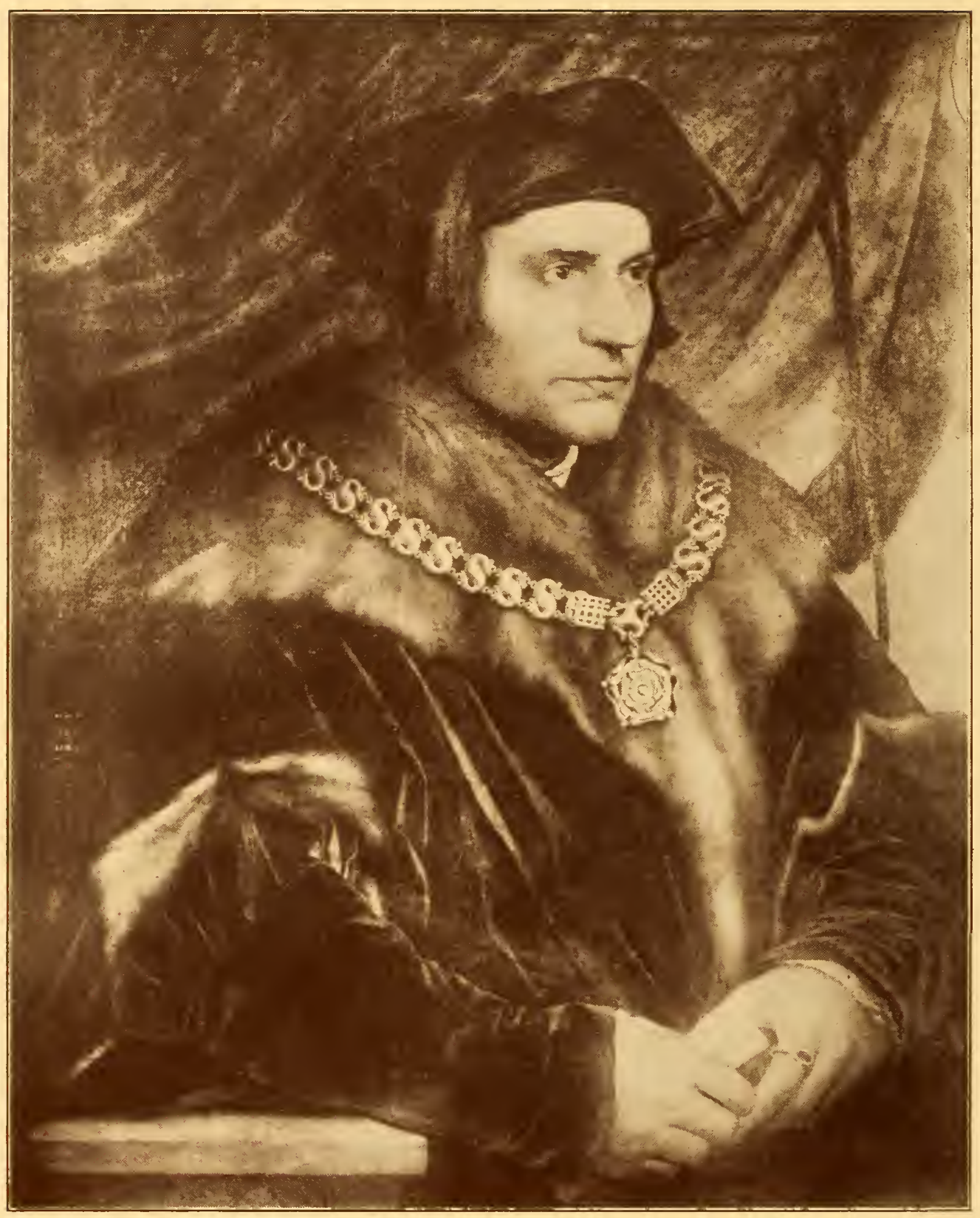




\section{HANS HOLBEIN}

The Younger

$$
\text { ( I 497-I 543) }
$$

\section{PORTRAIT OF SIR THOMAS MORE}

\section{Panel, 231/4 inches by 201/4 inches}

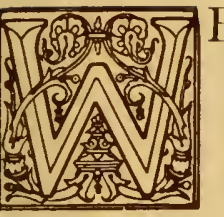

$\mathrm{E}$ see More before us in half-length figure, life-size, in a dark green upper coat, with fur collar and purple-coloured undersleeves; the hands resting in each other, the right hand holding a paper, while the arm is slightly leaning on a wooden table, on which the date is inscribed. He wears a heavy golden SS-chain, so-called because all the links have the form of a Latin $\mathrm{S}$; while a double rose in remembrance of the union of the Two Roses of York and Lancaster, is fastened to it-an ornament which only knights might wear. . . His face shows that calm repose which indicates the utmost harmony of nature and inward peace; but the expression is one of the deepest seriousness, though gentleness is linked with it. The finely-cut lips are firmly closed; there is something almost visionary in the bright and penetrating glance, though otherwise the features betoken clear judgment, combined with noble moral strictness and nobility of feeling. In looking at the picture, the words occur to us with which Erasmus in another passage concisely sums up More's characteristics: 'He possesses that beautiful ease of mind, or, still better, that piety and prudence with which he joyfully adapts himself to everything that comes, as though it were the best that could come.' . . . This repose, purity and gentleness he retained to the last moment when he mounted the scaffold."-Quoted from Dr. Alfred Woltmann.

There is a tradition that this portrait was thrown out of a window by Anne Boleyn, whose marriage to Henry VIII. was opposed by More, then Lord Chancellor. It was this opposition that was the indirect cause of his trial and execution. Many references to the portrait are made in the literature of art and it has been extensively reproduced. 


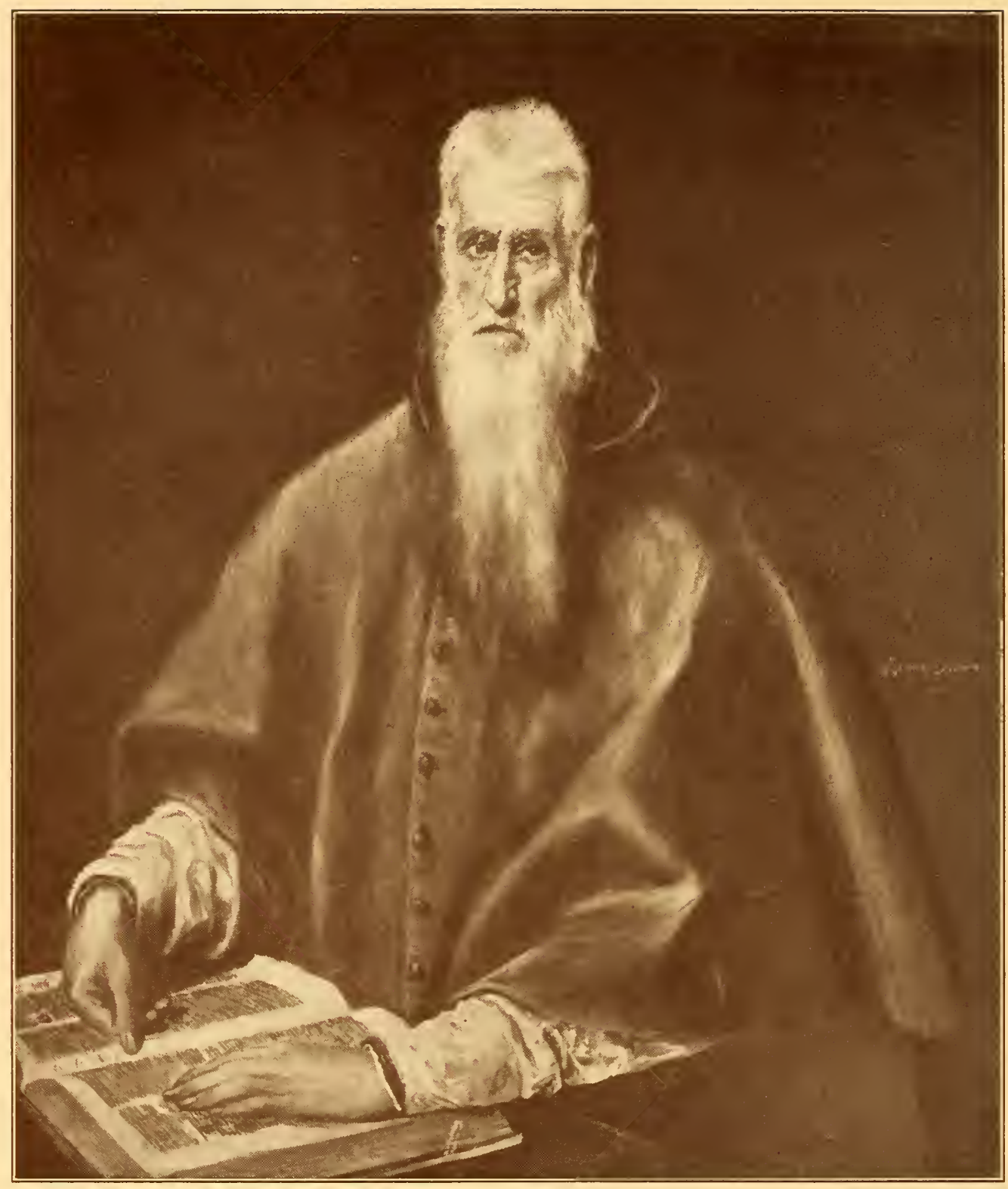




\section{"EL GRECO"}

(Dominico Theotocopuli)

\section{(I545?-I6I4?) \\ PORTRAIT OF A CARDINAL \\ (ALSO KNOWN AS SAINT JEROME)}

Canvas, 37 $1 / 2$ inches by $431 / 4$ inches

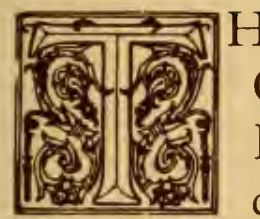

HERE are replicas of this picture in the National Gallery and the Prado, where it is called St. Paul. But the title is of small account. The picture is clearly the portrait of some dignitary of the church, or at least of the type of ecclesiastics of the day. The stubby hair and the long beard are approaching white, the face is greyed over, and silvery lights relieve the rose colored mantle. The head, in proportion to the body, is small but of extra length and narrowness, and the hands are extremely elongated. But by these exaggerations what expression of character is obtained! The head is at once that of a soldier, a scholar and an ascetic. The eyes have a cold, piercing directness; the long nose is indicative of relentless purpose and the mouth of iron rigidity and cruelty. One hand lies on the book with a gesture of refinement, almost of tenderness, while the thumb of the other is turned down with a decision that brooks no reasoning or opposition. In fine, the type is a strange mixture of intellectuality and bigotry; of elevation and narrowness, of gentleness and remorselessness. It might be that of an inquisitor, who condemns with no more hesitation than a surgeon, compelled by his diagnosis to use the knife.-Quoted from Caffin.

The picture was discovered, covered with grime, in a dark corner of the sacristy of the cathedral at Valladolid, Spain, where it had evidently hung undisturbed for centuries. M. Jules Cambon tried to buy it for the Louvre, but failed through the shrewdness of a Paris dealer, who also coveted it. From him it passed through various other hands until it reached New York. 


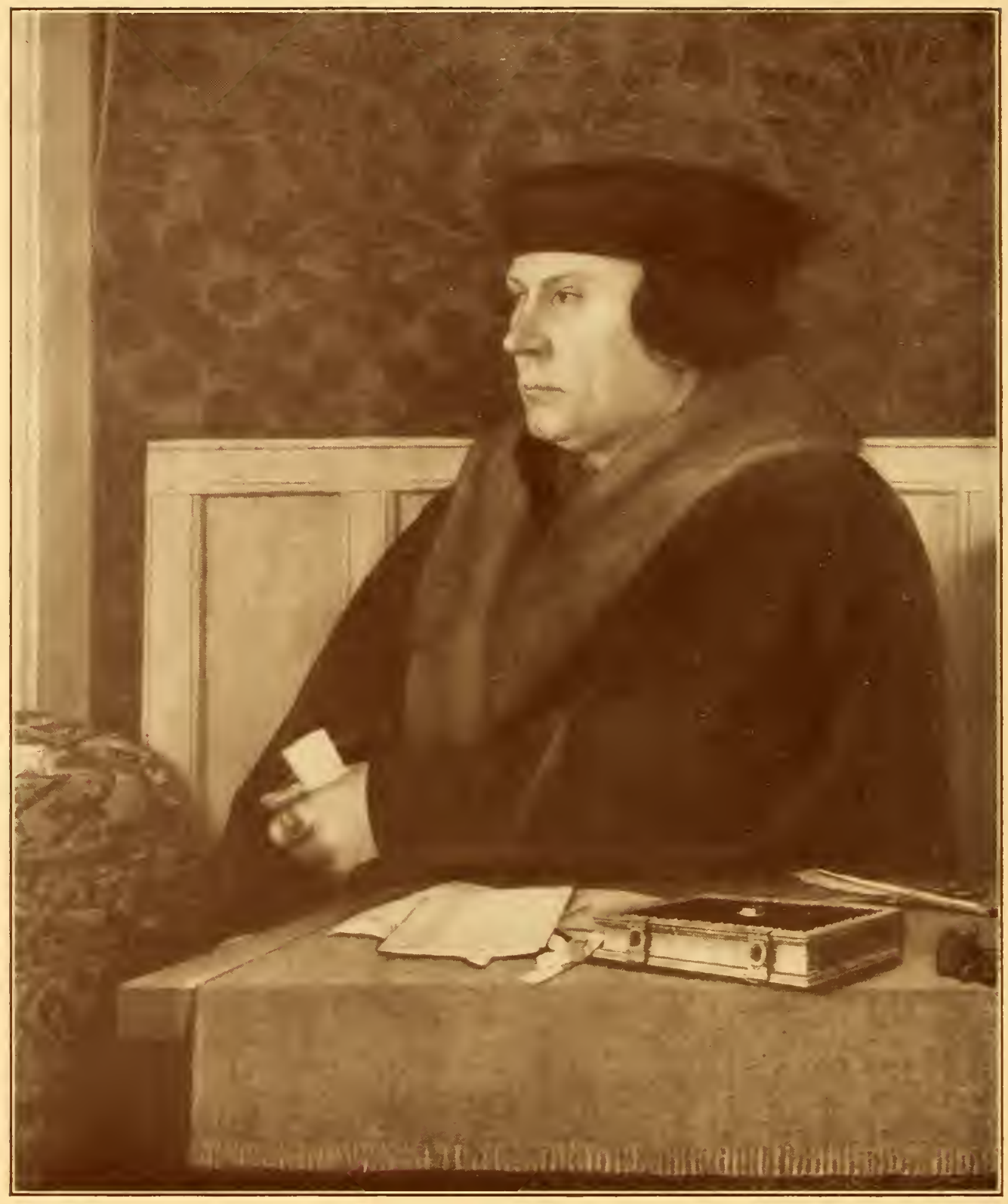




\section{HANS HOLBEIN}

The Younger

( I 497-I 543)

PORTRAIT OF SIR THOMAS CROMWELL

Panel, $24 \frac{1}{2}$ inches by 30 inches

TI ALF-LENGTH, seated to the left in a high-backed wooden seat, three-quarter face, looking toward a window, with a small table beneath it covered with a Turkish cloth, on which papers are placed. $\mathrm{He}$ is dressed in black surcoat with deep fur collar; black cap on bushy hair which almost covers his ears and falls on the back of his neck. Clean-shaven face; holds a paper in his left hand, on the first finger of which is a heavy signet ring. On the table are pen and ink, a richly-bound book with jeweled clasps, and several papers, on one of which is inscribed: "To our trusty and right well-beloued Thomas Cromwell Maister of our Jewel-house." On a second paper the word "Counseilor" can be deciphered. A Latin eulogy on a scroll was added after Cromwell's death, but later removed.

Henry VIII. sent his councillors to the block with the same indifference as he beheaded his wives; and Cromwell, the plebeian antithesis of the aristocratic More, came to the same fateful end at the Tower of London. Shakespeare makes Cardinal Wolsey charge Cromwell "to Hing away ambition; by this fell the angels." And by this fell Thomas Cromwell, who began life as the son of a farrier and died as Earl of Essex. While Sir Thomas More lost his head because he opposed the king's marriage to Anne Boleyn, Cromwell met the same fate through his encouragement of Henry's love for the new queen and the resentment of the Catholic nobles which this and cognate acts engendered.

This historic portrait descends from Sir Thomas Pope, one of Cromwell's instruments in the suppression of the monasteries; thence through the collections of Lord Douglas, the Countess of Caledon, and the Earl of Caledon. 


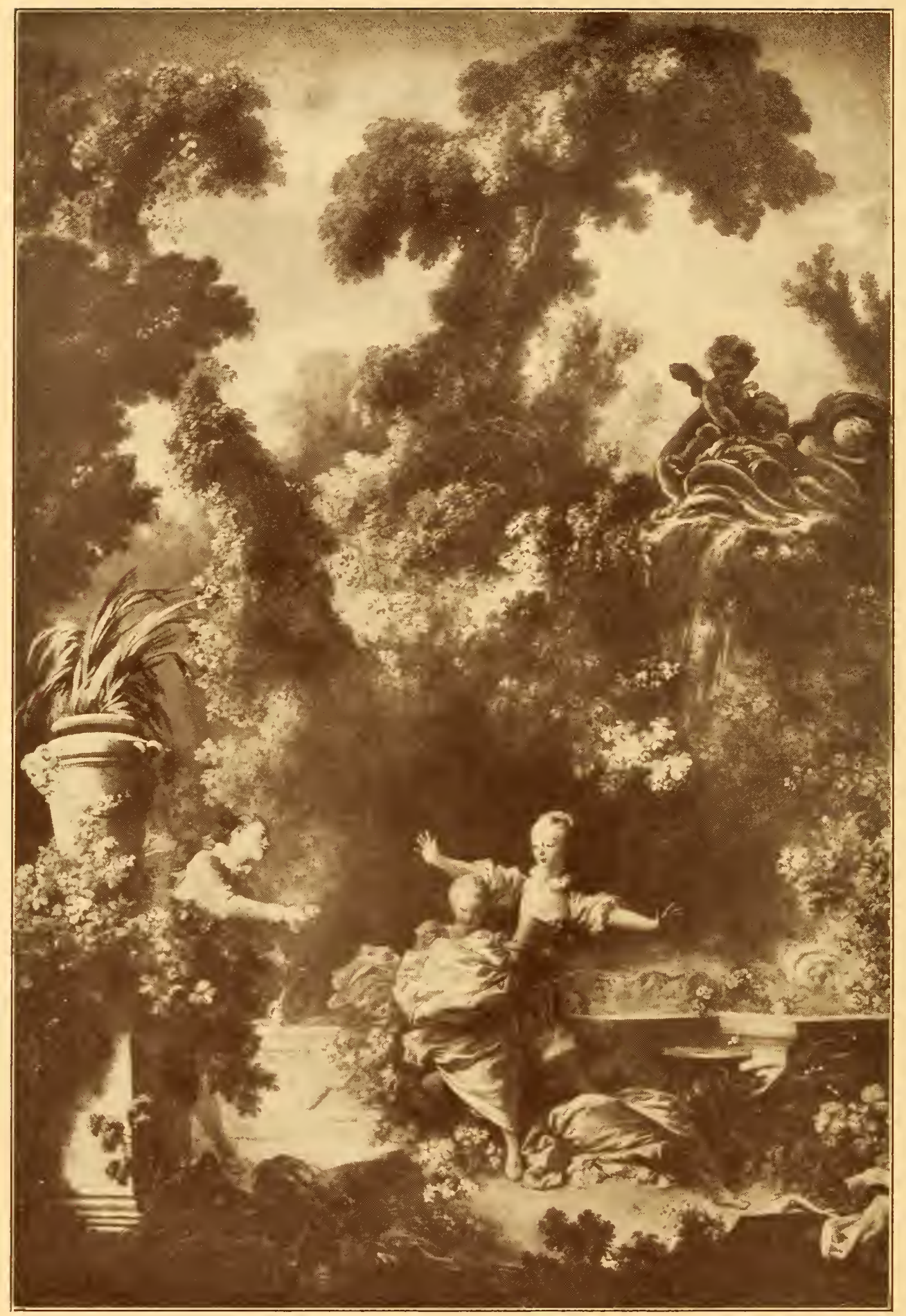




\section{JEAN-HONORÉ FRAGONARD}

\section{( I732-1806)}

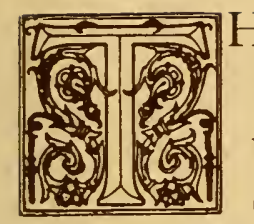

HE Romance of Love and Youth is the title which has been given to the set of decorative panels which were begun in 1772 for the Pavilion of Louvedu Barry. In one of the rare letters left by Fragonard, dated March 29th, I 773, reference is made to these paintings, as occupying him to the exclusion of other work ordered by the King.

They were never put in place in the pavilion for which they were designed; the reason alleged being that Mme. du Barry, displeased with the subject of the panel entitled L'Abandon, declined to receive them, and they were thrown on the artist's hands. Fragonard kept them in his studio for twenty years, when, in I 793, he fled from the horrors and dangers of the Revolution to the shelter of his friend Maubert, at Grasse, in Southern France, taking the panels with him. He returned to Paris after the Terror, and died there neglected and almost forgotten, in I 806. The panels were left at Grasse; and they remained there practically unknown until $\mathrm{I} 898$, when they were sold at auction by M. Malvilain, the grandson of $\mathrm{M}$. Maubert. Messrs. Agnew were their purchasers; and in the autumn of the same year they were exhibited in London, where the late Mr. J. P. Morgan bought them. They were afterwards removed to the Metropolitan Museum, New York, and exhibited there in a room specially designed for them. On Mr. Morgan's death the panels came into the present ownership. 


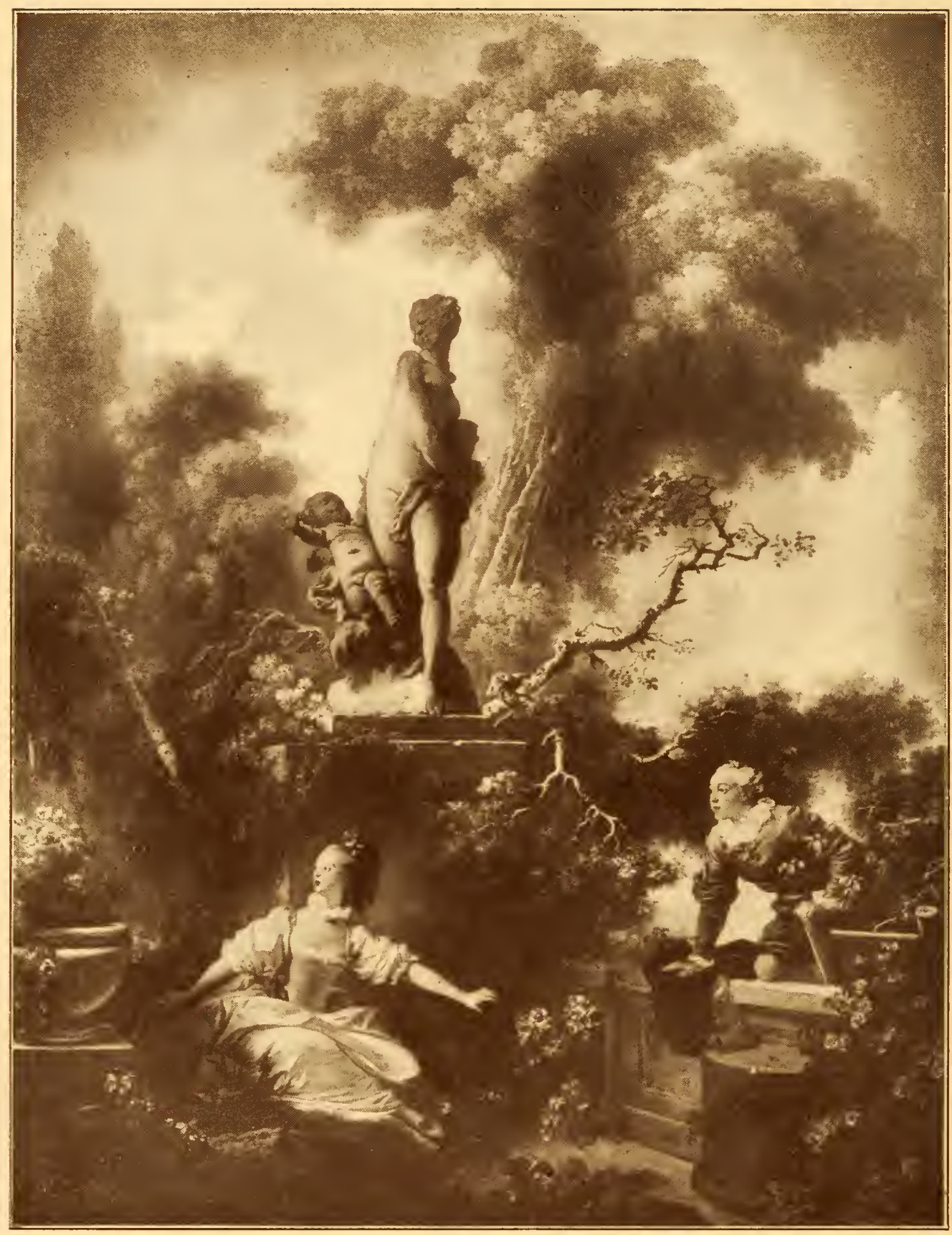


The five principal pictures are as follows:

1. The Pursuit (La Poursuite). The heroine, with outstretched arms, runs away from her admirer, who offers her a rose. Her companions try to hold her.

2. The Meeting (Le Rendezvous). The heroine sits on the grass by a statue. Her lover climbs the wall by means of a ladder. She looks over her shoulder as though fearing she might be seen. Fragonard has given the pair the features of Mme. du Barry and her royal gallant, though much rejuvenated in both cases.

3. Memories (Les Souvenirs). The heroine sits on a stone pedestal in a park, looking over old letters. Her lover stands by her, his arm around her waist.

4. The Lover Crowned (L'Amant Couronné). The couple pose for a painter. The lover sits at his mistress's feet, and she holds over his head a crown of flowers. Portalis says in his book on Fragonard, published in 1889: "This canvas is pictorically the splendid climax of all that has gone before. It shows the official triumph of love following upon the more intimate, the truer triumph that has preceded it. The colors in the paintings which open the series have, for all their exquisiteness, been tempered by a certain moderation. Here they burst forth in full splendor, in full passion, making together a bold and ringing harmony breathing forth a very pæan of victory."

5. The Abandonment (L'Abandon). This, the final scene of the series, takes place in a garden in autumn. The heroine is seated alone at the foot of a column surmounted by a sun-dial fashioned as a Cupid sitting on the world.

In addition, there are nine minor designs, meant as subsidiary to the general theme, which complete the unity of the scheme of decoration. 


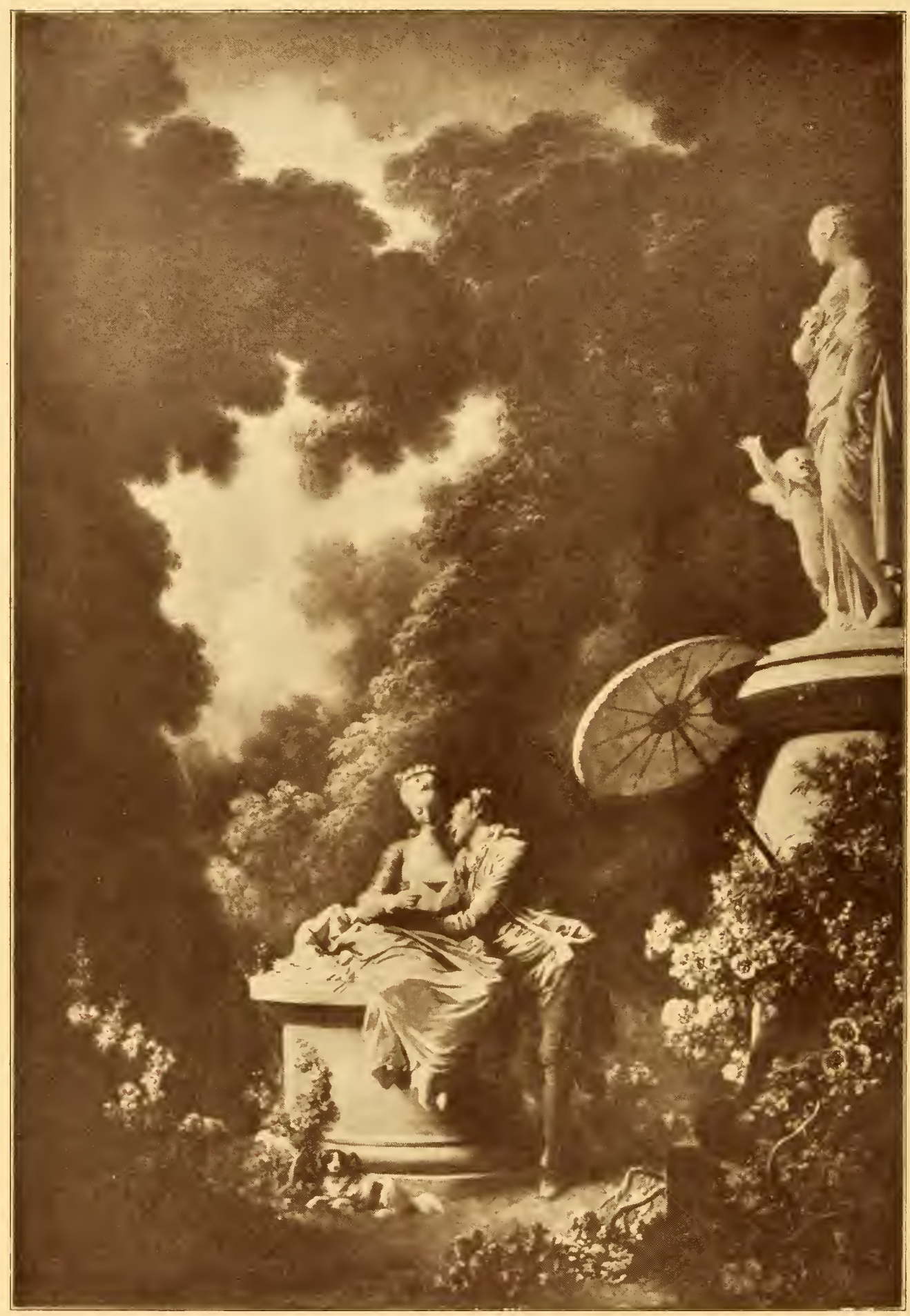


"Whether Fragonard painted for a future or for his contemporaries matters little, since we of a generation to him unknown may revel in his creative and radiant joy. 'To see Fragonard at his best, one must now come to America,' said one art critic; to see him at any time is an exquisite delight and an invitation to revel in the delicacy of color which cannot be equalled. The firmness of line shown in his drawing is so enwrapped and developed in the charm of coloring, combined with a daintiness of touch, that make the spectator fairly tremble with delight. From a painter of the Gallic race, one would look for effects of beauty which probably 'never were on sea or land,' but even among French types of genius, have we ever seen but one Fragonard. Inconceivably fertile in imagination, unless given a specific order for Gods and Goddesses of mythology, he secured his subjects from the every-day incidents around him. Taking these merely as a theme for his brilliant fancy, he translated them into such forms of beauty, such loveliness of dainty hues, that fairyland itself must have been open to his enchanted gaze. Watteau is pale and colorless beside these ravishing tones of the primary colors. Let us trust there never will be a Fragonard craze, that no modern copyists will feel inspired to imitate that wonderful vivacity, that charm of the combination of vivid imagination married to a hand absolutely sure of its technique, and fairly overpowered with the perceptive penetration to succeed in fixing an iris and to grasp a rainbow's glint."

The foregoing extract from a private letter recently received is so full of charm and so daintily appreciative as to call for its inclusion here. 


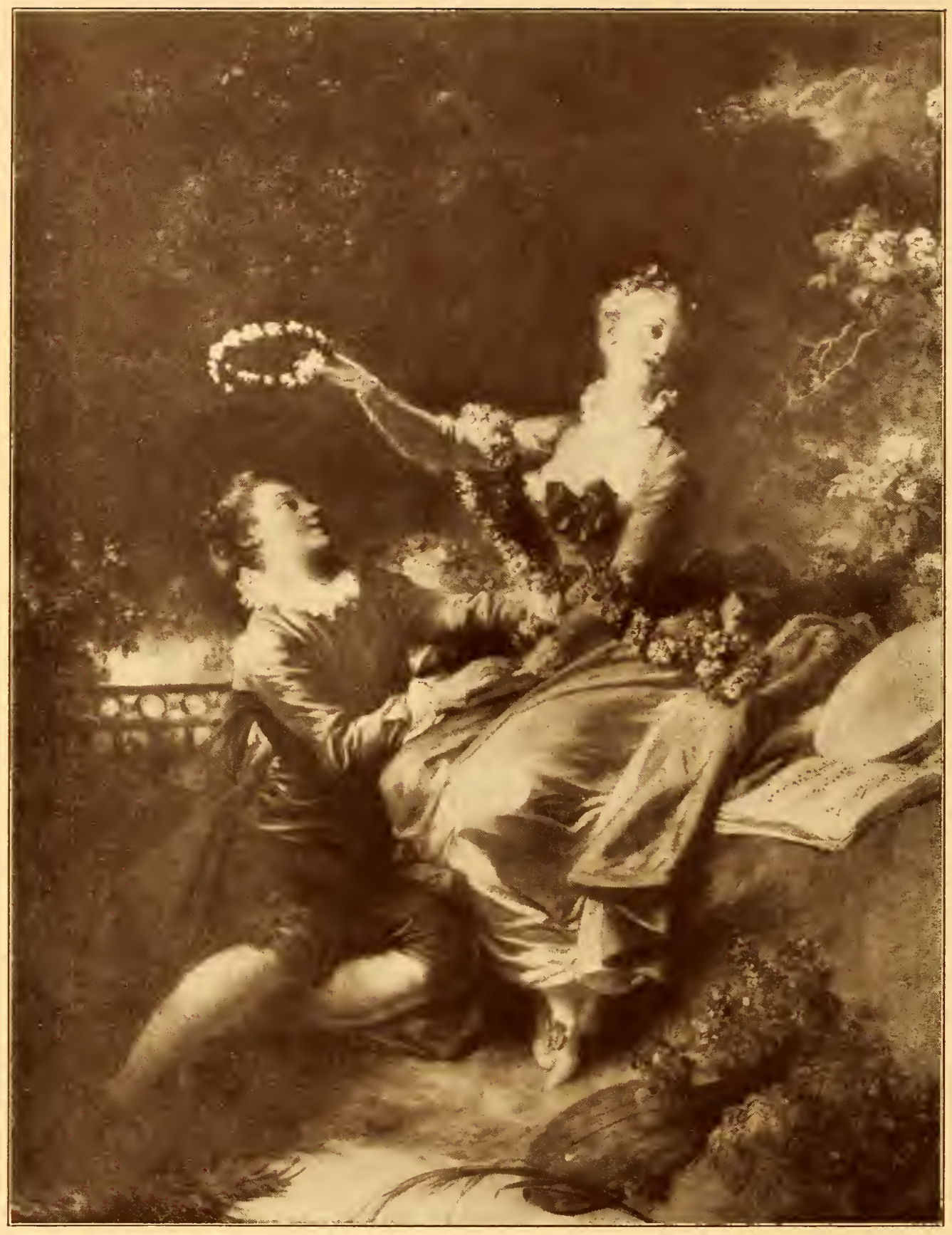




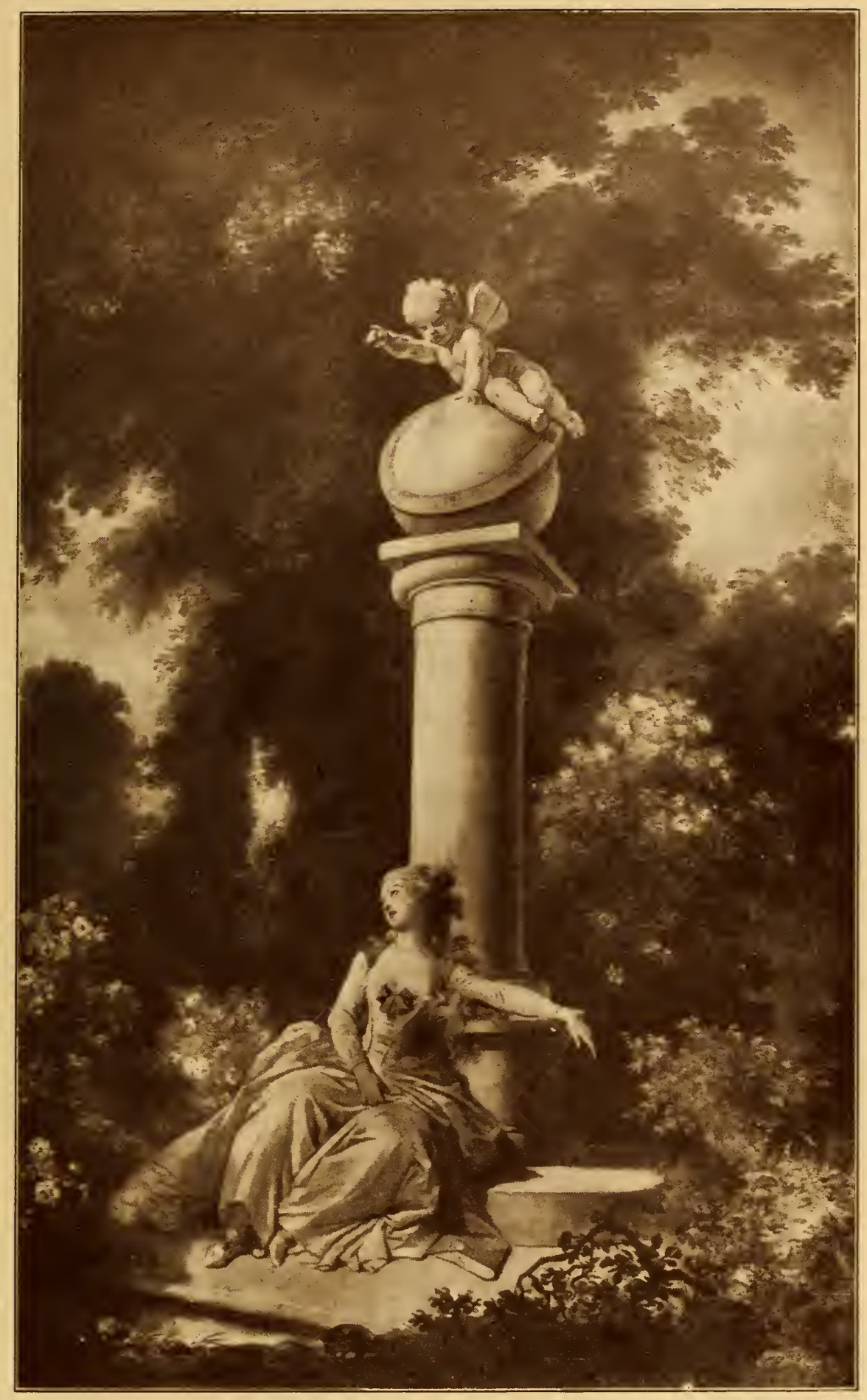




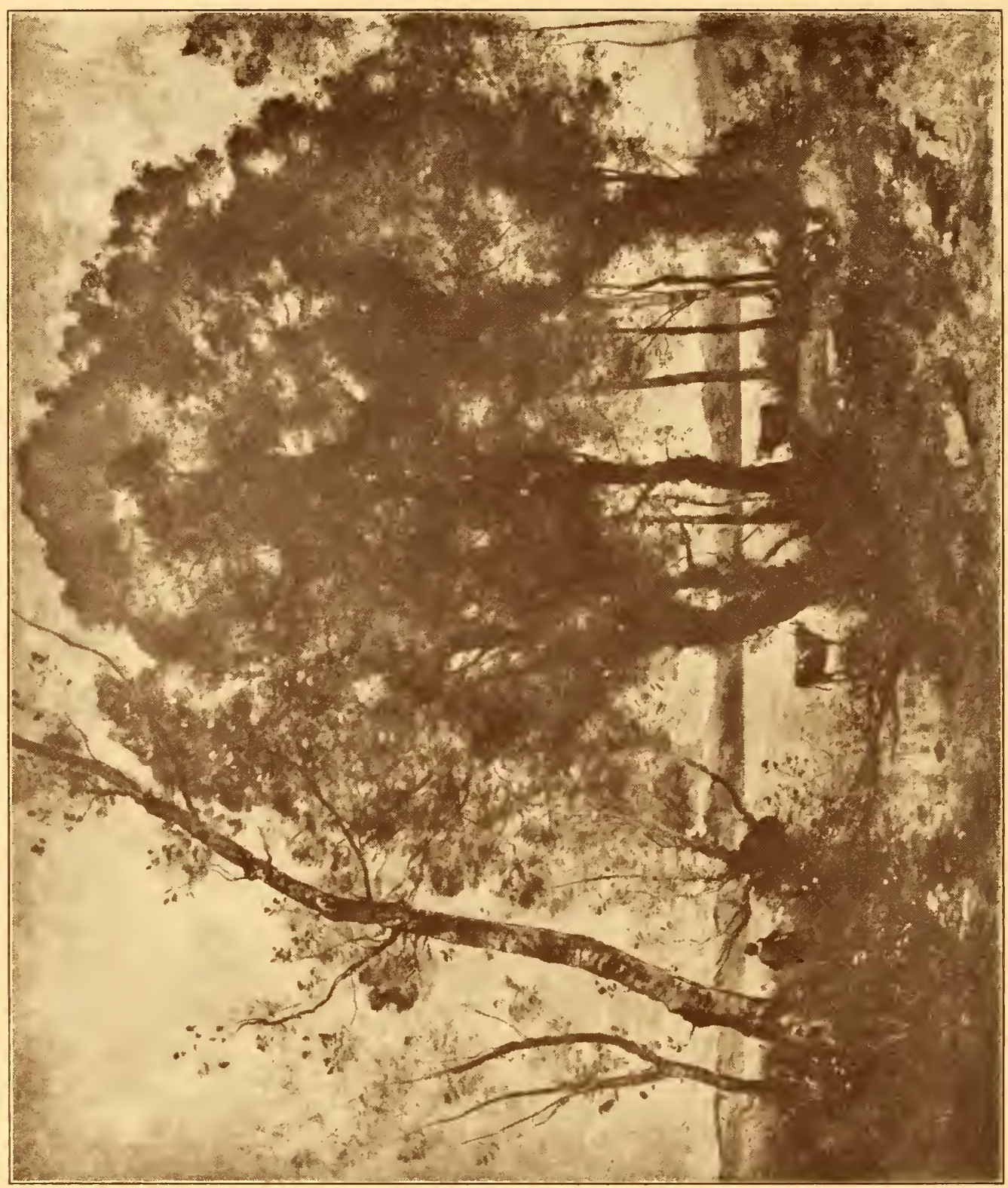




\section{J. B. C. COROT \\ ( I $796-1875)$ \\ LE LAC}

Canvas, 62 inches by 52 inches

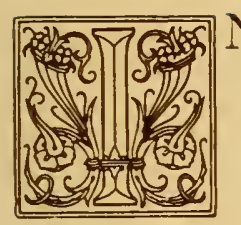

$\mathrm{N}$ the centre of the picture, by the water's edge, rises a cluster of trees, brown in tone. Standing a little way in the water is a brown cow; other cows are seen among the trees to the right, and a man is observed on the low bank to the left. Away beyond stretches the broad lake to a line of low distant hills, along which a bright light travels. The scene in its powerful rendering of nature vibrates throughout with the most sensitive lights and tenderly opposing shadows.

The picture, which was painted in $\mathrm{I} 86 \mathrm{I}$, is signed twice at the lower left "Corot." It has been etched by T. N. Chauvel and also by Felix Bracquemond. It was No. 696 in the Paris Salon of I86r, and again exhibited at the École des Beaux Arts in 1875, at the Séconde Exposition de Cent Chefs d'Euvre, Paris, in 1892 , and was hung in the place of honor at the Paris Exposition du Centénaire de Corot in I895. It was seen at the Guildhall, London, in I90I, at the Glasgow International Exhibition in I9IO, and at the Boston Museum of Fine Arts in the same year. It has been many times reproduced, and in Thomson's work on the Barbizon School of Painters it is mentioned as "the most important of all Corot's works." It has been in the de Bériot, Gavet, Brun and Fraissinet de Bellanger collections in Paris, and in that of Alexander Young, Esq., of London. 


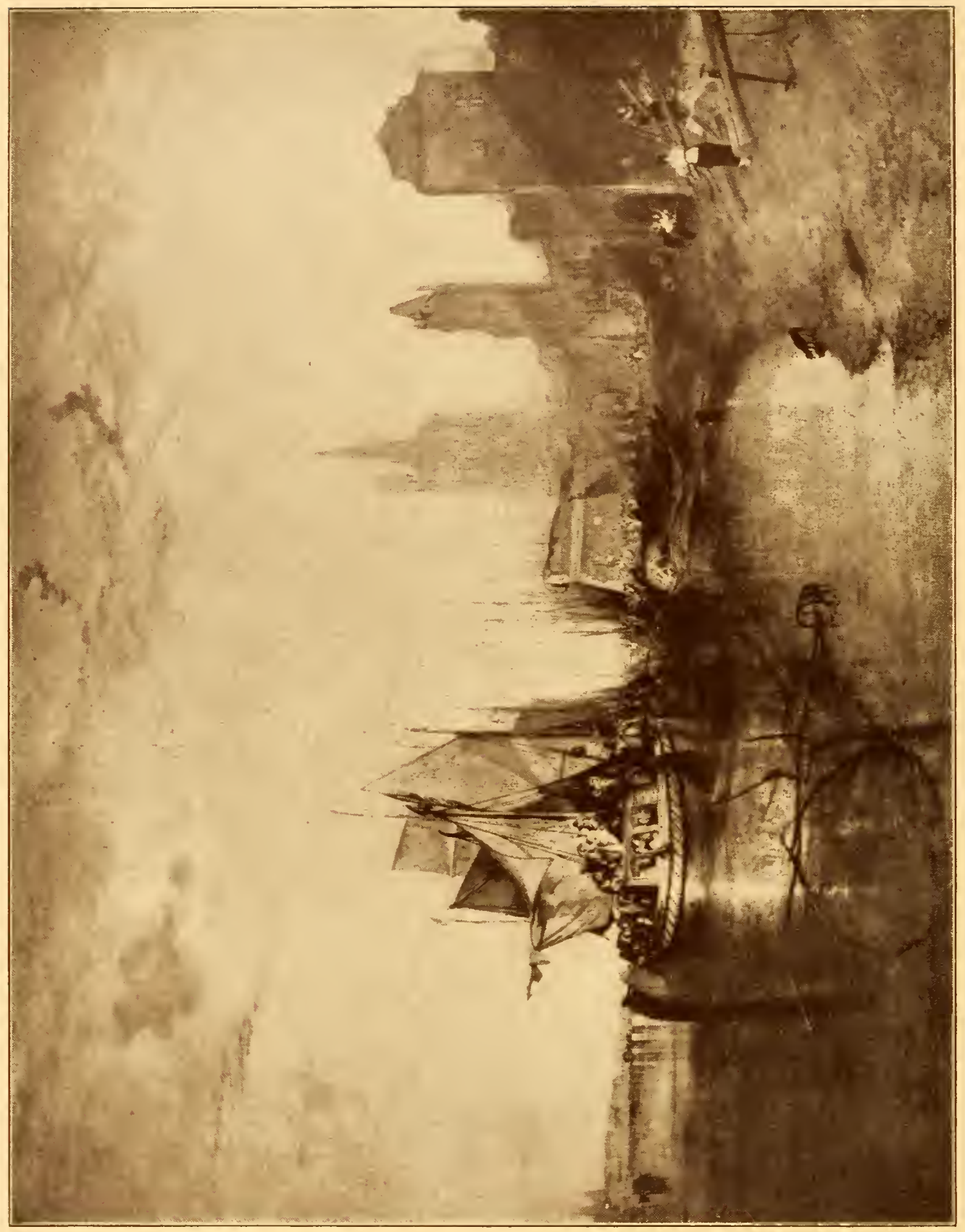




\section{J. M. W. TURNER \\ $\left(1775^{-1} 85 \mathrm{I}\right)$}

COLOGNE: ARRIVAL OF A PACKET BOAT, EVENING Canvas, $881 / 2$ inches by 60 inches

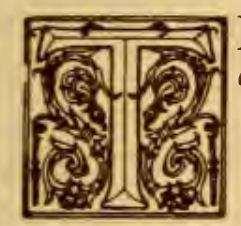

HE Rhine, under the walls of Cologne, with the 'Treckschuyt' arriving and taking up its berth for landing the passengers. The river is placid, and as she makes her way past the picturesque craft beside her. On the right are the walls, with a tower and spire breaking their line, and running up to a postern, backed by a taller tower. In the foreground, some balks of timber, and the spiderlike arms of a couple of those fishing-nets which tourists by the Rhine and Moselle know so well, reflected in the wet sand, and casting their evening shadows as well as their reflections. In the distance you catch a glimpse of the distant bridge of boats. The sky is being rapt through that rosy change which precedes the dying of twilight into dark. The sun is not seen in the picture, but a cloud lies between it and the spectator; and from behind this the broad-slanting rays strike on town and tower, and shoot down to the stream flinging on its unruffled face and on the rounded sides of the 'Treckschuyt' the shadows of intercepting edifices, while from the lighted water a glow strikes back into the cool violet shadows cast by wall and steeple, and fills them with reflected light."-Quoted by Philip Gilbert Hamerton.

This is the famous picture which Turner, at the Royal Academy in I 826 , daubed with lamp-black so that its brilliant coloring should not dim two paintings by Lawrence which hung beside it. The incident is mentioned by Ruskin, Wyllie, Hamerton, Lucas, and other writers on British art. 


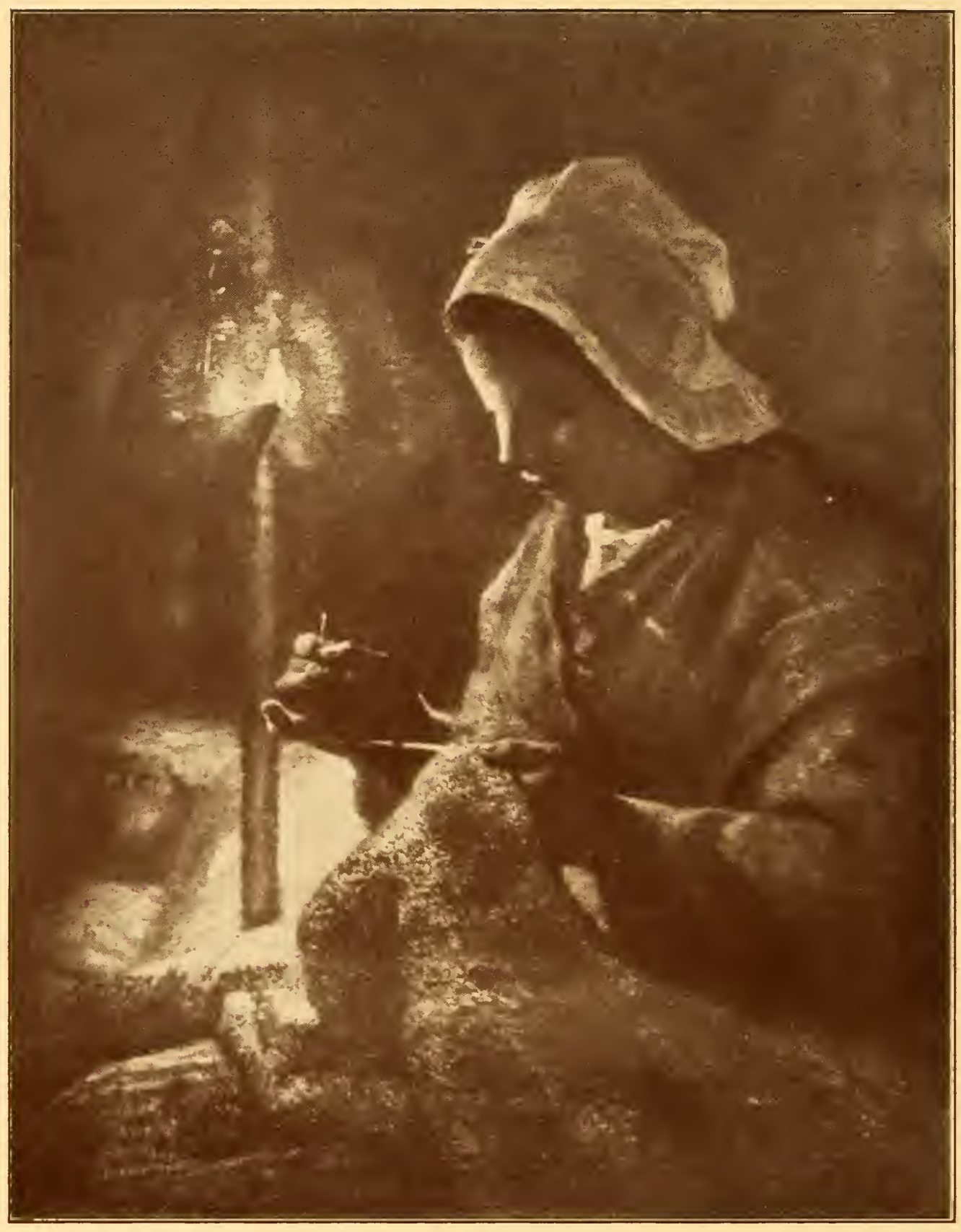




\section{JEAN FRANÇOIS MILLET}

\section{( $1814-1875$ ) \\ LA FEMME À LA LAMPE}

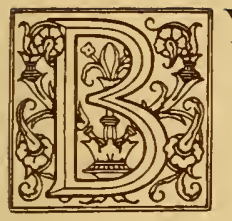

$Y$ the flickering light of a primitive lamp suspended from a horizontal bar a young woman, seated, sews on a sheepskin coat. Her costume is that of a peasant of la Hague (Northern France), country of the painter. She wears a white cap on her inclined head, a pink scarf over her shoulders, and a thick woollen dress of faded blue. Near her, to the left of the picture, sleeps a child. On the right, part of a spinning wheel is seen.

Illustrated and described in Vol. I., part 8, of "Masters in Art," where it is stated that this picture was painted in 1872 . This painting is also mentioned in Sensier's Life of Millet. Exhibited at the Boston Museum of Fine Arts, I9 Io.

"There is contentment in every line of the face of this Woman Sewing by Lamplight. It is the face of a happy young wife and mother. She sits close by her baby's bedside that she may listen to his gentle breathing as he sleeps, and she smiles softly to herself while she sews. It is a sweet face which bends over the work, and it is framed in the daintiest of white caps edged with a wide ruffle, which is turned back over the hair above the forehead, that it may not shade her eyes. The garment that lies on her lap is of some coarse heavy material. No dainty bit of fancy work is this, but a plain piece of mending. . . . The light gilds the mother's gentle profile with shining radiance; it illumines the fingers of her right hand, and gleams on the coarse garment in her lap, transforming it into a cloth of gold. The baby, meanwhile, lies on the other side of the lamp in the shadow. His little mouth is open, and he is fast asleep. We can almost fancy that the mother croons a lullaby as she sews."-Jean François Millet, by E. M. Hurll. 


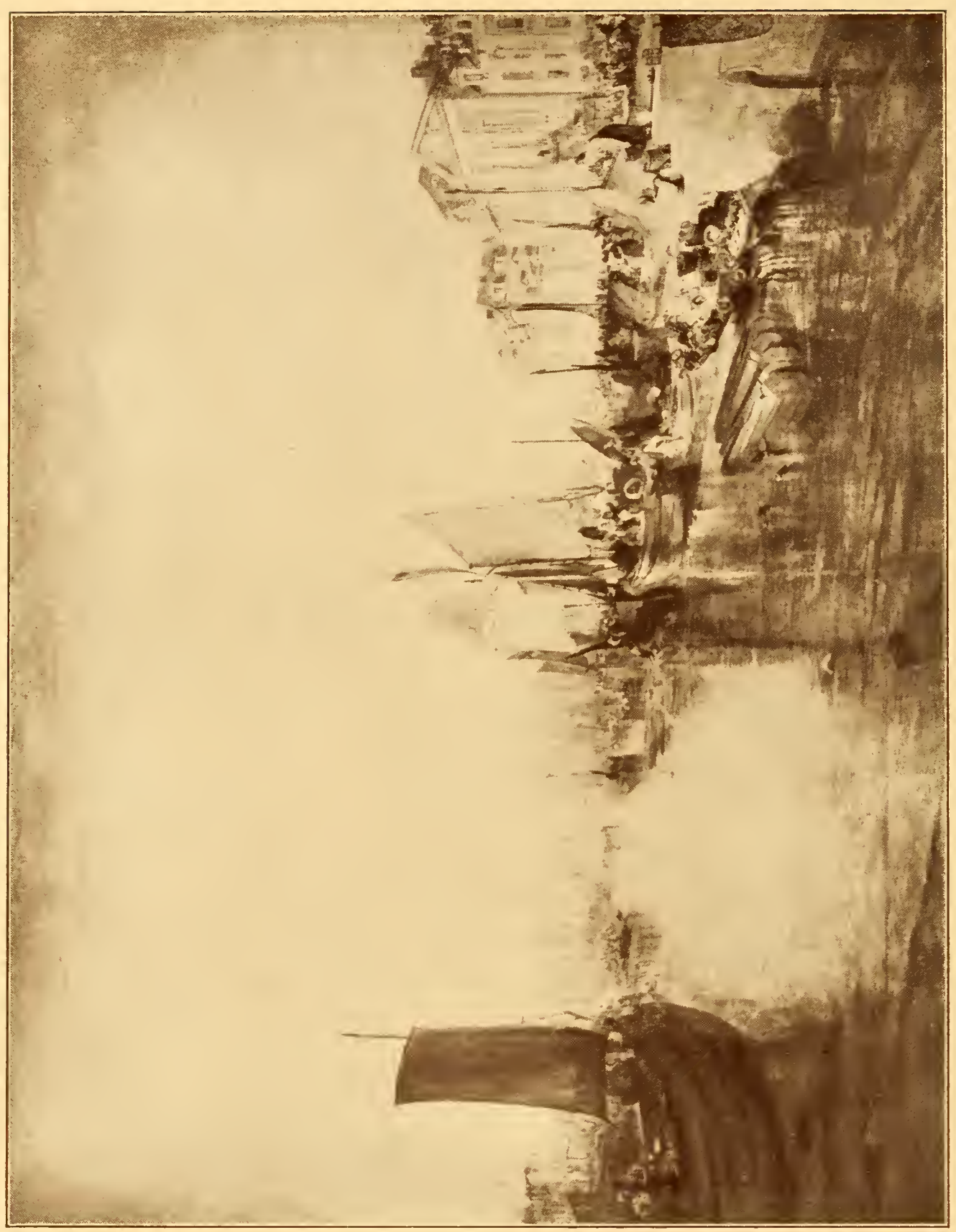




\section{J. M. W. TURNER}

$$
\text { ( } 1775-185 \mathrm{I})
$$

\section{THE HARBOR OF DIEPPE}

Canz'as, 883/4 inches by 681/2 inches

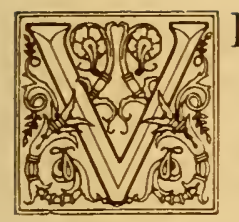

IEW looking toward the town; the harbor is thronged with boats, on which are numerous figures; a market is being held on the quay on the right; blue sky, with clouds. Warm evening light.

Dated on the logs to the right: i 826 .

Mentioned in Armstrong's "Turner," London, I902, p. 22 I. " " Thornbury's "Life of Turner," II., 400-3.

Exhibited at Royal Academy, London, I 825, No. I 52.

" “ Messrs. Agnew's, London, I903.

" " Royal Academy, London, i9 Io, No. II 2.

Collection of James Wadmore, i 854.

" "John Naylor, Esq., Leighton Hall.

This painting, as well as its famous companion, "Cologne," appears to have passed directly from Turner into the collection of James Wadmore, which comprised many important canvases by Turner, Wilkie, and others, and a few old masters. Mr. Wadmore died at his residence in Upper Clapton, in 1853 , and his pictures, numbering I 86 , were sold the following year. The Gentleman's Magazine of contemporary date makes special mention of the sale of the "Cologne" and the "Dieppe" paintings. They were bought by Mr. John Naylor, J.P., Lord of the Manor of Leighton, Welshpool, and remained in his collection until his death in 1906 . Bryan lists them as being in the possession of Mrs. Naylor after this date. 


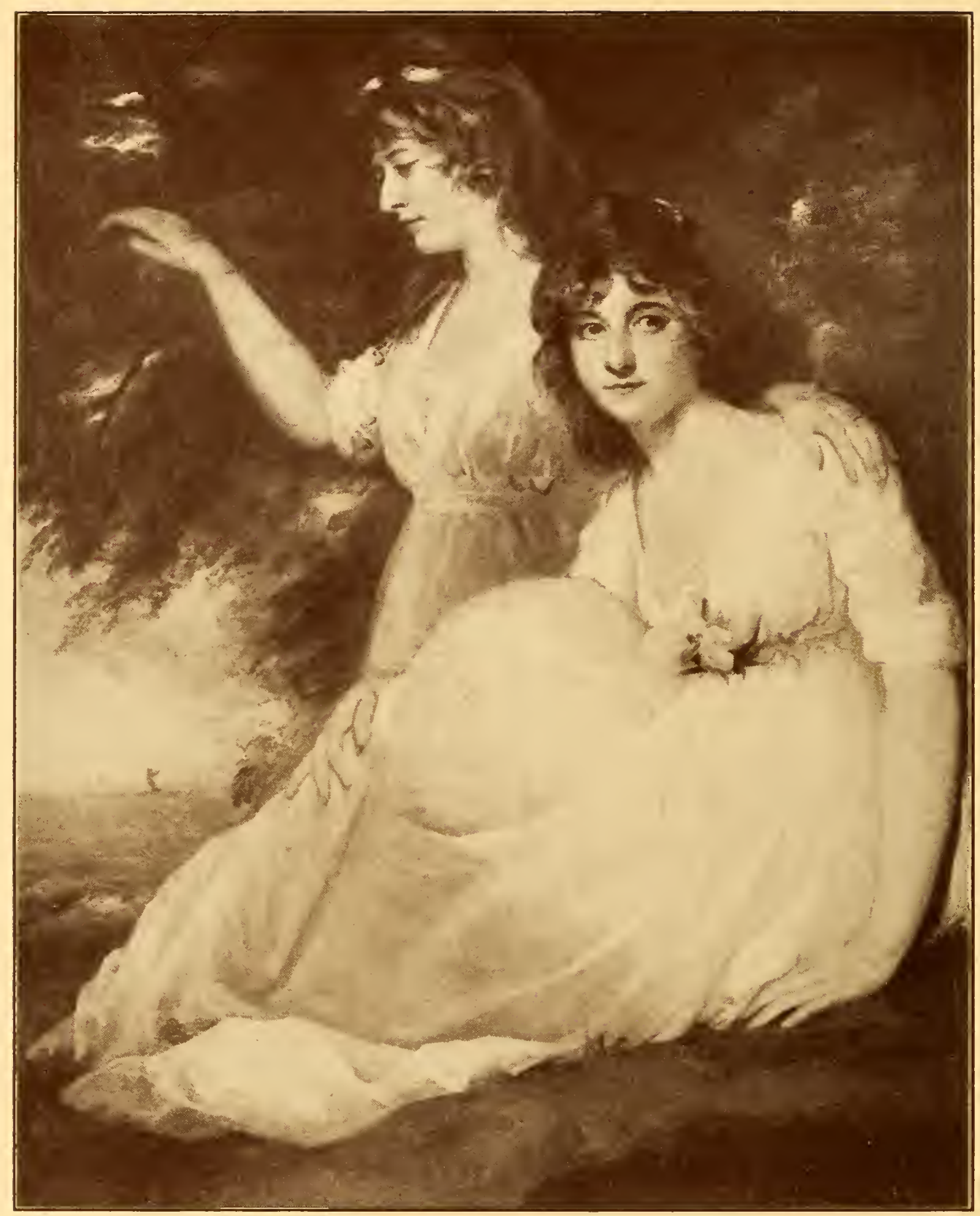




\section{JOHN HOPPNER, R.A.}

\section{( $7758-1810)$ \\ THE LADIES SARAH AND CATHERINE BLIGH}

\section{Canzas, 40 inches by 50 inches}

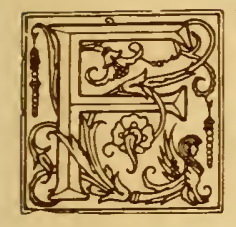

ULL length figures of two young girls, one kneeling, profile looking to the spectator's left; the other seated, looking full face out of the picture; both in white dresses, open at the throat, with short slèeves; background of foliage with glimpse of the reach of the Thames at Gravesend, as seen from Cobham Park, seat of Lord Darnley.

Formerly owned by the Earl of Darnley.

These young ladies were the daughters of John, third Earl of Darnley. Sarah, born Feb. IO, I772, died unmarried; and Catherine, born May 6, I 774, married (Aug. 8, i 804) William Stewart, third Marquis of Londonderry. He was a couple of years younger than herself, and had already dis. tinguished himself both as a soldier and diplomat. He entered the army when only I 4 , and after being wounded in battle, was lieutenant-colonel of the Fifth Dragoons at 19. At 25 he was under-secretary for Ireland, and occupied this office at the time of his marriage to Lady Catherine Bligh. A year or two later he became under-secretary of war. He commanded the Hussar Brigade under Sir John Moore in r 808, and was adjutant-general to Wellington the following year with the rank of major-general. He greatly distinguished himself during the Peninsula campaign, and was invalided home in I 8 I 2. This year his wife died, aged 38 , leaving a son, who became fourth Marquis.

Her husband, who lived till i 854 , and occupied many important diplomatic and ambassadorial positions, married again. His second wife was the daughter of Sir Henry Vane-Tempest, his bride being 22 years his junior; a disparity that prompted Tom Moore to lampoon Lord Londonderry in a weak rhyme. 


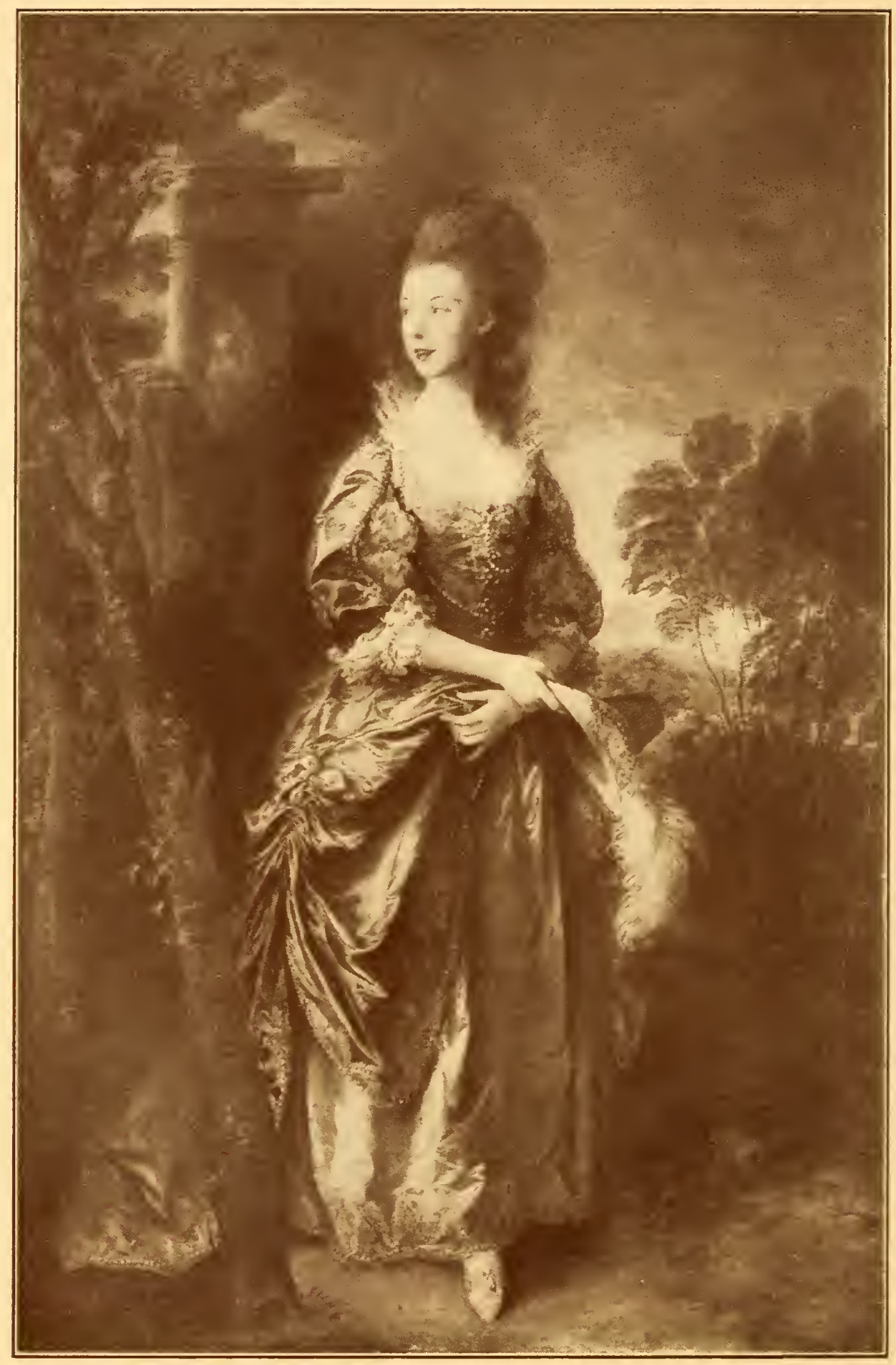




\section{THOMAS GAINSBOROUGH, R.A.}

\section{( I727-I787)}

\section{THE HON. FRANCES DUNCOMBE}

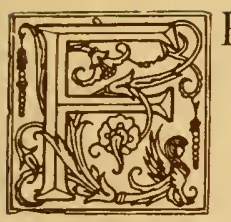

RANCES DUNCOMBE, daughter of Anthony Duncombe, Lord Feversham, Baron of Downton, Wilts. Born I 2 th Nov., I 757 ; married, I 778 , Woolwich. She died in 1827 without issue.

By his third wife (I758) Lord Feversham had another daughter, Anne, who on Jan. 24, r 774, married Jacob, second Earl of Radnor. This painting has at various times been wrongly described as the portrait of Anne Duncombe, Countess of Radnor.

Frances Duncombe is here represented walking in a park and stepping toward the spectator, with her face turned three-quarters to the right, and hands crossed in front of her; in the right hand she holds her hat, trimmed with pearls and white plumes, and her left hand is toying with a string of pearls. Her light auburn, slightly powdered hair, dressed with pearls, is brushed back from the high forehead, and curly locks undulate gracefully over the shoulders. Her dress consists of a long blue satin train bordered with pearl embroidery and draped at the sides, showing a full view of a white satin underskirt richly ornamented with pearls. The low-cut corsage is adorned with strings of pearls and fastened with a large ruby and pearl jewel; she wears an Elizabethan lace collar, lace ruffles to the short three-quarter puffed sleeves, and white satin shoes with pearl fastenings.

This painting, once owned by the Earl of Chesterfield and later by Baron Lionel Rothschild and Chas. J. Wertheimer, has had a romantic story which forms the subject of a chapter in IV. P. Frith's "Autobiography and Reminiscences." 


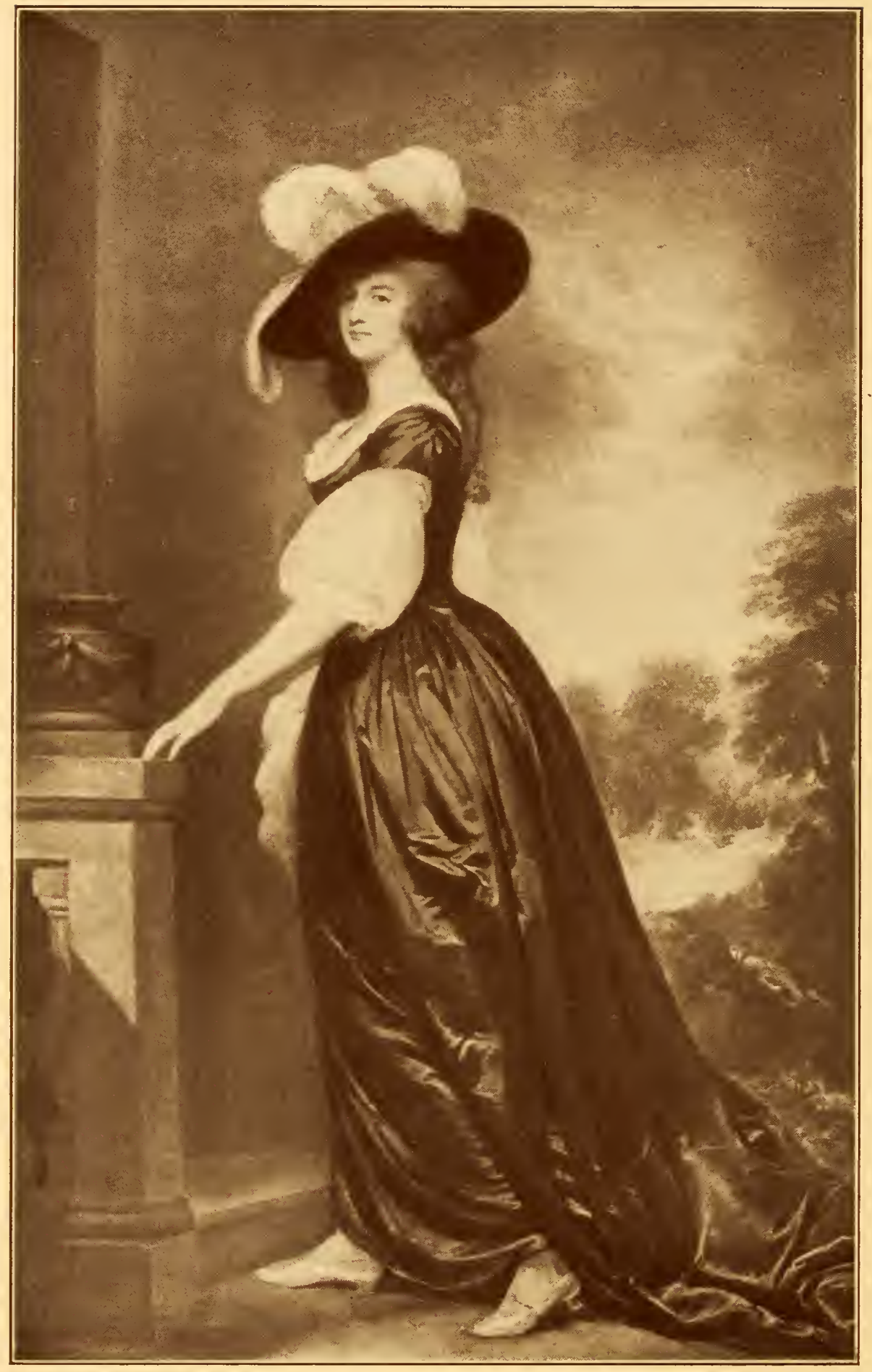




\section{( I734-I802) \\ LADY MILNES}

Canvas, 58 inches by 97 inches

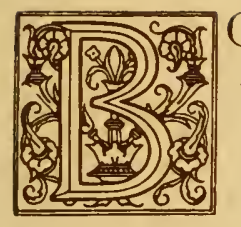

ORN in 1767 or 1768 , Charlotte Frances was the third daughter of John Albert Bentinck and granddaughter of William, first Earl of Portland. In I 785 she married Robert Shore Milnes, who later became Governor of Martinique and afterwards Governor of Lower Canada. He was not popular there, being described as "an easy, well-meaning man, with talents scarcely above mediocrity, of no self-confidence whatever, and consequently easily influenced by the irresponsibilities about him." He was created a Baronet in I80I, and died in I837. His widow, who had five children, survived him over twenty years, and died at the age of 82 , at Tunbridge Wells.

This portrait has been the subject of an interesting study by Mr. W. Roberts, the well-known critic, who says of it:

"Though somewhat conventional in treatment, there is in the face and attitude a subtlety and charm which place it above the average of Romney's whole-lengths. The graceful sweep of the plain brown satin dress, relieved by the white puff sleeves, and the coquettish pose of the large black hat adorned with waving plumes of white ostrich feathers, constitute a decorative ensemble of the highest order and attraction. A veritable Lady Clara Vere de Vere in rank, dignity, 'in glowing health and with boundless wealth,' yet in his magic art we feel that Mrs. Milnes was above and beyond all a really human woman."

The portrait was formerly in the collection of the Right Honorable the Earl of Crewe. It has been frequently exhibited and is mentioned in various books on Romney and his art. 


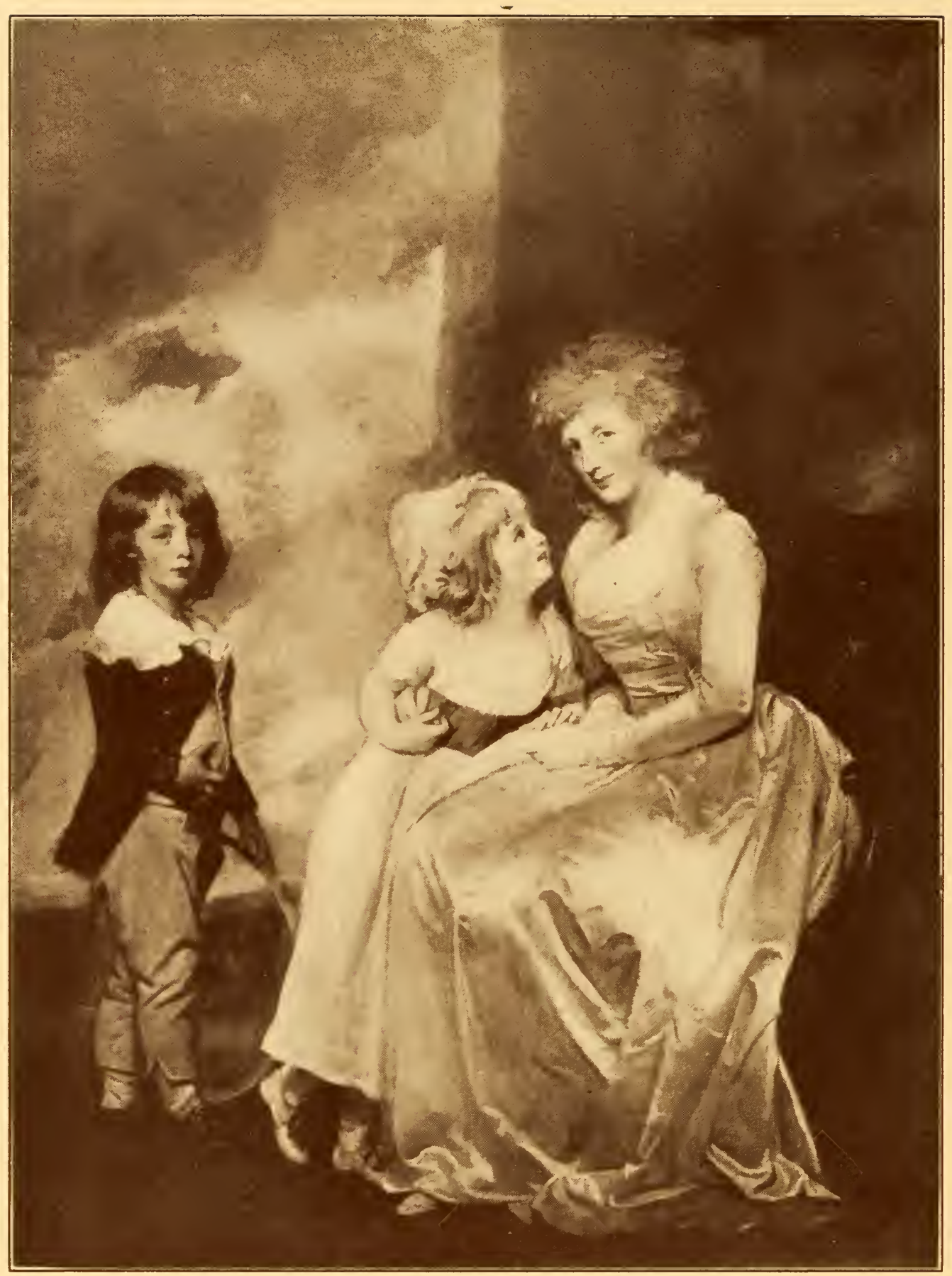




\section{GEORGE RONNEY}

( I 734-1802)

HENRIETTA, COUNTESS OF IVARIVICK,

AND HER TWO CHILDREN

Canvas, 60 inches by 78 inches

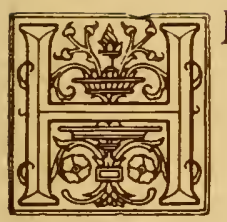

ENRIETTA VERNON, who eloped with George, second Earl of IVarwick, in I776, when she was sixteen and he a widower of thirty, was the eldest daughter of Richard Vernon, known in his day as the father of the turf and as "Jubilee Dickey." She and her sisters were noted beauties and were celebrated in verse by Horace Walpole. They were known as "The Three Graces," and in the literary gossip of their day frequent reference is made to them. Lady Warwick in particular is extolled for "her amiable sweetness and gentleness," and her life was one of serene unerentfulness. She bore her husband nine children, some of whom were distinguished.

Of the eldest son, who became third Earl of IVarwick, and who is the boy of this portrait, it was written of him after he attained manhood, that he had "evinced a predominant taste for chymistry," and that he invented and patented a soap for the navy "that will not curdle in salt water." He appears, however, to have been "extravagant and speculative," and to have so seriously impaired the family fortune that the latter part of his life "was spent in penury, mortification and wretchedness."

The little girl of the portrait was the Countess's third child, Elizabeth, who died in January, I $\$ 06$.

The Countess herself died in ${ }_{1} \&_{3} \&$, having survived her husband twenty-two years.

The painting, made in I 787 -I $78 S$, has been extensively reproduced, frequently described, and exhibited at the British Institute, South Kensington, Burlington House, the Grafton Gallery, and in Boston and New York. It was previously owned by the Earl of IVarwick, IVarwick Castle. 


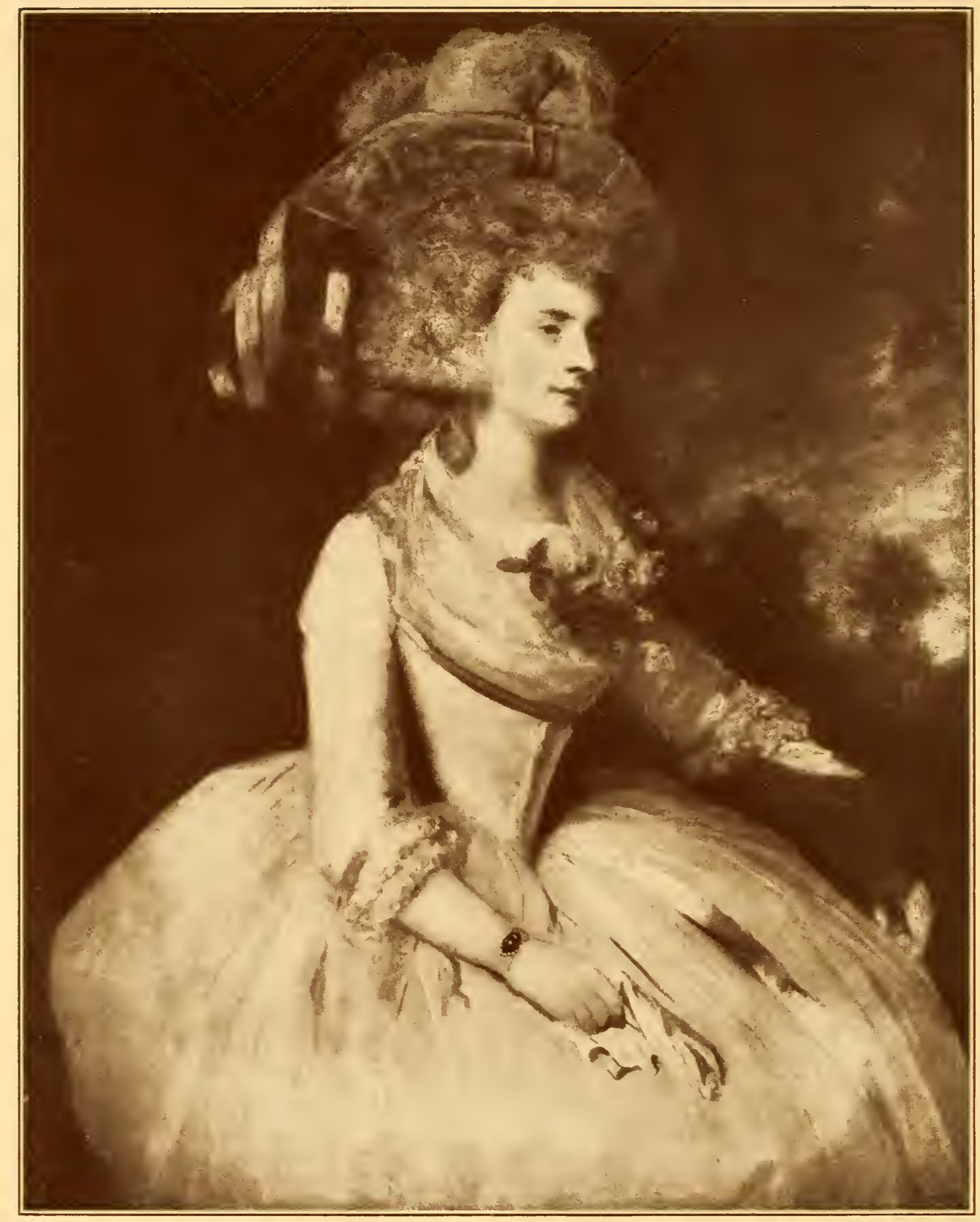


SIR JOSHUA REYNOLDS, P.R.A.

\section{(I723-I792) \\ LADY SKIPWITH}

Canvas, 40 inches by 50 inches

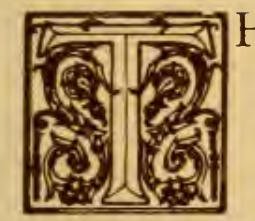

HREE-QUARTER length. Seated on a garden bench; head turned to the left, almost in profile; white muslin gown with blue ribbons; muslin fichu; at the breast a bunch of pink roses. On her powdered hair a white hat with ostrich feathers, and in her right hand she holds a white glove; foliage background; sky to left.

Eldest daughter of Hon. George Shirley and Mary, daughter of Humphrey Sturt of Horton and granddaughter of Robert, first Earl of Ferrers. She was also granddaughter of Humphrey Parsons, Lord-Mayor of London. She married Sir Thomas George Skipwith, Bart., on September 8, I 785 , and sat for this portrait a couple of years later, as noted in Leslie and Taylor's "Life and Times of Sir Joshua Reynolds," Vol. II., p. 512. She became a widow in July, I 790.

In 1864 the picture was at Tunbridge Wells, the property of Sir Peyton d'Estoteville Skipwith, Bart., who was then a minor of seven years and who died in I89I, when it became the property of his son, Sir Grey Humberton d'Estoteville Skipwith, Bart., eleventh and present baronet, from whom the picture comes.

It is mentioned in Armstrong's "Reynolds," p. 229, and illustrated in Vol. VII. of the engraved works of Sir Joshua Reynolds, published by H. Graves. It has also been engraved by G. H. Every in I 864 .

Exhibited at the Grosvenor Gallery, I889, No. I 4. " " " Old Master Exhibition, Knoedler \& Co.

The Skipwith name, originally spelt Schypwye, is derived from the town and lordship of Skipwith in Yorkshire, the family having been founded by Robert de Estouteville, Baron of Cottingham, in the time of the Conqueror. 


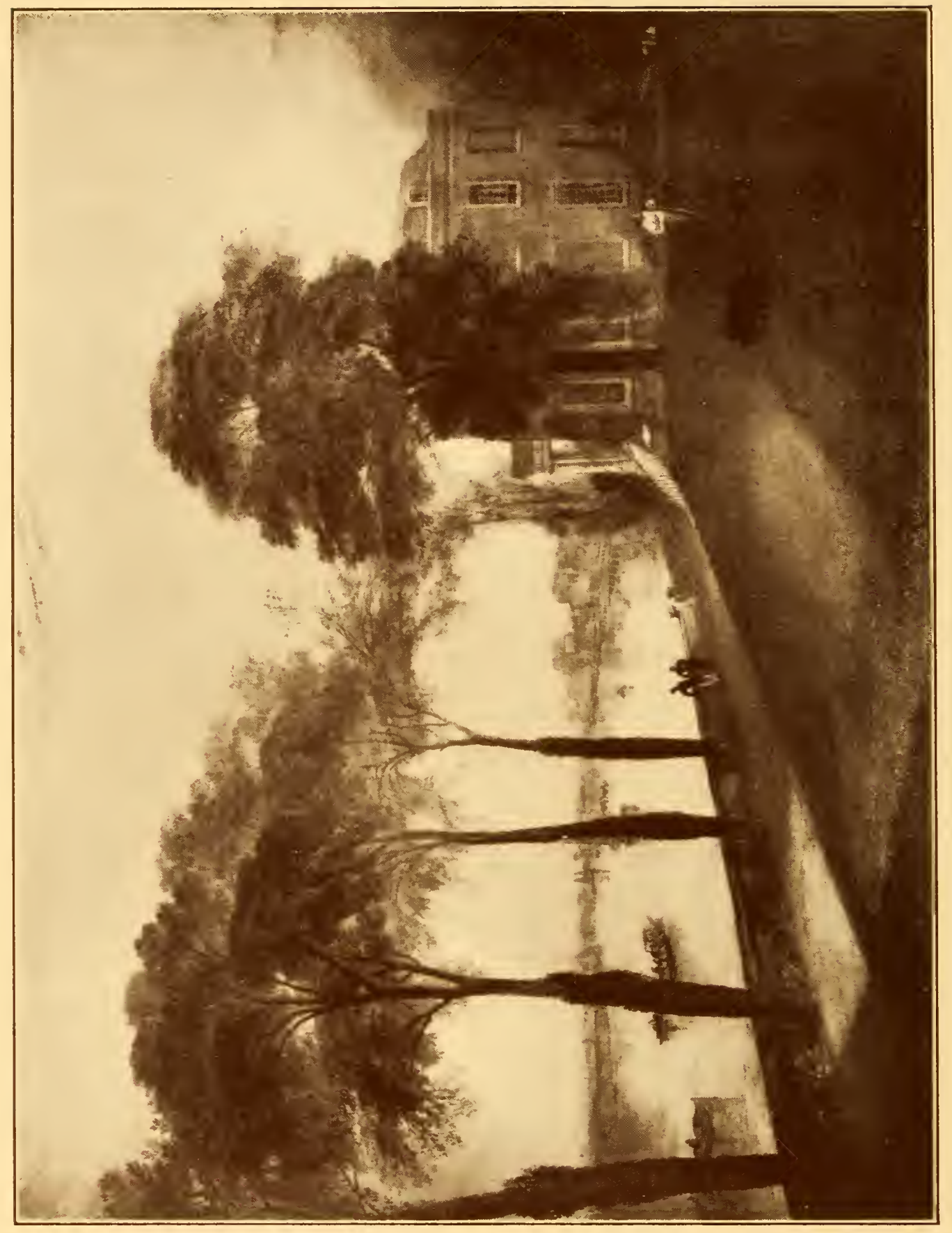




\section{J. M. W. TURNER, R.A. \\ $\left(\mathrm{I} 775^{-185} \mathrm{I}\right)$}

MORTLAKE TERRACE, EARLY SUMMER MORNING

(The Seat of William Moffatt, Esq.)

Canvas, $48 \mathrm{r} / 2$ inches by $36 \mathrm{~T} / 2$ inches

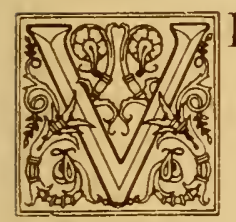

IEIV looking down the River Thames from the garden of a house which occupies the right of the picture; tree in front of the house; other trees on the terrace to the left. To the right of center a wheelbarrow, beyond a man with a scythe, and farther to right a boy with rake. To the left, against the low wall, two men standing.

The house is at present the offices of the Mortlake Urban District Council.

The painting, made in 1820 , is mentioned in Armstrong's work on Turner, pp. I 8 and I 9 , where is given the opinion of Bürger as follows: "This is one of the pictures I regard as a masterpiece, and which I should choose to convey to me the genius of Turner, absolutely without any influence of the Old Masters. Claude, the supreme 'illuminateur,' never did anything so prodigious."

Mentioned also in Armstrong's work on Turner, p. 225.

Exhibited at the Royal Academy, i 826.

" " " Burlington House, I 872 and I 895.

" " Guild Hall, I 899.

" " " " $"$ Boston Museum of Fine Arts, I9IO.

" " " Old Master's Exhibition, M. Knoedler \& Co., New York, I9I 2.

Collection of S. Mendel, Esq.

" " James Price, Esq.

" " Stephen G. Holland, Esq., London.

Turner painted this subject a second time, and astonished his critics by cutting a dog out of black paper and sticking it on his canvas. 


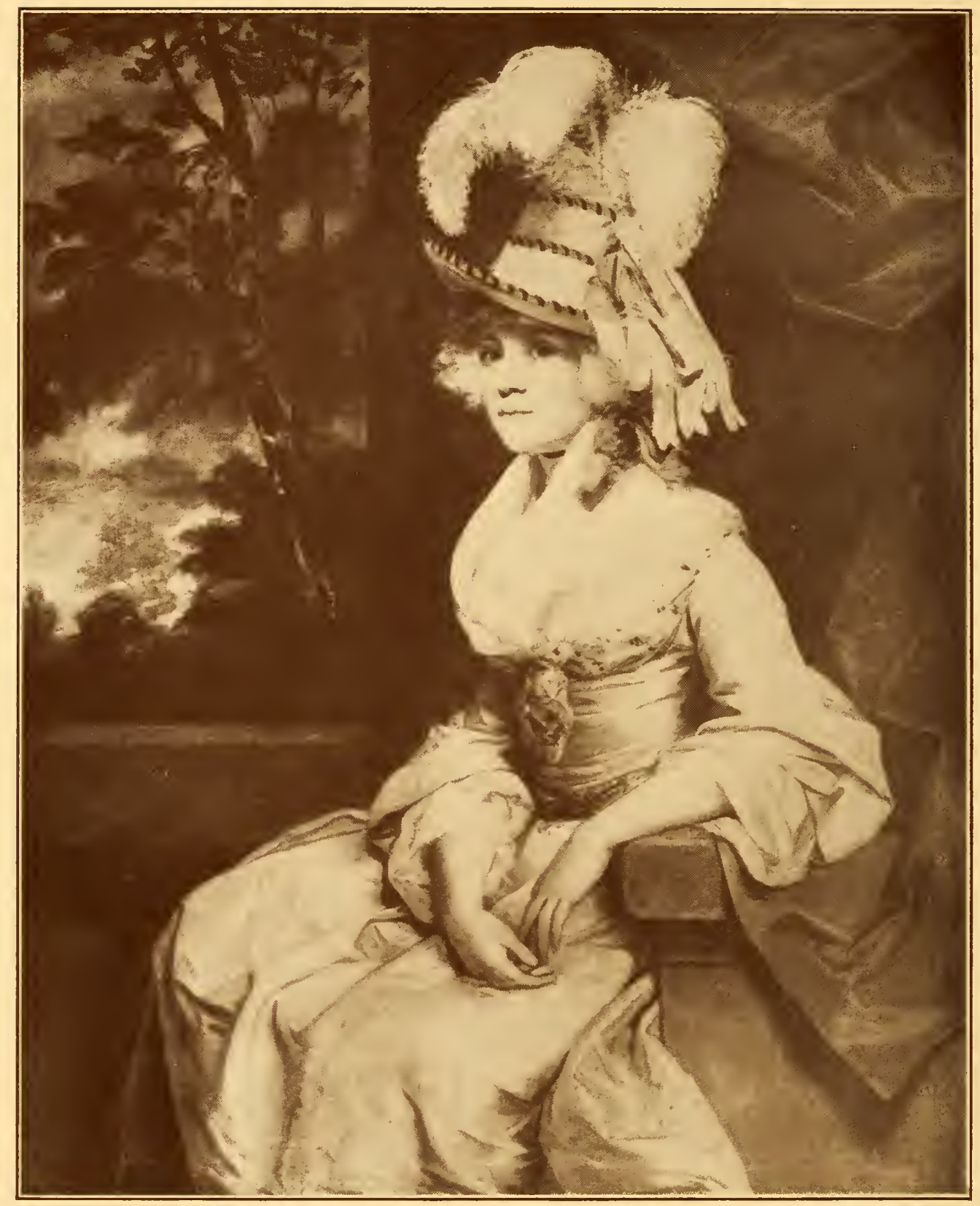


SIR JOSHUA REYNOLDS, P.R.A.

\section{( I723-I792)}

\section{LADY ELIZABETH TAYLOR}

Canvas, 49\%2 inches by 40 inches

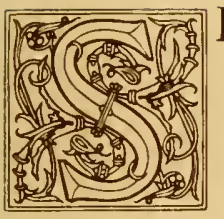

EATED, turned to the right, wearing a white hat trimmed with black and yellow twisted velvet cord, three white ostrich feathers, and pale blue ribbon fastened at the side, cockade fashion; white dress, white fichu, and a black velvet ribbon just showing at the throat. Powdered hair, falling in ringlets over the shoulders. Her left elbow is resting on a pedestal, with both hands in her lap. The background consists of a pale green curtain, with a landscape to the right.

Elizabeth Gooden Houghton, daughter of Phillip Houghton, of Jamaica, married December i 7 th, I 778 , John Taylor, Esq., F.R.S., of Nysson Hall, in the same island, who was created a baronet in 1780 .

This picture was entered to be sold in Phillips' Catalogue of July 20th, I 835 , lot I 42 , and purchased anonymously; it afterwards became the property of Monsieur Maurice Kann, Paris.

It is mentioned in Graves and Cronin's "A History of the Works of Sir Joshua Reynolds," and illustrated in "Les Arts," April, i 909.

It has been engraved by Henry Chiffer and exhibited at the Boston Museum of Fine Arts, I9Io. 


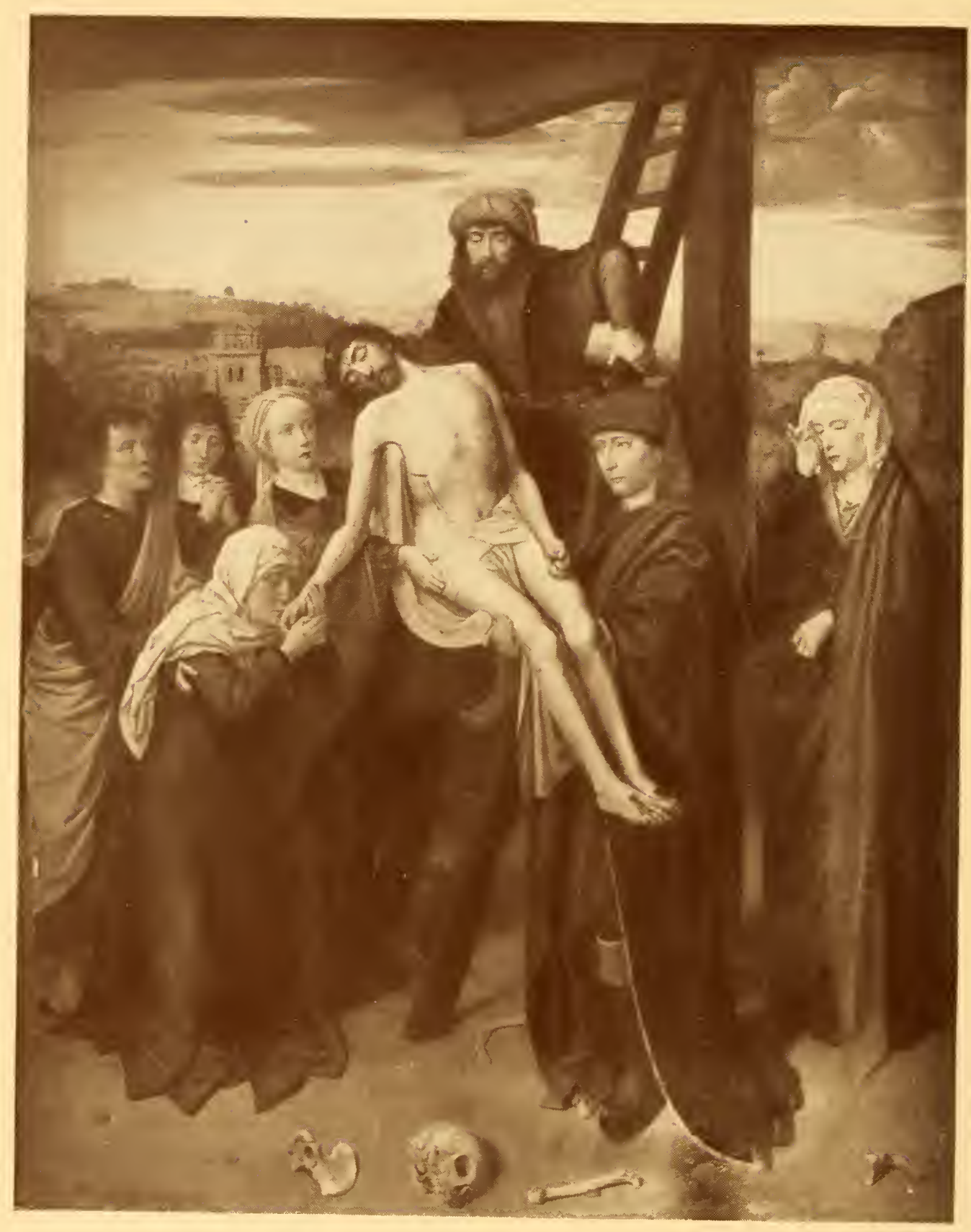




\section{GERARD DAVID}

\section{( 1450 to $1460-1523$ )}

\section{DESCENT FROM THE CROSS}

Canvas, $45 \frac{1}{2}$ inches by 56 inches.

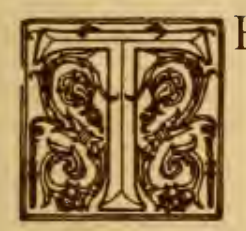

HIS interesting Flemish primitive bears unmistakable evidence of being entirely in the hand of Gerard David, who painted the same subject at least thrice.

There is a somewhat similar picture in the Carvallo Collection in Paris, and one in the Royal Uffizi Gallery, at Florence.

Dr. Bodenhausen writes that "the picture is without any doubt a masterpiece, entirely in the master's own hand," and he draws attention to certain similarities, even in details, existing in this painting and those in Europe.

From the Collection of the Kings of Holland.

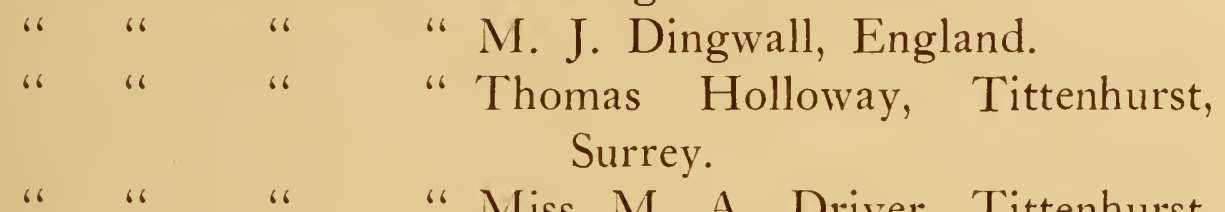
Sunninghill.

Exhibited, Manchester Art Treasures, i 857 , No. 43 O.

" Royal Academy, London, "Old Masters," i 9 r 2, No. 47.

“ M. Knoedler \& Co., Paris, "Old Masters," I9 3 3, No. 36 .

Mentioned in the "Gerard David und seine Schule" by Bodenhausen, I905, pp. I96-197.

Reproduced on p. I97 of the same work. 


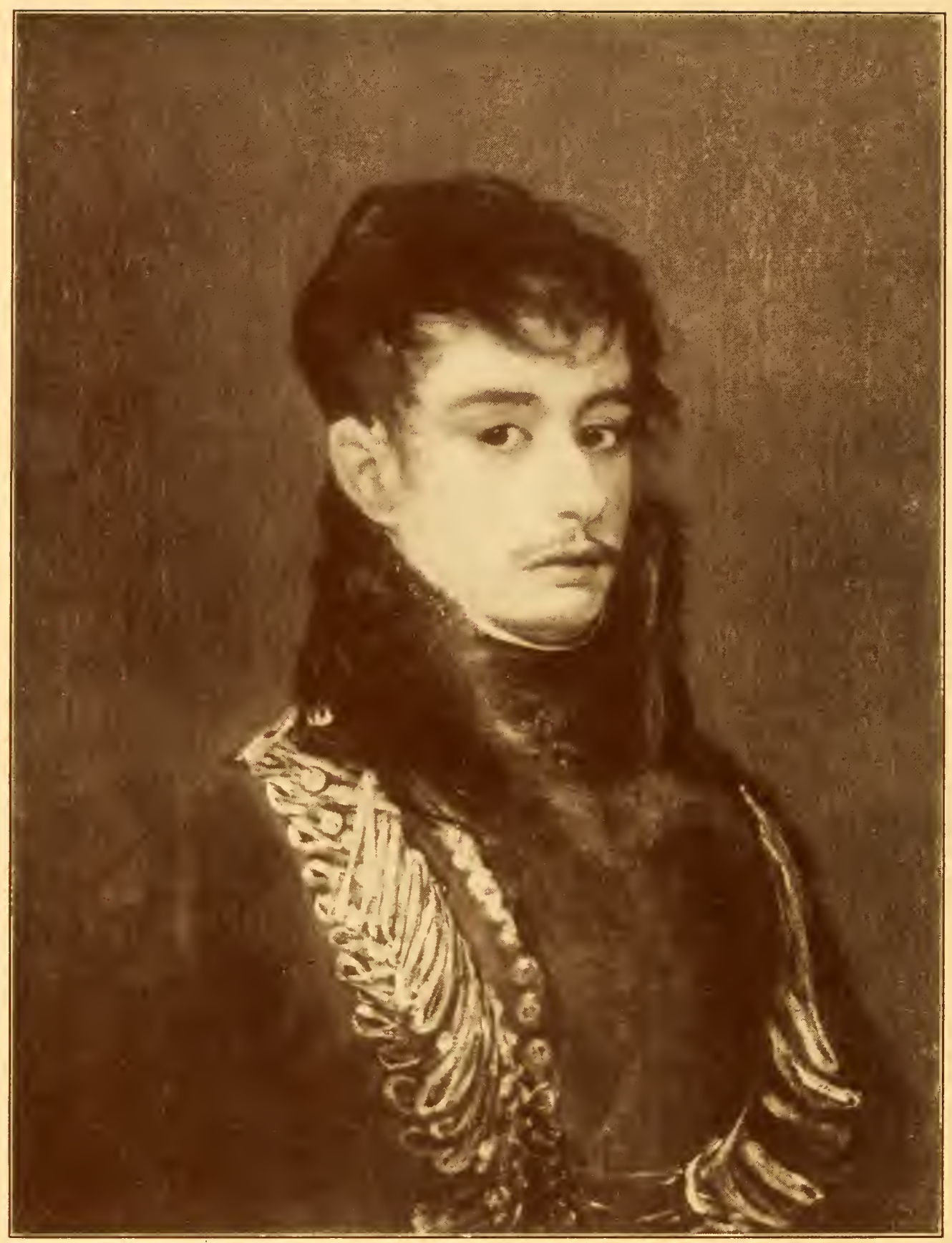




\section{FRANCISCO GOYA}

\section{( $1746-1828$ ) \\ EL CONDE DE TEBA \\ Canzas, 233/4 inches by $191 / 4$ inches}

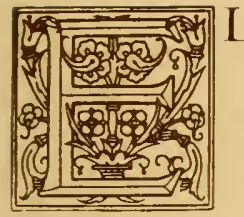

L CONDE DE TEBA, who is represented by this portrait, was born about $\mathrm{I}_{7} 85$. He was the second son of Count de Montijo, which title he inherited after his brother's death. He offered his sword to Napoleon, thinking him the regenerator of Spain, and it was at this time, I 810 , that Goya, attracted by this sensitive and high-strung young nobleman, painted his portrait. At Salamanca he was shot in the eye and his leg was broken by a cannon ball. In I 8 I 4 at Buttes-Chaumont he was again wounded. St. Amand, in his book, "Louis Napoleon and Mlle. de Montijo," says: "Invaded France was not defended more valiantly by any Frenchman than by this Spaniard. He fired the last discharge of cannon which delayed for a day the entry of the allies into Paris." In I 8 I 6 he married Maria Manuela de Kirkpatrick y Grivegnée. Her genealogy is clearly established in the notes left by her cousin, Ferdinand Lesseps, the illustrious creator of the Suez Canal. She was the daughter of Baron William Kirkpatrick, of Closeburn, Scotland, who was forced to leave his native country because of his close affiliation and devotion to the Stuarts. Their first daughter was Françoise, born in I 825 , and Eugénie came the following year. Françoise in I 844 became the wife of the most powerful and richest nobleman in Spain, the Duke of Alba, twelve times grandee of Spain. Eugénie, in I 853, married Napoleon III. and thus became the Empress of the French.

Writing of this portrait Royal Cortissoz says:- "As a study of character it is one of those rare paintings in which Goya forgot to be cynical and scornful. This portrait is a flawless gem."

It comes from the collection of José Lazaro Galdeano. 


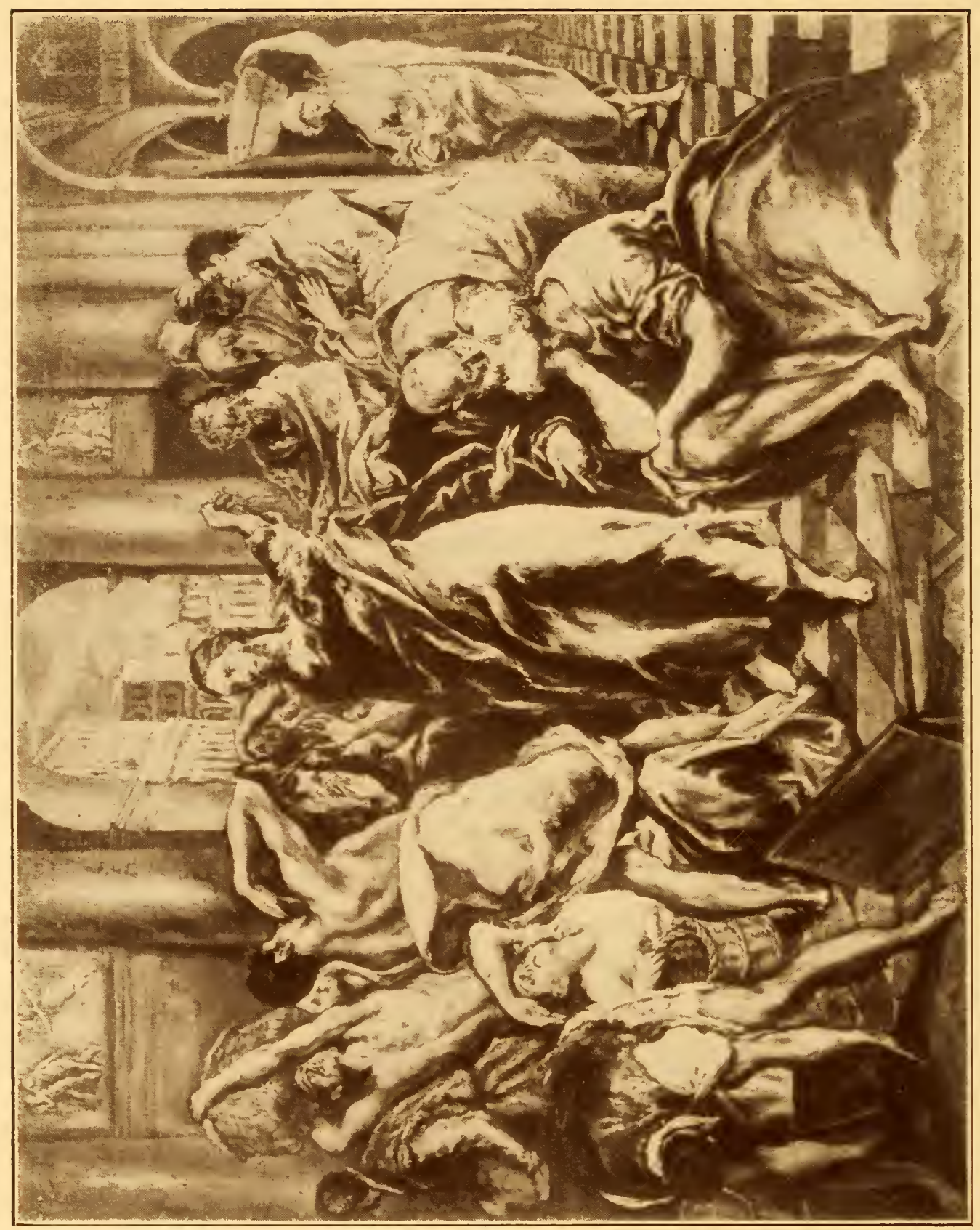




\section{"EL GRECO"}

(Dominico Theotocopuli)

$$
\text { ( I 545?-I6 14?) }
$$

\section{THE PURIFICATION OF THE TEMPLE}

\section{Canvas, 20 inches by 16 inches}

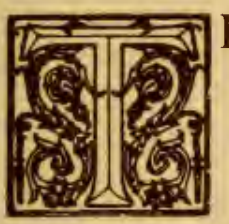

HE Saviour, with raised right arm, and attired in crimson robe and green mantle, stands in the centre of the picture. To the left, the traders in the other figures, probably the disciples, in yellow, red, light-blue and green robes. Through an arch in the centre is seen a street with white buildings, blue sky and white clouds.

Painted between I 577 and I 579 .

In a recent work on "El Greco" by A. F. Calvert and C. G. Hartley, the authors thus speak of this painting:

"The quality of the execution of this singular work, and the analogy it offers with pictures painted much later, places it in a special position as a work of transition that links the Italian epoch of youth with the Spanish epoch of fulfilment. There is no change in the actual composition of the picture; the scene of the background is the same; the male figures are identical, even their attitudes are repeated. Yet the difference between this work and the London pictures is as great as it well can be. The subject has become dramatic. The action has been concentrated and simplified; and all the trifling accessories have been removed. The figures have gained in individuality-become alive; and a splendid idea of movement is gained. Tradition here gives place to personality. We have in this picture the seal of El Greco's originality; he has liberated himself from any youthful imitations of the Renaissance masters. Tintoretto alone can have been remembered in painting this animated 'Purification of the Temple.' '

The painting is illustrated in the same volume, plate $2 \mathrm{I}$, and has been reproduced in several other books on Spanish art. It has been exhibited in London and in Madrid. 


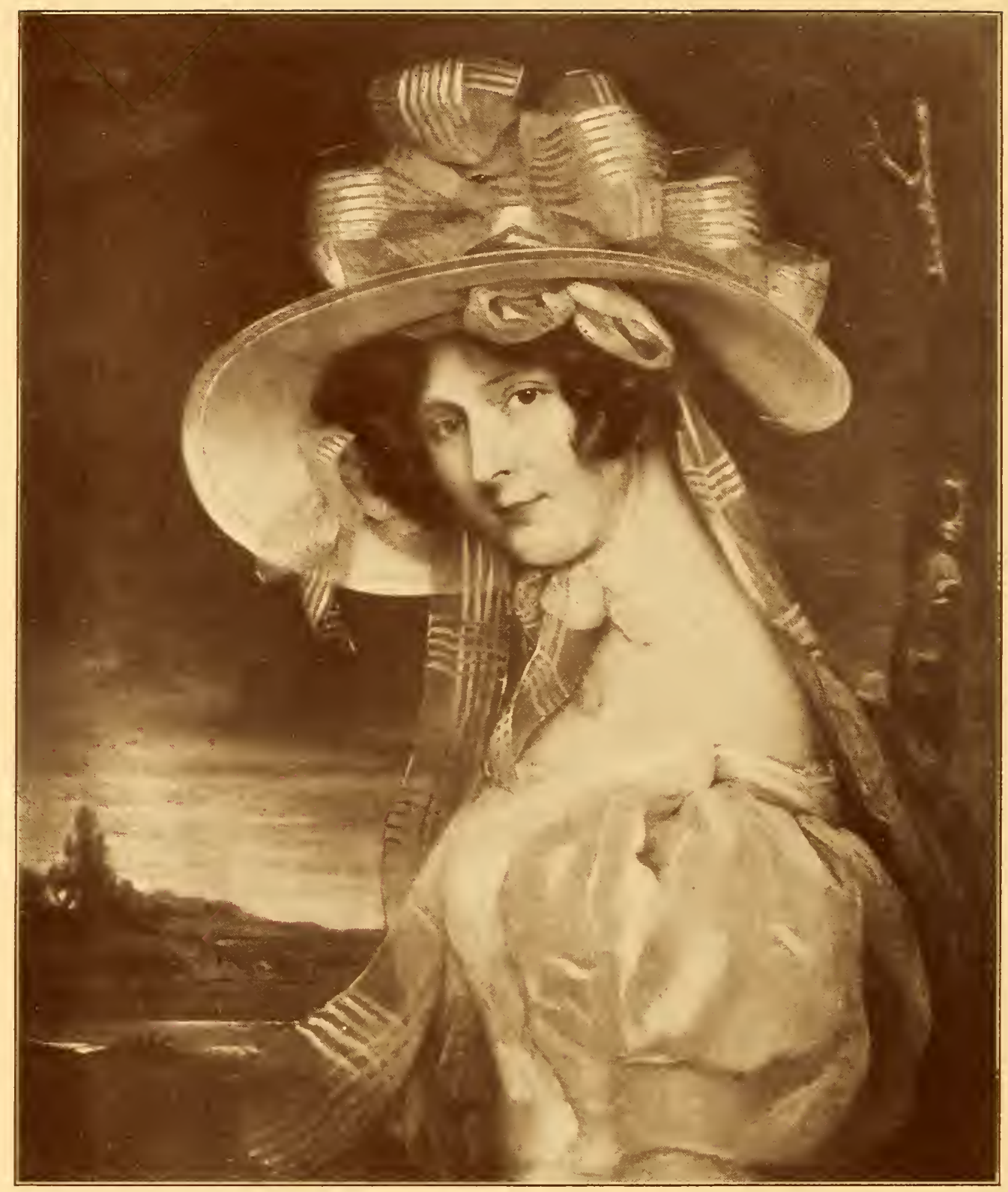


SIR THOMAS LAWRENCE, P.R.A.

$$
\text { ( с 769-1830) }
$$

\section{LA MARQUISE DU BLAISEL}

Canvas, 25 inches by 30 inches

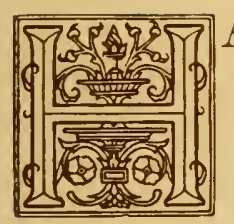

ALF-LENGTH, nearly full face, dressed in low neck gown of white satin. Large yellow picture hat tied under chin, two yellow streamers hanging either side, blue scarf over right shoulder. To the left a glimpse of landscape.

This portrait was painted by Lawrence in Paris, in I 825 , where he had gone to execute a commission from George IV. to paint the French King, Charles X. He had a painting-room in the Tuileries. He also painted the Duchess de Berri; and the whole royal family showered attentions upon him, the Duke of Orleans, afterward Louis Philippe, among the rest. Besides the usual recognitions, the King presented the painter with a set of Sèvres porcelains, which he afterward left to the Royal Academy.

Mentioned in Sir Walter Armstrong's book on Sir Thomas Lawrence, p. I I 4 .

The house of du Blaisel was established before the reign of Louis IX., and is one of the most ancient in Picardy. It originated with the ancient dukes of Brabant. Daniel du Blaisel was killed at the battle of Crécy in the army of the Puke of Brabant, and is mentioned in Froissart. Wm. du Blaisel was slain at Poictiers; John was killed at Agincourt; Charles at the siege of La Rochelle, and Barthélemy in the Fronde. By alliance in 1467 , the family descended on the distaff side from Louis IV., King of France.

A branch of the family received the title of marquis in the person of Louis du Blaisel, camp marshal, lieutenant of the royal gardes du corps by letters patent dated June 28 th, 1780 .

The du Blaisels were also marquises of the Holy Roman Empire since I 7 I 4. 


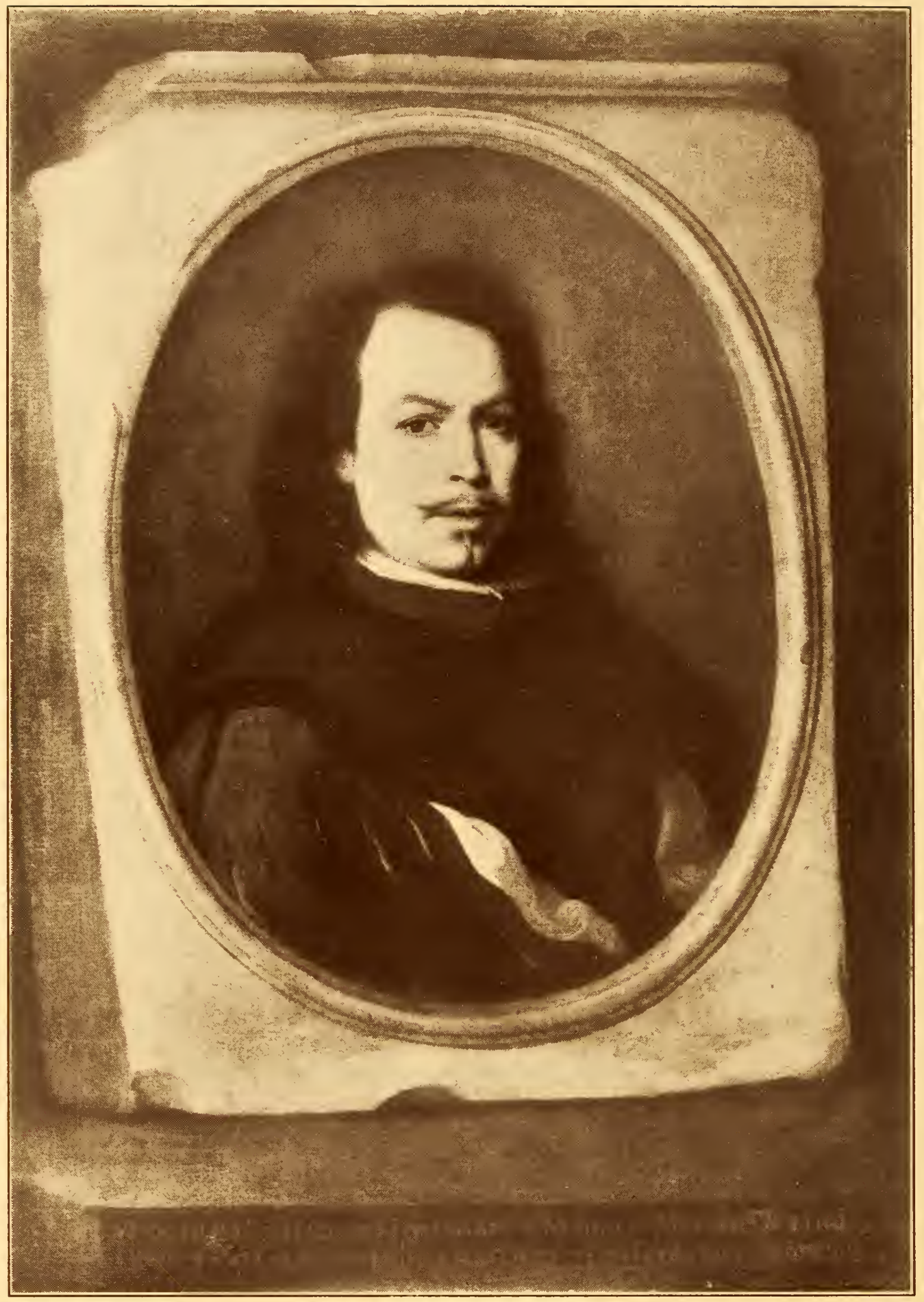




\section{PORTRAIT OF HIMSELF}

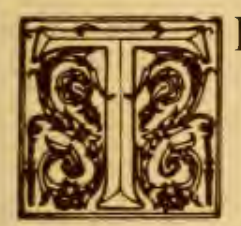

HE painter is represented about fifty (?) years of age with long hair falling on both shoulders, slight mustache and chin tuft, close-fitting black doublet with slashed sleeves and a golilla or narrow stiff linen collar. Bust, without hands, in an oval, as if painted on a block of marble standing on another block, which is inscribed (in another hand) 'Vera efigies Bartholomæi Stephani a Morillo Maximi pictoris Hispali Nati anno I6 I 8, obiit anno I682 Tertia die Mensis Aprilis.' "-Charles B. Curtis, Velasquez and Murillo, p. 295.

From the collection of D. Bernardo Iriarte, Madrid.

danos.

" " " D. Francisco de la Barrera Engui-

From the collection of Julian Williams, who sold it to King Louis Philippe. It was exhibited in the Spanish Gallery. Louvre, No. I 82. After the death of Louis Philippe it was sold to John Nieuwenhuys, who sold it to Baron Sellière, Paris, who left it to his daughter, the Princess de Sagan.

This famous portrait is one of the items in Murillo's will. It was left to his son, Don Gaspar Murillo, and is mentioned by Palomino as being in Don Gaspar's possession. Its identity is assured by the "golilla" or stiff linen collar, referred to by Palomino. Cean Bermudez (Carta 104) also refers to the portrait "with the golilla" as appearing among the finished pictures enumerated in Murillo's will. Stirling, in his "Annals," ii., 897-8, refers to "the picture which afterwards came into the possession of Don Bernardo Iriarte" as probably identical with that which, "sold by Don Julian Williams to the King of the French, is now one of the gems of the Louvre." 


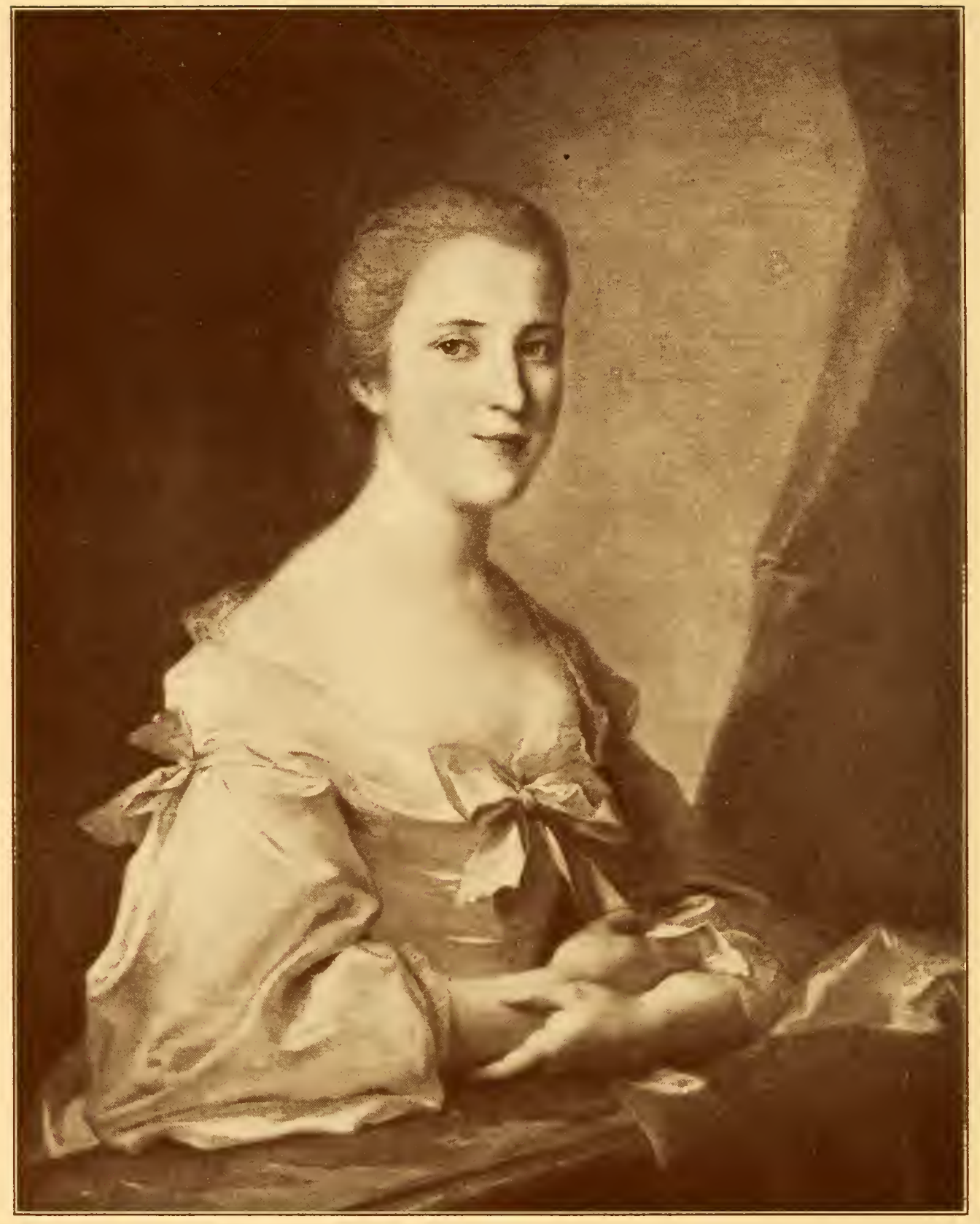


JEAN MARC NATTIER

( I685-I766)

THE HON. ELIZABETH HAMILTON

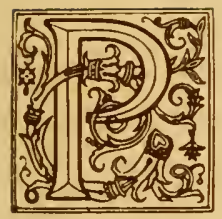

ORTRAIT of the Hon. Elizabeth Hamilton, eldest daughter of Lord Archibald Hamilton, married to the Earl of Warwick, I742. This portrait belonged to Charles Greville, the friend of Emma Hart (Lady Hamilton).

"Francis, first Earl Brooke, and first Earl of Warwick, K.T., born I I I9, succeeded to the barony in 1727 , and was created Earl Brooke in I 746; and the title of Earl Warwick of Warwick Castle, becoming extinct by the death of Edward Rich, Earl of Warwick and Holland, 7th Sept., I759, his majesty was pleased to add the dignity of Earl of Warwick to his lordship's other honors, by patent dated 3oth Nov. in the same year. His lordship married I6th May, I 742, Elizabeth, eldest daughter of Lord Archibald Hamilton, by whom he had three sons."-Burke's Peerage.

She also bore him five daughters. The eldest son, George, born September, I746, at Warwick Castle ("the King doing him the honor of standing godfather by Lord Conway, his proxy") married Henrietta Vernon, the Lady Warwick of the full-length Romney in this Collection. The Countess of this portrait, after her husband's death, married General Robert Clark. She died in April, I 800 , in her 8oth year, and was buried in Westminster Abbey.

In a letter of Lady Dalkeith, dated August 20, I 765 , quoted in Complete Peerage, she says; "Lord! Lord! What strange creatures there are among us women. Lady Warwick has come to England, and was refused admittance at her lord's house in Hill Street, and has taken lodgings in Kensington." 


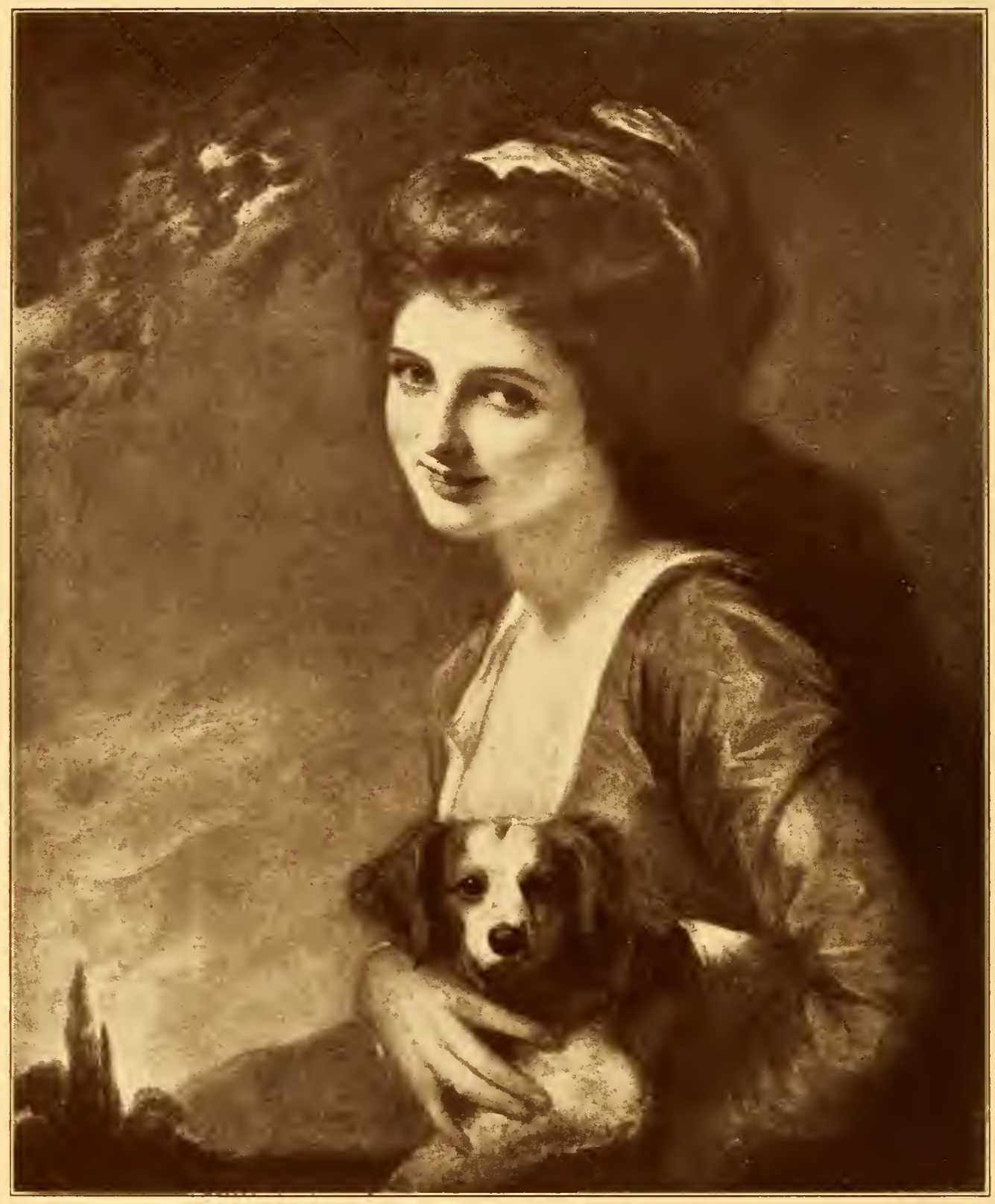




\section{GEORGE ROMNEY}

\section{( I734-1802) \\ LADY HAMILTON AS "NATURE"}

Canvas, 25 inches by 30 inches

TS ALF-LENGTH, almost full face, dressed in a low neck gown. In her arms she holds a Blenheim 2. On spaniel. On her head is a colored scarf of gauzy 25 material. Her hair hangs loose down her back. Lips parted in a smile. Landscape on the left.

In the Rev. John Romney's book on the artist, it is stated that it was in 1782 that Lady Hamilton, under the name of Mrs. Hart, first sat to Romney. "She was brought by the Hon. Charles Greville to sit for a three-quarter portrait. It was that beautiful one so full of naïveté, in which she is represented with a little spaniel lap dog under her arm."

In 1784 it was engraved in mezzotint by J. R. Smith, entitled "Nature," and published with these lines:

"Flush'd by the Spirit of the Genial Year,

Her lips blush deeper sweets, the breath of Youth;

The shining moisture swells into her eyes In brighter glow, her wishing bosom heaves With palpitations wild."

Numerous other engravings of it have been made. Indeed, it is the most popular of all Romney pictures, as well as the most attractive portrait of Lady Hamilton. An enamel "after the original by Romney" by J. Lee, was exhibited at the Royal Academy of 1825 .

Lady Hamilton died at Calais in I 8 I 5. 



\section{Supplemental List of Paintings}

Corot, Jean Baptiste, Ville d'Avray

L'Étang

Le Matin, Lac de Garde

Daubigny, Charles François,

Les Laveuses

Dieppe

Dégas, Edgard H. G., The Rehearsal

Diaz de la Peña, N. V., La Mare Aux Vipers

Love's Caresses

La Plaine

Les Baigneuses

Dupré, Jules,

La Rivière

Goya y Lucientes, F.,

Señora Donna Maria Martinez Da Puga

Manet, Edouard,

Combat de Taureaux

Maris, Jacor,

Amsterdam

Maris, Willem,

Cattle at Pasture

Metzu, Gabriel,

Lady in Blue

Monet, Claude,

Bords de la Seine à Lavacour

Rénoir, Firmin Auguste, Woman and Children

Rico, Martin,

Fishermen's Houses, Venice

Rousseau, Pierre Étienne Theodore,

Dessous de Bois

Village of Becquigny

Ruysdael, Solomor van, Landscape with River

Troyon, Constant, Paysage

Pasture in Normandy

Whistler, James Abbott McNeill,

Portrait of Rosa Corder

Count Robert de Montesquiou-Fézénac

The Ocean

ZieM, FÉLIX,

French Garden at Venice 





\section{DATE USED}

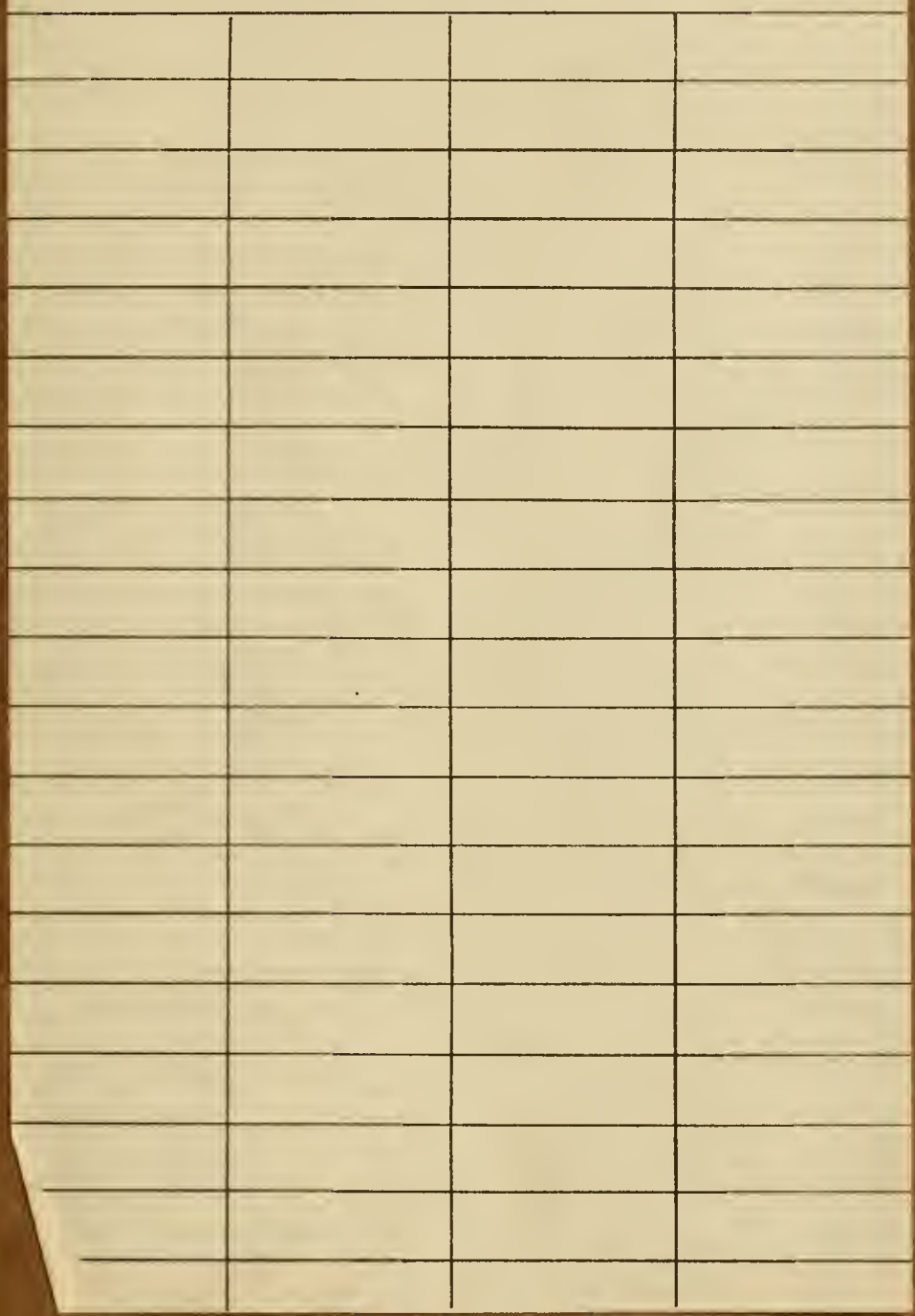


